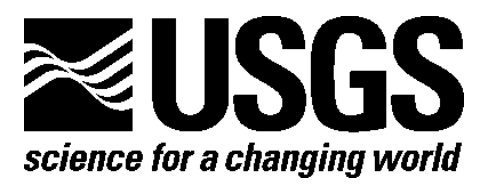

\title{
Geochemical Data for Core and Bottom-Sediment Samples Collected in 2007 from Grand Lake 0' the Cherokees, Northeast Oklahoma
}

By David L. Fey, Mark F. Becker, and Kathleen S. Smith

Open-File Report 2010-1298

U.S. Department of the Interior

U.S. Geological Survey 


\section{U.S. Department of the Interior \\ KEN SALAZAR, Secretary}

\section{U.S. Geological Survey \\ Marcia K. McNutt, Director}

U.S. Geological Survey, Reston, Virginia: 2010

For product and ordering information:

World Wide Web: http://www.usgs.gov/pubprod

Telephone: 1-888-ASK-USGS

For more information on the USGS-the Federal source for science about the Earth,

its natural and living resources, natural hazards, and the environment:

World Wide Web: http://www.usgs.gov

Telephone: 1-888-ASK-USGS

Suggested citation:

Fey, D.L., Becker, M.F., and Smith, K.S., Geochemical data for core and bottom-sediment samples collected in 2007

from Grand Lake O' the Cherokees, northeast Oklahoma: U.S. Geological Survey Open-File Report 2010-1298, 70 p.

Any use of trade, product, or firm names is for descriptive purposes only and does not imply endorsement by the U.S. Government.

Although this report is in the public domain, permission must be secured from the individual copyright owners to reproduce any copyrighted material contained within this report. 


\section{Contents}

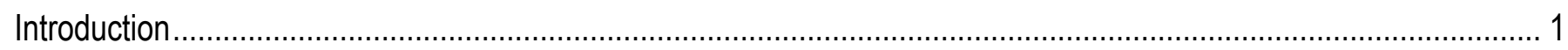

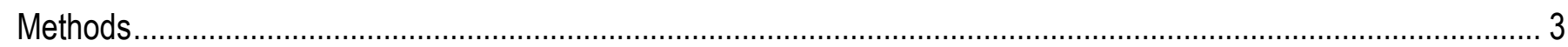

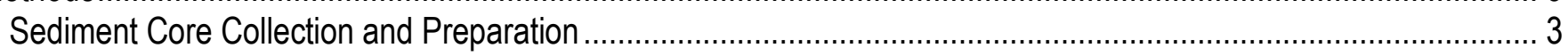

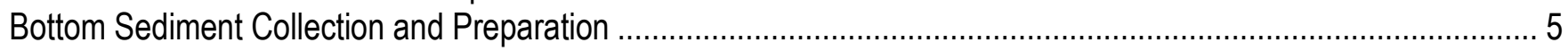

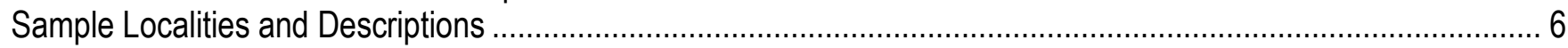

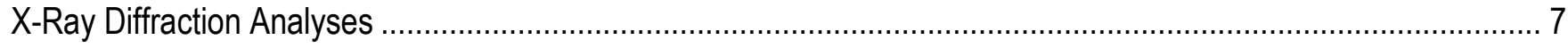

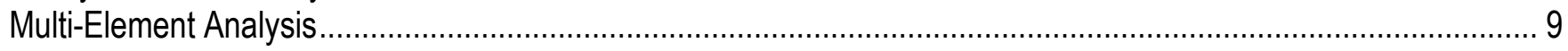

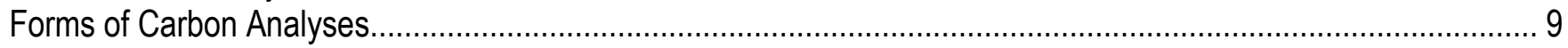

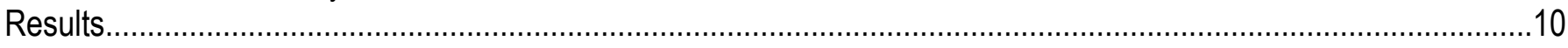

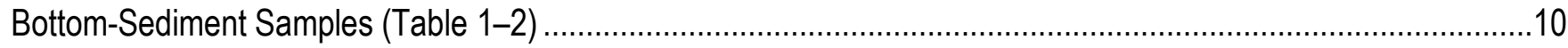

Core GLOC-9 Elk River Arm of Grand Lake O' the Cherokees (Table 1-3) ......................................................12

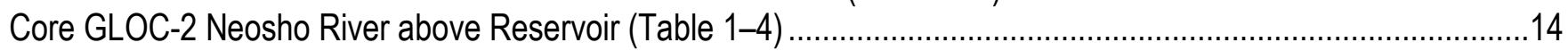

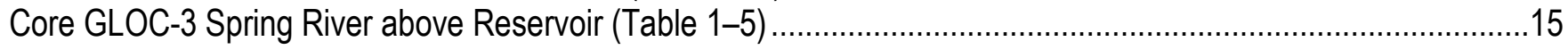

Core GLOC-7 Grand Lake O' the Cherokees Reservoir (Table 1-6) ...............................................................16

Core GLOC-8 Confluence of Neosho and Spring Rivers (Table 1-7) ............................................................17

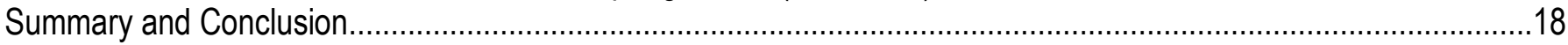

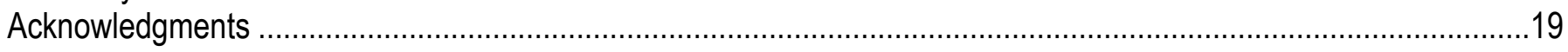

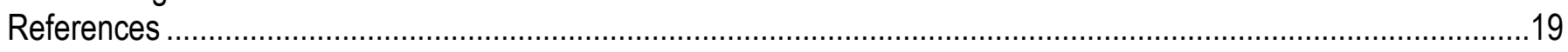

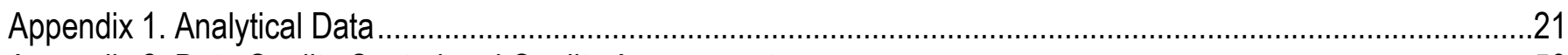

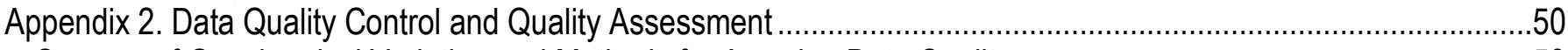

Sources of Geochemical Variation and Methods for Assuring Data Quality.......................................................50

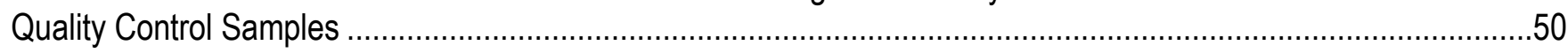

Quality Assurance/Quality Control Measurement ....................................................................................51

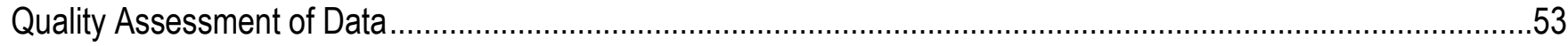

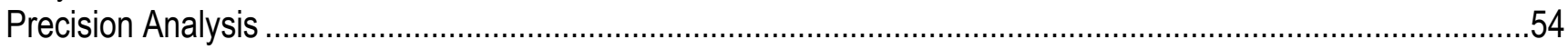

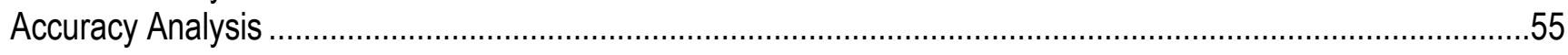

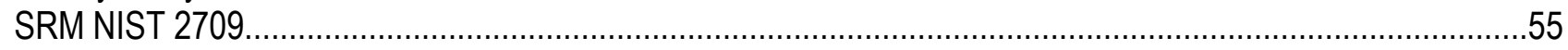

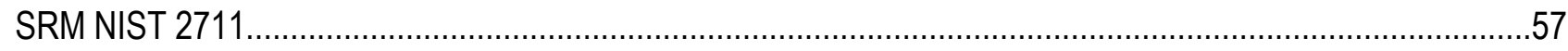

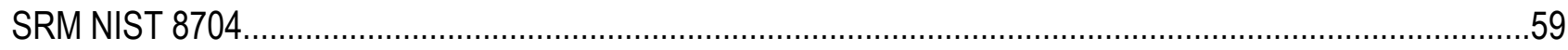

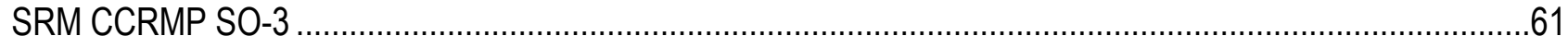

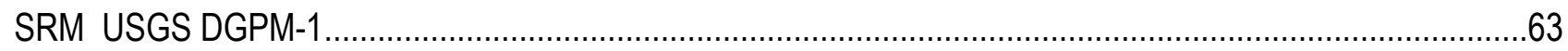

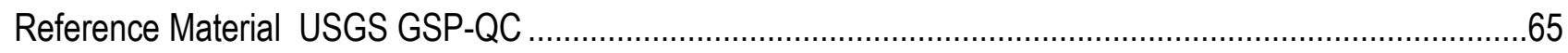

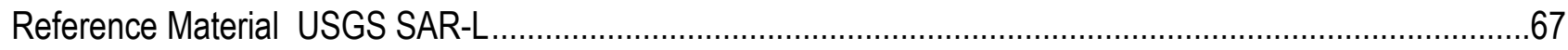

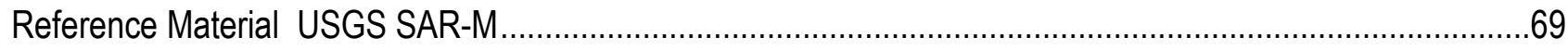

\section{Figures}

1. Location map for samples taken in the Grand Lake $O^{\prime}$ the Cherokees area in northeast Oklahoma .............. 2

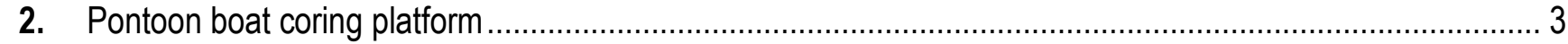

3. Close-up view of mechanical vibrator attached to core barrel......................................................... 4

4. Simple gravity corer used to collect reservoir bottom-sediment samples ............................................... 5

1-1. Concentration versus depth profile for cadmium, lead, and zinc for background core GLOC-9 ..................13

1-2. Concentration versus depth profile for cadmium, lead, and zinc for core GLOC-2 .................................14 
1-3. Concentration versus depth profile for cadmium, lead, and zinc for core GLOC-3 ….................................15

1-4. Concentration versus depth profile for cadmium, lead, and zinc for core GLOC-7 ...................................16

1-5. Concentration versus depth profile for cadmium, lead, and zinc for core GLOC-8 ..................................17

2-1. Precision plot for ICP-AES/MS and carbon analyses based on three estimates of variance ........................54

2-2. Accuracy plot for ICP-AES/MS and carbon analyses for standard reference material NIST 2709................55

2-3. Accuracy plot for ICP-AES/MS and carbon analyses for standard reference material NIST 2711 ................57

2-4. Accuracy plot for ICP-AES/MS and carbon analyses for standard reference material NIST 8704 ................59

2-5. Accuracy plot for ICP-AES/MS and carbon analyses for standard reference material CCRMP SO-3...........61

2-6. Accuracy plot for ICP-AES/MS and carbon analyses for standard reference material USGS DGPM-1 ........63

2-7. Accuracy plot for ICP-AES/MS and carbon analyses for reference material USGS GSP-QC.......................65

2-8. Accuracy plot for ICP-AES/MS and carbon analyses for refernce material USGS SAR-L ............................67

2-9. Accuracy plot for ICP-AES/MS and carbon analyses for refernce material USGS SAR-M ..........................69

\section{Tables}

1. Field numbers, sample localities, dates, and site descriptions for core and reservoir bottom-sediment samples taken from Grand Lake O' the Cherokees, September 2007

2. Field numbers, water depths, and visual sample descriptions for core and reservoir bottom-sediment

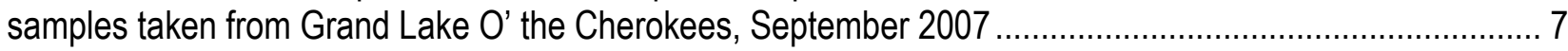

3. Field numbers and mineralogy by X-ray diffraction for subsamples from cores GLOC-2, GLOC-3, and

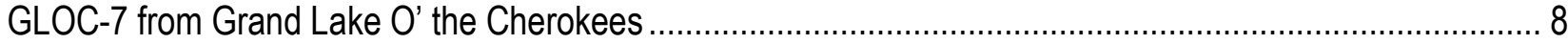

4. Crustal abundance values for elements analyzed in this report ...........................................................10

1-1. Elements analyzed, instrument used, reporting limits, and mean of eight procedure blanks for four-acid

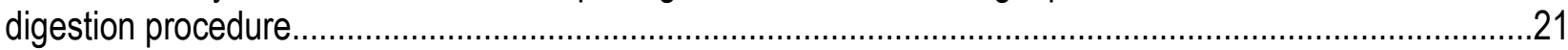

1-2. Grand Lake O' the Cherokees bottom-sediment sample analyses .........................................................22

1-3. Core sediment background sample analyses for GLOC-9, Elk River arm of Grand Lake O' the Cherokees.

1-4. Core sediment sample analyses for GLOC-2, Neosho River upstream from Grand Lake O' the Cherokees.

1-5. Core sediment sample analyses for GLOC-3, Spring River upstream from Grand Lake O' the Cherokees...40

1-6. Core sediment sample analyses for GLOC-7, Grand Lake O' the Cherokees 4 kilometers downstream from Highway 2 bridge

1-7. Core sediment sample analyses for GLOC-8, Grand Lake O' the Cherokees at confluence of Spring and Neosho Rivers.

2-1. Summary statistics for assessing analytical precision for carbonate carbon, total carbon, and 26 elements by ICP-AES/MS

2-2. Summary statistics for assessing analytical variation and accuracy for the standard reference material NIST 2709......

2-3. Summary statistics for assessing analytical variation and accuracy for the standard reference material NIST 2711

2-4. Summary statistics for assessing analytical variation and accuracy for the standard reference material NIST 8704

2-5. Summary statistics for assessing analytical variation and accuracy for the standard reference material CCRMP SO-3

2-6. Summary statistics for assessing analytical variation and accuracy for the standard reference material USGS DGPM-1

2-7. Summary statistics for assessing analytical variation and accuracy for the reference material USGS GSP-QC. 
2-8. Summary statistics for assessing analytical variation and accuracy for the reference material USGS SAR-L

2-9. Summary statistics for assessing analytical variation and accuracy for the reference material USGS SAR-M 


\section{Conversion Factors}

Inch/Pound to SI

\begin{tabular}{lcl}
\hline \multicolumn{1}{c}{ Multiply } & \multicolumn{1}{c}{ By } & \multicolumn{1}{c}{ To obtain } \\
\hline inch (in) & Length & \\
inch (in) & 2.54 & centimeter $(\mathrm{cm})$ \\
foot (ft) & 0.0254 & meter $(\mathrm{m})$ \\
mile (mi) & 0.3048 & meter $(\mathrm{m})$ \\
\hline & 1.609 & kilometer $(\mathrm{km})$ \\
\hline square mile $\left(\mathrm{mi}^{2}\right)$ & Area & \\
\hline & 2.590 & square kilometer $\left(\mathrm{km}^{2}\right)$ \\
\hline ounce, avoirdupois (oz) & Mass & \\
pound, avoirdupois $(\mathrm{lb})$ & 28.35 & gram $(\mathrm{g})$ \\
ton, short $(2,000 \mathrm{lb})$ & 453.6 & gram $(\mathrm{g})$ \\
\hline
\end{tabular}

SI to Inch/Pound

\begin{tabular}{|c|c|c|}
\hline Multiply & By & To obtain \\
\hline \multicolumn{3}{|c|}{ Length } \\
\hline centimeter $(\mathrm{cm})$ & 0.3937 & inch (in) \\
\hline meter $(\mathrm{m})$ & 39.37 & inch (in) \\
\hline meter $(\mathrm{m})$ & 3.281 & foot $(\mathrm{ft})$ \\
\hline kilometer $(\mathrm{km})$ & 0.6214 & mile $(\mathrm{mi})$ \\
\hline \multicolumn{3}{|c|}{ Area } \\
\hline square kilometer $\left(\mathrm{km}^{2}\right)$ & 0.3861 & square mile $\left(\mathrm{mi}^{2}\right)$ \\
\hline \multicolumn{3}{|c|}{ Mass } \\
\hline $\operatorname{gram}(\mathrm{g})$ & 0.03527 & ounce, avoirdupois (oz) \\
\hline $\operatorname{gram}(\mathrm{g})$ & 0.002205 & pound avoirdupois (lb) \\
\hline megagram (Mg) & 1.102 & ton, short $(2,000 \mathrm{lb})$ \\
\hline
\end{tabular}

Temperature in degrees Celsius $\left({ }^{\circ} \mathrm{C}\right)$ may be converted to degrees Fahrenheit $\left({ }^{\circ} \mathrm{F}\right)$ as follows:

${ }^{\circ} \mathrm{F}=\left(1.8 \mathrm{x}^{\circ} \mathrm{C}\right)+32$

Temperature in degrees Fahrenheit $\left({ }^{\circ} \mathrm{F}\right)$ may be converted to degrees Celsius $\left({ }^{\circ} \mathrm{C}\right)$ as follows:

${ }^{\circ} \mathrm{C}=\left({ }^{\circ} \mathrm{F}-32\right) / 1.8$

Vertical coordinate information is referenced to the World Geodetic System of 1984 (WGS84).

Horizontal coordinate information is referenced to the World Geodetic System of 1984 (WGS84).

Altitude, as used in this report, refers to distance above the vertical datum.

Concentrations of chemical constituents in solid samples are given in either percent (\%), parts per million (ppm), or parts per billion (ppb). 


\title{
Geochemical Data for Core and Bottom-Sediment Samples Collected in 2007 from Grand Lake O' the Cherokees, Northeast Oklahoma
}

\author{
By David L. Fey, Mark F. Becker, and Kathleen S. Smith
}

\section{Introduction}

The Tri-State Mining District, a Mississippi Valley-type (MVT) zinc-lead district, covers an area of about 1,200 square miles $\left(\mathrm{mi}^{2}\right)\left(3,108\right.$ square kilometers $\left.\left[\mathrm{km}^{2}\right]\right)$ in northeast Oklahoma, southwest Missouri, and southeast Kansas. The district was active from about 1850 to 1970 and during much of this time was the largest producer of zinc $(\mathrm{Zn})$ and lead $(\mathrm{Pb})$ ore in the world. Over the lifespan of the district, more than 4,000 mines produced 23 million tons of zinc concentrate and 4 million tons of lead concentrate (Brosius and Sawin, 2001). Gibson (1982) estimated the district total production at 8.8 million tons zinc and 1.7 million tons lead.

A consequence of 120 years of mining activity in the district was the distribution on the surface of between 165 and 300 million tons of processed mine tailings (chat), the majority of which has been used as road aggregate or has eroded into nearby drainages. The U.S. Army Corps of Engineers has estimated that 75 million tons of chat remain in the district (Andrews and others, 2009; State of Oklahoma, 2000). This material contains elevated concentrations of cadmium (Cd), lead, and zinc (Andrews and others, 2009; Juracek and Becker, 2009), which can be transported by water and wind into nearby receiving streams, ponds, and rivers. Seepage from flooded mine workings and the leaching of chat material can also transport dissolved metals to local surface water (Andrews and others, 2009). The metals are transported either as dissolved aqueous species downstream (Carroll and others, 1998), as mineral grains entrained in bottom sediment, or through sorbtion to colloidal material or clay that becomes incorporated into the bottom sediment of streams, rivers, lakes, and reservoirs (Andrews and others, 2009). Accumulation of these metals in sediments downstream from the district is recognized as a potential hazard to aquatic life (Pope, 2005; Andrews and others, 2009).

Grand Lake O' the Cherokees is a large reservoir in northeast Oklahoma, below the confluence of the Neosho and Spring Rivers, both of which drain the Tri-State District to the north (fig. 1). The reservoir was constructed in 1940 by the completion of the Pensacola Dam by the Grand River Dam Authority. Concerns of sediment quality and the possibility of human exposure to cadmium and lead through eating fish have led to several studies of the sediments in the Tri-State District:

- bottom sediment of Grand Lake O’ the Cherokees: Juracek and Becker (2009);

- stream sediment in the Oklahoma part of the Tri-State District: Andrews and others (2009);

- Empire Lake, Kansas: Juracek (2006);

- stream sediment in the Kansas part of Tri-State district: Pope (2005);

- stream sediment in the Tar Creek Basin: Parkhurst and others (1988); and

- stream sediment in the Tri-State District: Carroll and others (1998).

Other references regarding the Tar Creek and Picher areas include Erickson and others (1988), Parkhurst (1987, 1988), Parkhurst and others (1988), and Smith and others (1988). 


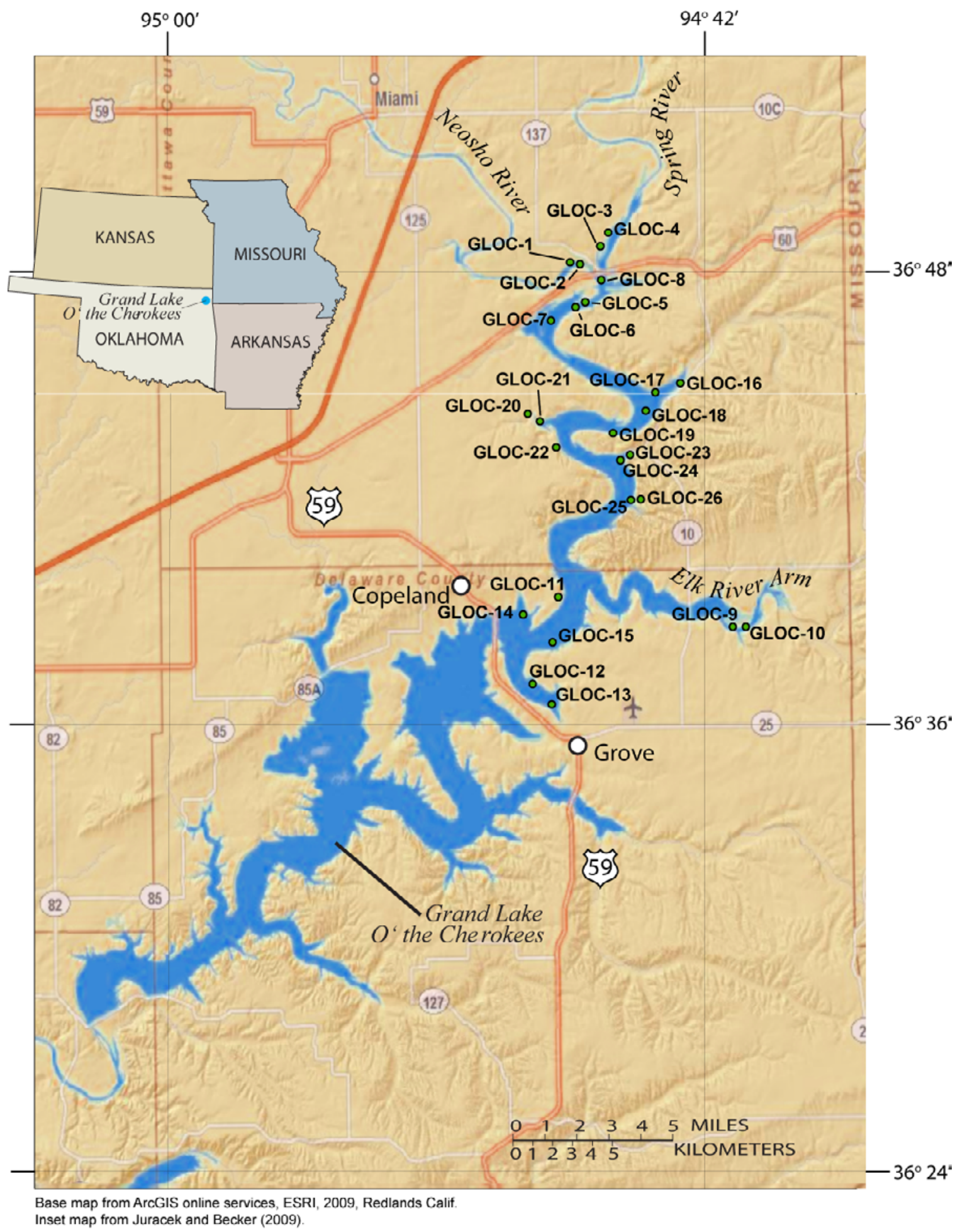

Figure 1. Location map for samples taken in the Grand Lake O' the Cherokees area in northeast Oklahoma. 
In order to record the transport and deposition from the Tri-State District of metals by the Spring and Neosho Rivers, the U.S. Geological Survey (USGS) collected 11 sediment cores and 15 bottomsediment samples from the Grand Lake O' the Cherokees in northeastern Oklahoma in September 2007. Subsamples from five selected cores and the bottom-sediment samples were analyzed for major and trace elements and forms of carbon. Presentation of the analytical results is the purpose of this report.

\section{Methods}

\section{Sediment Core Collection and Preparation}

Cores of reservoir sediment were collected at 11 sites from the Grand Lake O' the Cherokees reservoir (fig. 1). These cores were labeled GLOC-1 (Grand Lake O' the Cherokees) through GLOC-11. A 3-inch-diameter aluminum pipe (barrel) was driven down into the sediment from a pontoon raft working platform (fig. 2). A gasoline engine-powered vibrator (typically used for settling wet concrete) was attached to the barrel; this arrangement allowed the pipe to be driven to depths of 0.8-3 meters (m) (31-120 inches [in]) below the sediment-water interface (fig. 3). The depth of water where cores were taken varied from 0.6 to $3 \mathrm{~m}$ ( 2 to $10 \mathrm{feet}$ [ft]). Attempts to work in deeper water were made but were unsuccessful.

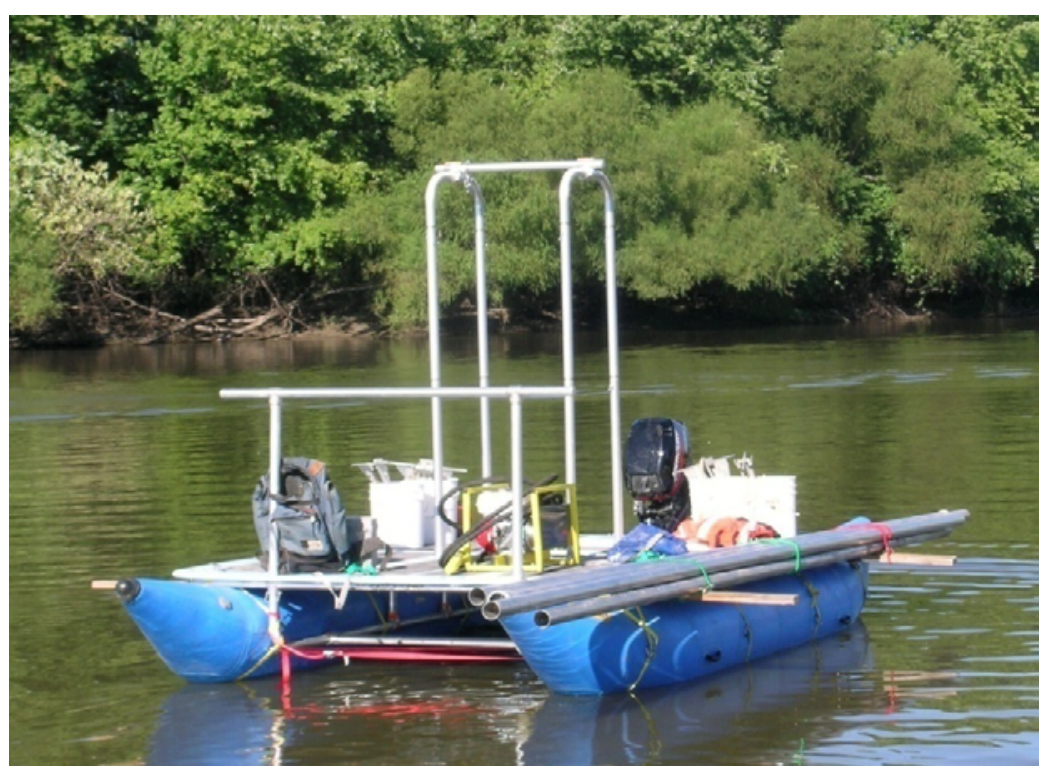

Figure 2. Pontoon boat coring platform. Aluminum tower is for attaching hand-operated winch to hoist core barrel. 


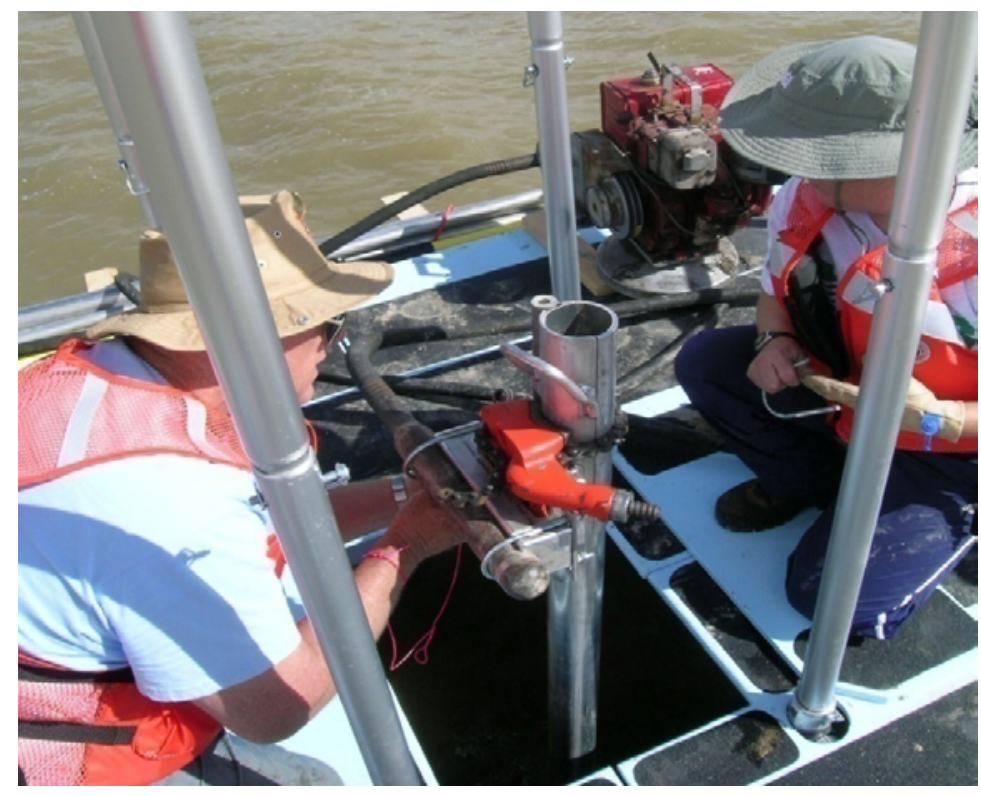

Figure 3. Close-up view of mechanical vibrator attached to core barrel. Core is standing through hole in platform deck; gasoline engine in background is used to drive the vibrator.

After the core barrel was driven to refusal, the barrel was extracted from the sediment using a hand-powered hoist attached to the tower on the working platform. When possible, the depth of penetration was recorded. The bottom of the core barrel was capped as it was lifted above the water surface. Each core barrel was transported vertically to the shore, where the position of the top of the sediment was determined, yielding the core recovery length. The remaining barrel above was cut away, and the top of the recovered core was packed with laboratory cleaning tissue (to prevent mixing of the top of core) and capped. Cores were transported to a USGS workstation warehouse in Oklahoma City, Okla. This warehouse is located at a locked, secure General Services Administration (GSA) compound. Keys to the warehouse are accessible to USGS Oklahoma Water Science Center personnel only.

The cores were stored in an upright position in a freezer from September 2007 to July 2008, at which time they were processed to yield subsamples. The cores remained sealed and frozen for the entire period of storage; taped end caps were undisturbed. In the warehouse, each core was laid horizontally in a jig, and the aluminum barrel was cut longitudinally its entire length with a hand-held circular saw. The blade depth of the saw was set to just penetrate the aluminum wall in order to avoid incorporating possible metal fragments into the sediment. The core was then rotated 180 degrees and the other side was cut in the same manner. One cut was taped with duct tape to form a hinge. The cored sample material was then cut with a plastic knife longitudinally, and one side of the barrel was rotated to expose both halves of the core. Each core was subsampled at 5-centimeter (cm) (2-in) intervals. Care was taken not to allow any contamination from the aluminum core barrel: the exterior of each subsample was scraped off and the interior sediment was carefully removed and placed in a clean glass bowl to air dry in a closed hood. A subsample of the core was taken from each interval for chemical analysis, and another subsample was taken from core GLOC-7 for ${ }^{137} \mathrm{Cs}$ (cesium-137) dating. Mark Becker of the USGS Oklahoma Water Science Center performed these tasks.

The subsamples for chemical analysis and 137Cs dating were sent by express mail to Kathleen Smith and David Fey at the USGS laboratories in Building 20 at the Denver Federal Center (DFC) in Lakewood, Colo. Building 20 is a secure building, accessible by proximity card by authorized USGS personnel only. The Denver Federal Center is a limited-access facility with guarded entrances. 
At the DFC labs, the samples were visually described, sieved to minus-80 mesh (177 micrometers $[\mu \mathrm{m}])$, and ground to minus-100 mesh $(150 \mu \mathrm{m})$. The ground samples were then split, with one set of splits kept for archival storage at the DFC and the other arranged into lots for submittal to the USGS contract laboratory SGS Minerals Services in Toronto, Canada, for analysis. Mineralogical analysis by X-ray diffraction (XRD) was performed at the Denver USGS laboratory on selected sieved, unground subsamples from cores GLOC-2, GLOC-3, and GLOC-7. During the sample description, preparation, XRD determinations, and shipping processes, the samples were kept in locked offices, locked labs, or the secure Sample Control facility contained within Building 20.

\section{Bottom Sediment Collection and Preparation}

Collecting core samples was time consuming and, in addition, not possible in deeper water, so we supplemented the sediment cores with reservoir bottom-sediment samples collected with a simple gravity corer. A single composite sample of reservoir bottom sediment was obtained at 15 sites by dropping a simple 9-cm-diameter (3.5-in-diameter) iron gravity corer from the working platform (fig. 4). The corer was unlined, and no attempt was made to preserve the stratigraphy of the samples; a composite sample was made from the sediment collected from about the top $18 \mathrm{~cm}$ (7 in) of bottom sediment. These cores were labeled GLOC-12 through GLOC-26. After collection, the bottom-sediment samples were double-bagged in large plastic storage bags and transported to the USGS Oklahoma Water Science Center warehouse described above. The bottom-sediment samples remained frozen during storage, from September 2007 to July 2008.

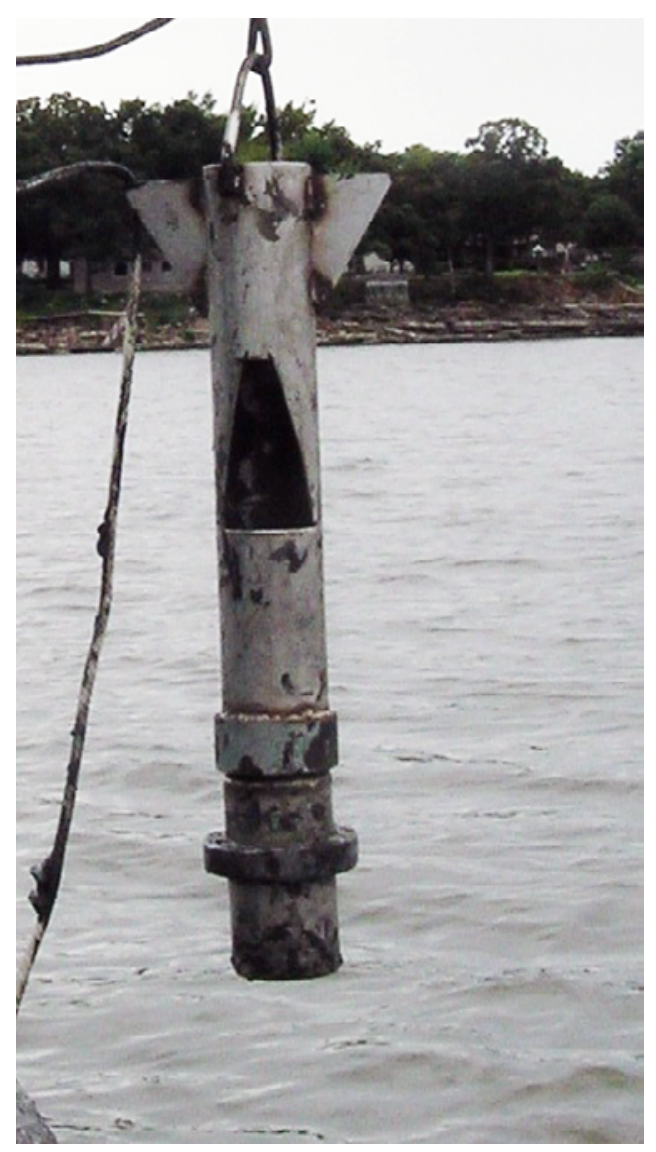

Figure 4. Simple gravity corer used to collect reservoir bottom-sediment samples. 
Samples were air-dried at the warehouse and then shipped to the Denver USGS laboratories for preparation. They were processed in the same manner as the core subsamples: sieved to minus- 80 mesh, ground to minus-100 mesh, arranged in lots, and sent to the USGS contract laboratory SGS Minerals Services in Toronto, Canada.

\section{Sample Localities and Descriptions}

Sample localities are plotted in figure 1 and listed in table 1. Table 2 contains depths of water and descriptions for the core and bottom-sediment samples.

Table 1. Field numbers, sample localities, dates, and site descriptions for core and reservoir bottom-sediment samples taken from Grand Lake O' the Cherokees, September 2007. (Click to see Excel file.)

[Sample coordinates are referenced to the World Geodetic System of 1984 and are given in decimal degree. USF, upstream from; DSF, downstream from; mi, mile; Hwy, highway]

\begin{tabular}{|c|c|c|c|c|}
\hline $\begin{array}{c}\text { Core } \\
\text { number }\end{array}$ & $\begin{array}{c}\text { North } \\
\text { latitude }\end{array}$ & $\begin{array}{c}\text { West } \\
\text { longitude }\end{array}$ & Date & Site description \\
\hline GLOC-1 & 36.80410 & 94.76656 & $9 / 12 / 2007$ & Neosho River about 0.7 mi USF Hwy 60 bridge \\
\hline GLOC-2 & 36.80331 & 94.76100 & $9 / 12 / 2007$ & Neosho River about $0.4 \mathrm{mi}$ USF Hwy 60 bridge \\
\hline GLOC-3 & 36.81125 & 94.74951 & 9/13/2007 & Spring River about 0.8 mi USF Hwy 60 bridge \\
\hline GLOC-4 & 36.81717 & 94.74482 & $9 / 13 / 2007$ & Spring River about $1.3 \mathrm{mi}$ USF Hwy 60 bridge \\
\hline GLOC-5 & 36.78646 & 94.75837 & $9 / 13 / 2007$ & reservoir about $0.5 \mathrm{mi}$ DSF railroad bridge \\
\hline GLOC-6 & 36.78439 & 94.76396 & $9 / 13 / 2007$ & reservoir about $0.3 \mathrm{mi}$ DSF from GLOC-5 \\
\hline GLOC-7 & 36.77851 & 94.77760 & $9 / 13 / 2007$ & reservoir about $0.9 \mathrm{mi}$ DSF from GLOC- 6 \\
\hline GLOC-8 & 36.79668 & 94.75351 & $9 / 13 / 2007$ & reservoir at confluence of Spring and Neosho Rivers \\
\hline GLOC-9 & 36.64159 & 94.68297 & $9 / 14 / 2007$ & Elk River about 1.7 mi USF from Cowskin Bridge \\
\hline GLOC-10 & 36.64157 & 94.67565 & $9 / 14 / 2007$ & Elk River about $2.1 \mathrm{mi}$ USF from Cowskin Bridge \\
\hline GLOC-11 & 36.65591 & 94.77567 & $9 / 14 / 2007$ & reservoir right bank, across from Elk River arm \\
\hline GLOC-12 & 36.61737 & 94.79456 & $9 / 15 / 2007$ & Wolf Creek Cove \\
\hline GLOC-13 & 36.60817 & 94.78305 & $9 / 15 / 2007$ & upper Wolf Creek Cove \\
\hline GLOC-14 & 36.64812 & 94.79848 & $9 / 15 / 2007$ & reservoir near Hickory Creek Island \\
\hline GLOC-15 & 36.63576 & 94.77902 & $9 / 15 / 2007$ & reservoir main channel near Walnut Cove \\
\hline GLOC-16 & 36.74973 & 94.71201 & $9 / 15 / 2007$ & upper Sycamore Cove \\
\hline GLOC-17 & 36.74627 & 94.72341 & $9 / 15 / 2007$ & lower Sycamore Cove \\
\hline GLOC-18 & 36.74020 & 94.72669 & $9 / 15 / 2007$ & mouth of Sycamore Cove \\
\hline GLOC-19 & 36.72820 & 94.74387 & $9 / 15 / 2007$ & reservoir between Sycamore and Bee Creek Coves \\
\hline GLOC-20 & 36.73712 & 94.79139 & $9 / 15 / 2007$ & upper Bee Creek Cove \\
\hline GLOC-21 & 36.73369 & 94.78447 & $9 / 15 / 2007$ & mouth of Bee Creek Cove \\
\hline GLOC-22 & 36.72219 & 94.77583 & $9 / 15 / 2007$ & reservoir about 0.9 mi below Bee Creek Cove \\
\hline GLOC-23 & 36.71917 & 94.73907 & $9 / 15 / 2007$ & upper Council Cove \\
\hline GLOC-24 & 36.71709 & 94.74388 & $9 / 15 / 2007$ & mouth of Council Cove \\
\hline GLOC-25 & 36.69832 & 94.73851 & $9 / 15 / 2007$ & main channel, near North Broad Hollow \\
\hline GLOC-26 & 36.69864 & 94.73283 & 9/15/2007 & upper North Broad Hollow \\
\hline
\end{tabular}


Table 2. Field numbers, water depths, and visual sample descriptions for core and reservoir bottom-sediment samples taken from Grand Lake O' the Cherokees, September 2007. (Click to see Excel file.)

$[\mathrm{m}$, meter; in, inch]

\begin{tabular}{lrl}
\hline Core number & $\begin{array}{c}\text { Depth of } \\
\text { water }(\mathbf{m})\end{array}$ & \multicolumn{1}{c}{ Sample description } \\
\hline GLOC-1 & 3 & core: silt and clay, sparse fine sand \\
GLOC-2 & 0.6 & core: silt and clay, sparse fine sand \\
GLOC-3 & 0.9 & core: fine sand and silt, little clay \\
GLOC-4 & 0.6 & core: brown/gray clay, some silt at bottom; fine brown sand \\
GLOC-5 & 1.2 & core: 63 in penetration; 38 in recovery \\
GLOC-6 & 6.7 & no sample taken; encountered bedrock at bottom of reservoir \\
GLOC-7 & 1.2 & core: gray clayey silt; 72 in penetration, 54 in recovery \\
GLOC-8 & 1.2 & core: penetration/recovery not recorded \\
GLOC-9 & 1.2 & core: 94 in penetration, 90 in recovery \\
GLOC-10 & 1.2 & core: 120 in penetration, 90 in recovery; brown clay \\
GLOC-11 & 1.5 & core: 32 in penetration, recovery not recorded \\
GLOC-12 & 5.2 & reservoir sediment: dark gray very fine sand \\
GLOC-13 & 2.4 & reservoir sediment: dark gray very fine sand \\
GLOC-14 & 6.7 & reservoir sediment: dark gray very fine sand \\
GLOC-15 & 13 & reservoir sediment: dark gray very fine sand \\
GLOC-16 & 2.1 & reservoir sediment: dark gray very fine sand \\
GLOC-17 & 2.1 & reservoir sediment: dark gray very fine sand with quartz grains \\
GLOC-18 & 1.5 & reservoir sediment: gray very fine sand \\
GLOC-19 & 6.7 & reservoir sediment: gray very fine sand \\
GLOC-20 & 0.9 & reservoir sediment: gray very fine sand \\
GLOC-21 & 4.3 & reservoir sediment: gray very fine sand \\
GLOC-22 & 7.3 & reservoir sediment: gray very fine sand \\
GLOC-23 & 2.4 & reservoir sediment: gray-brown very fine sand \\
GLOC-24 & 4.3 & reservoir sediment: gray-brown very fine sand \\
GLOC-25 & 7.9 & reservoir sediment: gray-brown very fine sand \\
GLOC-26 & 4.9 & reservoir sediment: gray-brown very fine sand \\
\hline & &
\end{tabular}

\section{X-Ray Diffraction Analyses}

Forty-one selected core subsamples were analyzed for mineralogical content by X-ray diffraction (XRD) using a Shimadzu XRD-6000 X-Ray diffractometer equipped with a standard copper $(\mathrm{Cu}) \mathrm{K}$-alpha radiation tube, monochronometer, and automatic 5-sample changer. All samples were powdered using an agate mortar and pestle. Each sample powder was mixed with a few drops of acetone to form a slurry, which was transferred by pipette to a zero-background quartz slide. These slurry mounts were inserted into the sequential auto sample changer.

Raw XRD data acquired from the instrument were analyzed using Jade Search/Match software, version 7.5. The data were converted to diffractograms, which were background-reduced and smoothed. Mineral phase identities, selected from the International Centre for Diffraction Data (ICDD) database, were assigned to all visible peaks. Phase quantification was based on a visual comparison of peak intensitities and assigned $M$ for major constituent, $m$ for minor constituent, and $t$ for trace values. Inconclusive phase identifications were assigned a $p$ for possible. Table 3 presents the XRD data for a subset of samples from cores GLOC-2, GLOC-3, and GLOC-7. 
Table 3. Field numbers and mineralogy by X-ray diffraction for subsamples from cores GLOC-2, GLOC-3, and GLOC-7 from Grand Lake O' the Cherokees (GLOC). No sulfide minerals were detected by this method. (Click to see Excel file.)

[cm, centimeter; $\mathrm{M}$, major constituent; $\mathrm{m}$, minor constituent; $\mathrm{p}$, possible, followed by either $\mathrm{m}$ or $\mathrm{t}$; t,trace. Qtz, quartz; Ms,muscovite; Ill,Illite; Phg,phengite; Ab,albite; Mc,microcline; Or,orthoclase; Sa,sanidine; Kln,Kaolinite; Chl,chlorite; Sme, smectite]

\begin{tabular}{|c|c|c|c|c|c|c|c|c|c|}
\hline Core number & $\begin{array}{l}\text { Depth below } \\
\text { water/sediment } \\
\text { interface }(\mathrm{cm})\end{array}$ & Qtz & Ms/III & Ms/Phg & $A b$ & Mc & Or/Sa & $\mathrm{Kln} / \mathrm{Chl}$ & Sme \\
\hline GLOC-2 1-3 & 5 & $\mathrm{M}$ & $\mathrm{m}$ & & $\mathrm{m}$ & & $\mathrm{m}$ & & \\
\hline GLOC-2 5-7 & 15 & M & $\mathrm{m}$ & & $\mathrm{m}$ & $\mathrm{m}$ & & $\mathrm{p}, \mathrm{t}$ & $\mathrm{p}, \mathrm{t}$ \\
\hline GLOC-2 9-11 & 25 & M & $\mathrm{m}$ & & $\mathrm{m}$ & $\mathrm{m}$ & & $\mathrm{p}, \mathrm{t}$ & \\
\hline GLOC-2 13-15 & 35 & M & $\mathrm{m}$ & & $\mathrm{m}$ & $\mathrm{m}$ & & $\mathrm{p}, \mathrm{t}$ & $\mathrm{p}, \mathrm{t}$ \\
\hline GLOC-2 17-19 & 45 & M & $\mathrm{m}$ & & $\mathrm{m}$ & & & $\mathrm{p}, \mathrm{t}$ & $\mathrm{p}, \mathrm{t}$ \\
\hline GLOC-2 21-23 & 55 & M & $\mathrm{m}$ & & $\mathrm{m}$ & $\mathrm{m}$ & $\mathrm{m}$ & & $\mathrm{t}$ \\
\hline GLOC-2 25-27 & 65 & $\mathrm{M}$ & $\mathrm{m}$ & & $\mathrm{m}$ & & $\mathrm{m}$ & & $\mathrm{p}, \mathrm{t}$ \\
\hline GLOC-2 29-31 & 75 & M & $\mathrm{m}$ & & $\mathrm{m}$ & $\mathrm{m}$ & & $\mathrm{p}, \mathrm{t}$ & \\
\hline GLOC-2 33-35 & 85 & M & $\mathrm{m}$ & & $\mathrm{m}$ & & $\mathrm{m}$ & & $\mathrm{m}$ \\
\hline GLOC-2 37-39 & 95 & M & $\mathrm{m}$ & & $\mathrm{m}$ & $\mathrm{m}$ & & & \\
\hline GLOC-2 41-43 & 105 & M & $\mathrm{m}$ & & $\mathrm{m}$ & $\mathrm{m}$ & & & \\
\hline GLOC-2 45-47 & 115 & M & $\mathrm{m}$ & & $\mathrm{m}$ & $\mathrm{m}$ & $\mathrm{m}$ & $\mathrm{p}, \mathrm{t}$ & $\mathrm{m}$ \\
\hline GLOC-2 55-57 & 140 & M & $\mathrm{m}$ & & $\mathrm{m}$ & $\mathrm{m}$ & & & $\mathrm{p}, \mathrm{t}$ \\
\hline GLOC-2 65-67 & 165 & M & $\mathrm{m}$ & & $\mathrm{m}$ & $\mathrm{m}$ & & & $\mathrm{p}, \mathrm{t}$ \\
\hline GLOC-2 75-77 & 190 & M & $\mathrm{m}$ & & $\mathrm{m}$ & & $\mathrm{m}$ & $\mathrm{t}$ & $\mathrm{t}$ \\
\hline GLOC-2 85-87 & 215 & M & $\mathrm{m}$ & & & $\mathrm{m}$ & $\mathrm{m}$ & & \\
\hline GLOC-2 95-97 & 240 & M & M & & & $\mathrm{m}$ & $\mathrm{m}$ & & \\
\hline GLOC-2 105-107 & 265 & M & M & & & $\mathrm{m}$ & $\mathrm{m}$ & & \\
\hline GLOC-2 115-117 & 290 & M & $\mathrm{m}$ & & $\mathrm{m}$ & & & & \\
\hline GLOC-2 121-123 & 300 & M & $\mathrm{m}$ & & $\mathrm{m}$ & & $\mathrm{m}$ & $\mathrm{p}, \mathrm{t}$ & $\mathrm{p}, \mathrm{t}$ \\
\hline GLOC-3 $0-2$ & 2.5 & M & $\mathrm{m}$ & & $\mathrm{p}, \mathrm{t}$ & & & & \\
\hline GLOC-3 4-6 & 13 & M & & $\mathrm{m}$ & $\mathrm{m}$ & $\mathrm{m}$ & & & \\
\hline GLOC-3 8-10 & 23 & M & $\mathrm{t}$ & & $\mathrm{t}$ & $\mathrm{t}$ & & & \\
\hline GLOC-3 $12-14$ & 33 & M & $\mathrm{t}$ & & $\mathrm{m}$ & $\mathrm{m}$ & $\mathrm{m}$ & $\mathrm{p}, \mathrm{t}$ & \\
\hline GLOC-3 16-18 & 38 & M & $\mathrm{t}$ & & $\mathrm{m}$ & & $\mathrm{m}$ & & \\
\hline GLOC-3 20-22 & 53 & M & $\mathrm{m}$ & & $\mathrm{m}$ & $\mathrm{m}$ & & & \\
\hline GLOC-3 24-26 & 63 & M & & $\mathrm{t}$ & $\mathrm{m}$ & $\mathrm{m}$ & & & \\
\hline GLOC-3 28-30 & 73 & M & $\mathrm{m}$ & & & $\mathrm{m}$ & $\mathrm{m}$ & & $\mathrm{p}, \mathrm{t}$ \\
\hline GLOC-3 32-34 & 83 & M & $\mathrm{t}$ & & $\mathrm{m}$ & $\mathrm{p}, \mathrm{m}$ & & $\mathrm{p}, \mathrm{t}$ & \\
\hline GLOC-3 36-38 & 93 & M & $\mathrm{m}$ & & $\mathrm{m}$ & $\mathrm{m}$ & & & $\mathrm{m}$ \\
\hline GLOC-3 40-42 & 103 & M & $\mathrm{t}$ & & & & $\mathrm{m}$ & & $\mathrm{p}, \mathrm{t}$ \\
\hline GLOC-3 44-46 & 113 & M & $\mathrm{m}$ & & $\mathrm{m}$ & $\mathrm{m}$ & & & \\
\hline GLOC-3 48-50 & 123 & M & $\mathrm{m}$ & & $\mathrm{m}$ & & $\mathrm{m}$ & & \\
\hline GLOC-3 52-54 & 133 & M & $\mathrm{m}$ & & $\mathrm{m}$ & $\mathrm{m}$ & & & $\mathrm{p}, \mathrm{t}$ \\
\hline GLOC-3 56-58 & 143 & M & $t$ & & $\mathrm{~m}$ & $\mathrm{~m}$ & $\mathrm{~m}$ & & $\mathrm{p}, \mathrm{t}$ \\
\hline GLOC-3 60-62 & 153 & M & & $\mathrm{t}$ & $\mathrm{t}$ & $\mathrm{t}$ & & & $\mathrm{p}, \mathrm{t}$ \\
\hline GLOC-3 64-66 & 163 & M & $\mathrm{t}$ & & & & $\mathrm{m}$ & & \\
\hline GLOC-3 68-70 & 173 & M & $\mathrm{t}$ & & $\mathrm{t}$ & $\mathrm{t}$ & & & \\
\hline GLOC-3 72-74 & 178 & M & $\mathrm{t}$ & & $\mathrm{m}$ & $\mathrm{m}$ & $\mathrm{m}$ & & \\
\hline GLOC-7 6-8 & 18 & M & $\mathrm{m}$ & & M & & M & $\mathrm{p}, \mathrm{t}$ & $\mathrm{p}, \mathrm{t}$ \\
\hline GLOC-7 38-40 & 98 & M & & $\mathrm{m}$ & $\mathrm{m}$ & & $\mathrm{m}$ & & \\
\hline
\end{tabular}




\section{Multi-Element Analysis}

Processed core subsamples and reservoir bottom sediment samples were weighed at SGS Mineral Services laboratories into 0.2-gram (g) aliquots and digested in a mixed four-acid medium of hydrochloric, nitric, perchloric, and hydrofluoric acids $\left(\mathrm{HCl}, \mathrm{HNO}_{3}, \mathrm{HClO}_{4}\right.$, and $\mathrm{HF}$, respectively). The resulting solutions were analyzed for 26 elements by both inductively coupled plasma-atomic emission spectroscopy (ICP-AES) (Briggs, 2002) and inductively coupled plasma-mass spectrometry (ICP-MS) (Briggs and Meier, 2002). The major elements are reported from the ICP-AES instrument, whereas the trace elements are reported from either the ICP-AES or ICP-MS instrument. Instrument sensitivities, linear range, and freedom from spectral or mass interferences determine which instrument is used to report which elements. Table 1-1 in the appendix lists the elements analyzed, their lower reporting limits, and, for the 26-element package, which instrument was used for each element (ICP-AES or ICPMS). The digestion procedure dissolves most minerals, including silicates, oxides, and sulfides; resistant or refractory minerals such as zircon, chromite, some rare-earth minerals, and some tin oxides are only partially dissolved. Previous investigations using a variety of geologic materials confirm the completeness of the digestion (Church and others, 1987; Wilson and others, 1994). For the purposes of analyzing for Mississippi Valley-type mineral deposit-related elements, the digestion is well suited.

\section{Forms of Carbon Analyses}

The core subsamples and bottom-sediment samples were analyzed for total carbon and carbonate carbon. The organic carbon content is obtained by the difference between those constituents. The total carbon was determined by combustion (Brown and Curry, 2002), where a 0.2-g sample is heated to $1,350^{\circ} \mathrm{C}$ to convert all forms of carbon to carbon dioxide, which is then measured using an infrared detector. The carbonate carbon was determined by a coulometric titration (Brown and others, 2002), where the sample is treated with hot 2 Normal perchloric acid and the evolved carbon dioxide is passed through a solution of monoethanolamine, into which it is quantitatively absorbed. This solution is then coulometrically titrated. The lower reporting limit for organic carbon is 0.05 percent. 


\section{Results}

The analytical results for five of the sediment cores and the 15 bottom-sediment samples are in tables 1-2 through 1-7 in appendix 1. In this section are brief discussions with descriptive statistics for each table. To aid in these discussions, table 4 provides estimated crustal abundance values (Fortescue, 1992) for all constituents analyzed.

Table 4. Crustal abundance values for elements analyzed in this report. (Click to see Excel file.)

[Values taken from Fortescue (1992). ppm, parts per million]

\begin{tabular}{|c|c|c|}
\hline Element & $\begin{array}{c}\text { Crustal } \\
\text { abundance }\end{array}$ & Unit \\
\hline $\mathrm{Al}$ & 8.36 & percent \\
\hline $\mathrm{Ca}$ & 4.66 & percent \\
\hline $\mathrm{Fe}$ & 6.22 & percent \\
\hline K & 1.84 & percent \\
\hline $\mathrm{Mg}$ & 2.76 & percent \\
\hline $\mathrm{Na}$ & 2.27 & percent \\
\hline $\mathrm{P}$ & 0.112 & percent \\
\hline $\mathrm{Ti}$ & 0.632 & percent \\
\hline S & 340 & ppm \\
\hline As & 1.8 & ppm \\
\hline $\mathrm{Ba}$ & 390 & ppm \\
\hline $\mathrm{Bi}^{*}$ & 0.0082 & ppm \\
\hline $\mathrm{Cd}$ & 0.16 & ppm \\
\hline Co & 29 & ppm \\
\hline $\mathrm{Cr}$ & 122 & ppm \\
\hline $\mathrm{Cu}$ & 68 & ppm \\
\hline $\mathrm{Ga}$ & 19 & ppm \\
\hline In & 0.24 & ppm \\
\hline $\mathrm{Li}$ & 18 & ppm \\
\hline $\mathrm{Mn}$ & 1,060 & ppm \\
\hline $\mathrm{Ni}$ & 99 & ppm \\
\hline $\mathrm{Pb}$ & 13 & ppm \\
\hline $\mathrm{Rb}$ & 78 & ppm \\
\hline $\mathrm{Sr}$ & 384 & ppm \\
\hline $\mathrm{V}$ & 136 & ppm \\
\hline $\mathrm{Zn}$ & 76 & ppm \\
\hline
\end{tabular}

*Value for Bi commented by Fortescue to be too small.

\section{Bottom-Sediment Samples (Table 1-2)}

The 15 bottom-sediment samples were taken from throughout the Grand Lake O' the Cherokees reservoir above Highway 59 bridge between Grove and Copeland and from several arms of the reservoir (samples GLOC-12 through GLOC-26 on fig. 1). These samples were collected by gravity corer and represent about the top $18 \mathrm{~cm}$ ( 7 in) of sediment. The top three intervals together of each sediment core also represent about $18 \mathrm{~cm}$. In table 1-2, a 'composite' analysis has been made of the analyses of the first three intervals from cores GLOC-2, GLOC-3, GLOC-7, GLOC-8, and GLOC-9. The inclusion of these composite analyses increases the number of points in the reservoir with metals-content analyses of the bottom sediments at the sediment-water interface. 
The XRD determinations for sediment mineralogy (table 3) show that the major constituent for all samples from the bottom surface and the cores is quartz. Predominance of quartz in the samples is also supported by the major-element analyses in table 1-2. By converting the major-element analyses to their respective oxide forms, summing them, and subtracting that sum from 100 percent, a rough estimate can be made of the $\mathrm{SiO}_{2}$ content of the sediments. For the bottom-sediment samples in table $1-2$, the average of this estimated $\mathrm{SiO}_{2}$ content is 80 percent quartz equivalent. Some of the silica is contained in clays.

Other elements of table 1-2 are depleted compared to crustal abundance, again reflecting that the stream/river/lake environment has favored the retention of $\mathrm{SiO}_{2}$. Evaluating the calcium analyses shows that, on average, the ratio of calcium to crustal abundance is only 18 percent. This deficiency of calcium reflects the fact that although much of the upstream rock is carbonate, it dissolves and releases calcium into solution. Other major elements with low ratios to crustal abundance are magnesium $(\mathrm{Mg})$ and sodium (Na; each 17 percent), iron (Fe; 43 percent), and titanium (Ti; 38 percent). The magnesium has probably been mobilized like the calcium, whereas the low numbers for $\mathrm{Na}, \mathrm{Fe}$, and Ti probably reflect low concentrations in the original carbonate rocks.

Three major elements show higher ratios to crustal abundance. Aluminum (Al) has a value of 70 percent, and potassium $(\mathrm{K})$ has a value of 77 percent, reflecting the clay content in the sediment. Sulfur (S) had a ratio to crustal abundance of 310 percent; although the highest concentration of sulfur was only 0.33 percent, the high ratio may be due to runoff from the metallic sulfide mining districts upstream of the reservoir.

The trace elements had ratios to crustal abundance mostly near or below 1.0, with exceptions being $\mathrm{Zn}$ (7.2), $\mathrm{Cd}$ (21), As (arsenic; 4.5), and $\mathrm{Pb}$ (3.3). The crustal abundance for zinc is 76 parts per million (ppm); the concentrations in the bottom-sediment samples ranged from 56 ppm (background, GLOC-9, Elk River Arm, table 1-7) to 1,523 ppm (20 times crustal abundance; GLOC-8, confluence of Neosho and Spring Rivers, table 1-6). Zinc is the most likely indicator of input from the mining districts, detected in sediment samples collected upstream of the reservoir in both the Spring and Neosho Rivers, and plays a major role in the discussions of the sediment cores. The zinc concentration at the top of core GLOC-2 (the surface sediment) collected in the Neosho River from the reservoir was only $122 \mathrm{ppm}$, less than 2 times crustal abundance. This enrichment is relatively slight, given that this location is downstream from the Picher district and Tar Creek (Andrews and others, 2009). The zinc concentration at the top of core GLOC-3 was $1,370 \mathrm{ppm}$. This relative enrichment of zinc indicates that sediment from the Spring River predominated the deposition at the surface at site GLOC-8, just below the confluence of the Spring and Neosho Rivers. Andrews and others (2009) noted that dissolved zinc concentrations in the Spring River might be higher than those in the Neosho River because a larger proportion of the Spring River basin had been mined (1.9 percent) than of the Neosho River basin (0.34 percent).

Overall, the distribution of zinc in the reservoir bottom sediments shows a general elevation of zinc in those drainages affected by historical mining operations. Of the 20 bottom-sediment samples represented in table 1-2 (15 gravity corer samples and 5 core upper interval composite analyses), 13 averaged $490 \mathrm{ppm}$, with only a 15 percent standard deviation. Thus, the zinc is fairly evenly distributed at the surface of the sediment. Outlier numbers can be explained by contribution from local terrestrial sediment input. For example, site GLOC-20 is located at the head of Bee Cove, and the sample was collected within meters of where Bee Creek enters the reservoir. The zinc concentration of that sample was $242 \mathrm{ppm}$. The local terrestrial sedimentation would serve to dilute, for a short distance, the effect of higher zinc concentrations in the sediment of the reservoir. Sample GLOC-21 supports this hypothesis. Located near the mouth of Bee Cove, just $0.8 \mathrm{~km}(0.5 \mathrm{mi})$ away, but exposed to the reservoir, the zinc 
concentration of this sample was 528 ppm. Likewise, GLOC-23 is located at the upper end of Council Cove and contained only $134 \mathrm{ppm}$ zinc. Local sedimentation also may be diluting the cove sediment at that location. Just $0.5 \mathrm{~km}$ away $(0.3 \mathrm{mi})$ at the mouth of Council Cove, sample GLOC-24 contained 478 ppm zinc. As mentioned above, a sample was taken from the upper part of the Elk River arm of the reservoir (core GLOC-9). The Elk River drains a watershed with no known mining activity, and so sediment collected from that arm serves as a background comparison. The average zinc concentration from the top three intervals of GLOC-9 was only $56 \mathrm{ppm}$.

Cadmium, which is chemically similar to zinc and substitutes in the sphalerite lattice, had a high average ratio to crustal abundance of 21 in the bottom-sediment samples. The highest cadmium concentration (19 ppm) occurred in the same sample as the highest zinc concentration (GLOC-8, confluence of Spring and Neosho Rivers).

The average arsenic ratio to crustal abundance was 4.5, although absolute concentrations were generally less than $10 \mathrm{ppm}$.

The lead concentrations in the bottom-sediment samples are moderate, averaging only $43 \mathrm{ppm}$. Although these samples were collected relatively close to the former mining districts to the north, the lead concentrations are only three times crustual abundance $(13 \mathrm{ppm})$ in the sediment. One of the two primary commodities mined was lead. To that end, producers tried to retain as much lead as possible in the milled and refined product and not release notable quantities of lead in the tailings. Second, the specific gravity of galena, the primary lead-bearing mineral, is high at about 7.5, so any galena released in the mining or milling stages likely would remain close to the initital source in the stream system as detrital grains. In addition, galena is not very soluble under the near-neutral conditions common in these stream waters (Weast, 1978). Conversely, zinc is highly mobile in the aqueous phase once it has been dissolved from sphalerite (Stumm and Morgan, 1981). Thus, zinc has the ability to move relatively far and quickly and can settle into bed sediment sorbed to colloidal iron phases or coprecipitated with other phases.

The total carbon content in the bottom-sediment samples ranged from 0.86 percent to 4.6 percent. The carbonate carbon content was low, averaging 0.06 percent, and ranging from 0.01 percent to 0.23 percent, with a median concentration of 0.03 percent. Thus, carbon was mostly in the organic form within the sediments.

\section{Core GLOC-9 Elk River Arm of Grand Lake O' the Cherokees (Table 1-3)}

The core site in the Elk River arm of Grand Lake O' the Cherokees was chosen because the Elk River drains a watershed that does not contain Tri-State mining districts, and the site was expected to define local background concentrations for mining-related elements. This core seemed to have minimal, if any, influence from mining-related elements.

The estimated $\mathrm{SiO}_{2}$ content in core GLOC-9 averaged 88 percent. All of the other major element concentrations were less than crustal abundance. Calcium and magnesium concentration ratios were at 8 and 9 percent of crustal abundance, respectively. The median iron concentration ratio was 27 percent, whereas the ratio for sodium was 10 percent of crustal abundance. Aluminum and potassium median concentrations were greater, each at about 50 percent of crustal abundance, probably reflecting the clay content of the sediment.

Trace-element concentrations in core GLOC-9 were uniformly small, although arsenic (median 4 ppm) and cadmium (median $0.3 \mathrm{ppm}$ ) concentrations were two times crustal abundance. Lead concentrations averaged slightly greater than crustal abundance at $16 \mathrm{ppm}$. The copper concentrations from the background core averaged $12 \mathrm{ppm}$, less than the crustal abundance concentration of $68 \mathrm{ppm}$. 
There were no clear trends with depth for $\mathrm{As}, \mathrm{Cd}$, or $\mathrm{Pb}$ in this core. Figure 1-1 shows the concentration versus depth profile for $\mathrm{Cd}, \mathrm{Pb}$, and $\mathrm{Zn}$ for core GLOC-9.

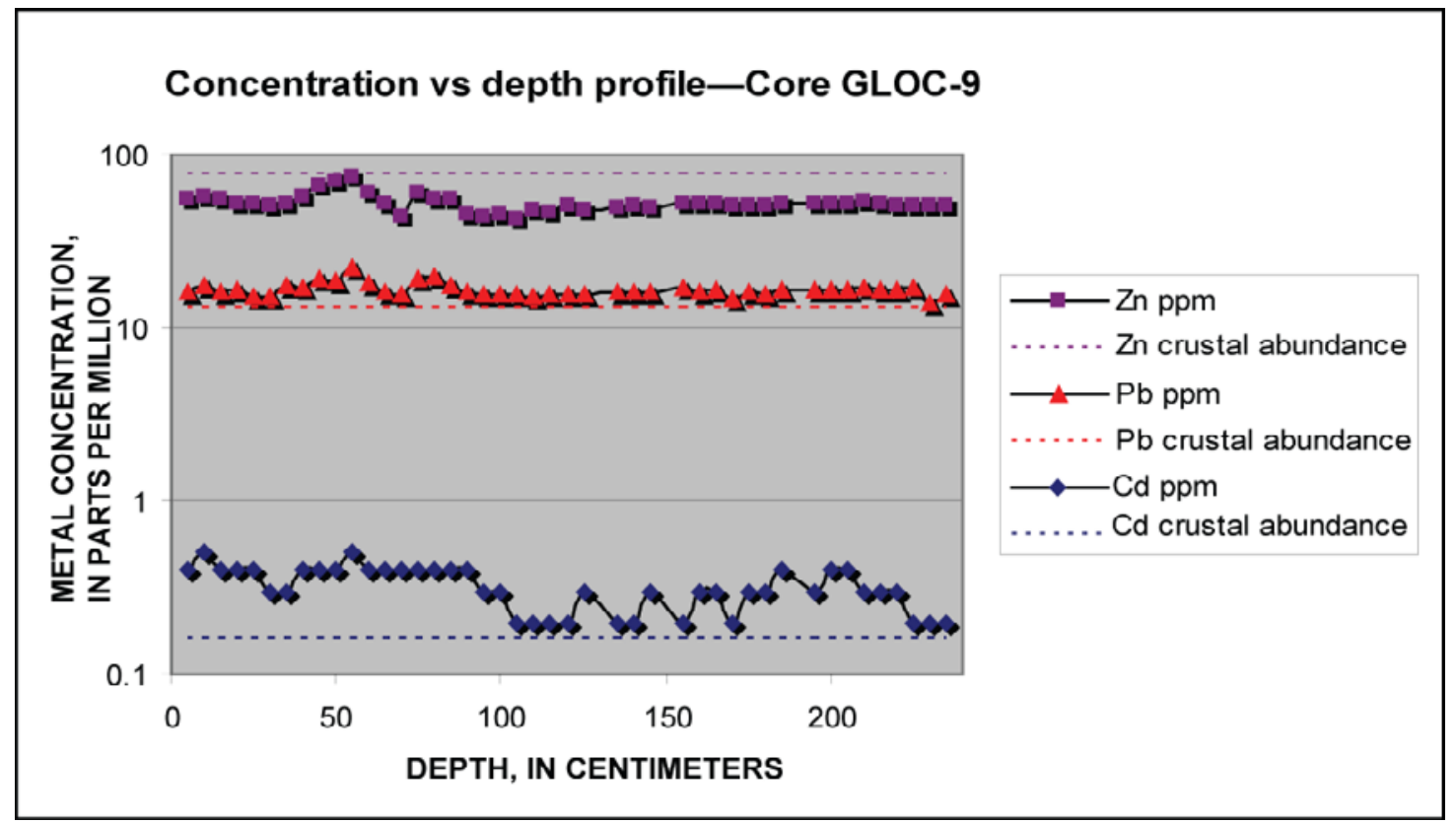

Figure 1-1. Concentration versus depth profile for cadmium $(\mathrm{Cd})$, lead $(\mathrm{Pb})$, and zinc $(\mathrm{Zn})$ for background core GLOC-9.

Zinc concentrations in this core averaged $52 \mathrm{ppm}$, below crustal abundance, but there was some variability in the upper part of the core. The top three intervals of this core had an average zinc concentration of $52 \mathrm{ppm}$. At a depth of $55 \mathrm{~cm}$ (22 in), there was a maximum concentration of $74 \mathrm{ppm}$, which was followed by an irregular decrease of concentrations to $45 \mathrm{ppm}$ at 90 -cm (35-in) depth. From there to the bottom of the core (235 $\mathrm{cm}$ [93 in]), the zinc concentration averaged $50 \mathrm{ppm}$. 


\section{Core GLOC-2 Neosho River above Reservoir (Table 1-4)}

Core GLOC-2 was collected on the Neosho River about $1 \mathrm{~km}(0.6 \mathrm{mi})$ upstream from its confluence with the Spring River. Although the surface samples from this core, discussed previously, contained near-background concentrations of most elements, subsamples deeper in the core contained higher concentrations of As, Cd, and Zn. Figure 1-2 shows the concentration versus depth profile for $\mathrm{Cd}, \mathrm{Pb}$, and $\mathrm{Zn}$ for core GLOC-2.

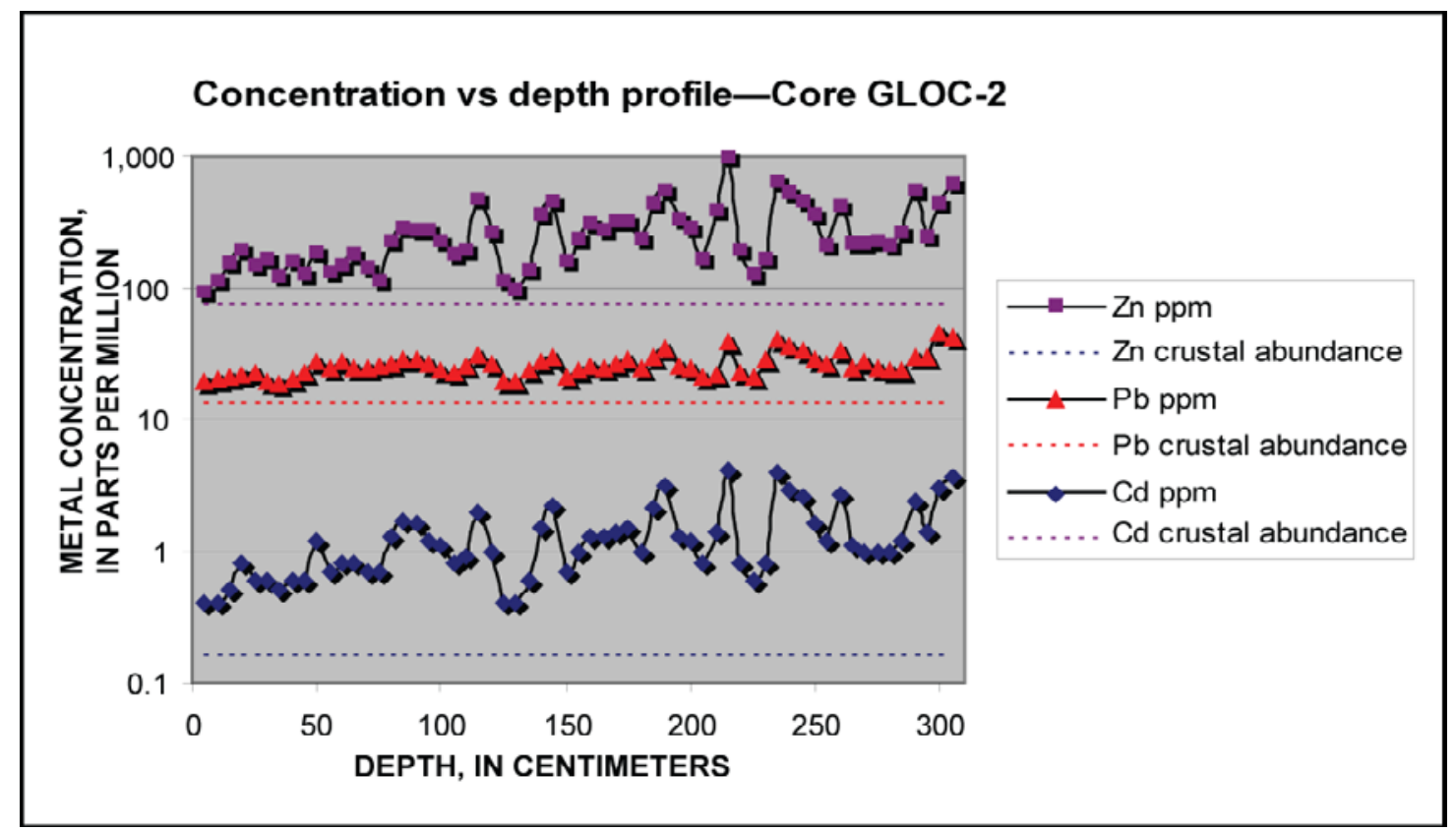

Figure 1-2. Concentration versus depth profile for cadmium ( $\mathrm{Cd})$, lead $(\mathrm{Pb})$, and zinc $(\mathrm{Zn})$ for core GLOC-2.

Arsenic concentrations ranged from 4 to $15 \mathrm{ppm}$, with the median concentration ( $7 \mathrm{ppm}$ ) having a ratio to crustal abundance of 3.9. The cadmium concentrations ranged from 0.4 to $4.1 \mathrm{ppm}$, with the median concentration $(1.1 \mathrm{ppm})$ resulting in a ratio to crustal abundance of 7.3 and a ratio to the local background determined from core GLOC-9 of 3.6. Lead concentrations were only slightly greater than the background concentration, with the high concentration being $45 \mathrm{ppm}$ at a depth of $300 \mathrm{~cm}$ (118 in). The ratio of the median lead concentration $(25 \mathrm{ppm})$ to the background concentration was 1.9 , about half that for the surface sediment samples.

The uppermost interval from core GLOC-2 had a zinc concentration of $95 \mathrm{ppm}$. Down to a depth of $65 \mathrm{~cm}$ (26 in), the zinc concentration averaged $160 \mathrm{ppm}$. With increasing depth, zinc concentrations increased irregularly, reaching a peak of $1,000 \mathrm{ppm}$ at a depth of $215 \mathrm{~cm}$ (85 in). The median zinc concentration for the whole core was $230 \mathrm{ppm}$ - three times crustal abundance and 4.4 times the local background as determined from core GLOC-9.

The major element concentrations and ratios to crustal abundance in this core were similar to those of the surface sediment samples discussed previously. 


\section{Core GLOC-3 Spring River above Reservoir (Table 1-5)}

Core GLOC-3 was collected on the Spring River about $1.6 \mathrm{~km}(1 \mathrm{mi})$ upstream from the confluence with the Neosho River. This core had numerous subsamples with concentrations of $\mathrm{Cd}, \mathrm{Pb}$, and $\mathrm{Zn}$ far greater than crustal abundance levels and had definitive trends with depth. The major element concentration ratios to crustal abundance of this core were similar to those of the surface sediments.

Figure 1-3 shows the concentration versus depth profile for $\mathrm{Cd}, \mathrm{Pb}$, and $\mathrm{Zn}$ for core GLOC-3. Cadmium concentrations in the top $50 \mathrm{~cm}$ (20 in) were about $10 \mathrm{ppm}$ and then increased to over $30 \mathrm{ppm}$ between 80- and 90-cm depth (31-35 in); this value is about 200 times the crustal abundance of 0.16 ppm. Cadmium concentrations declined irregularly with depth in the core to $0.6 \mathrm{ppm}$ at $145 \mathrm{~cm}$ (57 in). Below $145 \mathrm{~cm}$, the concentrations remained steady at $0.3 \mathrm{ppm}$, or only twice crustal abundance. It is likely that core GLOC-3 penetrated to material deposited before the deposition of mining-related sediments in the Spring River.

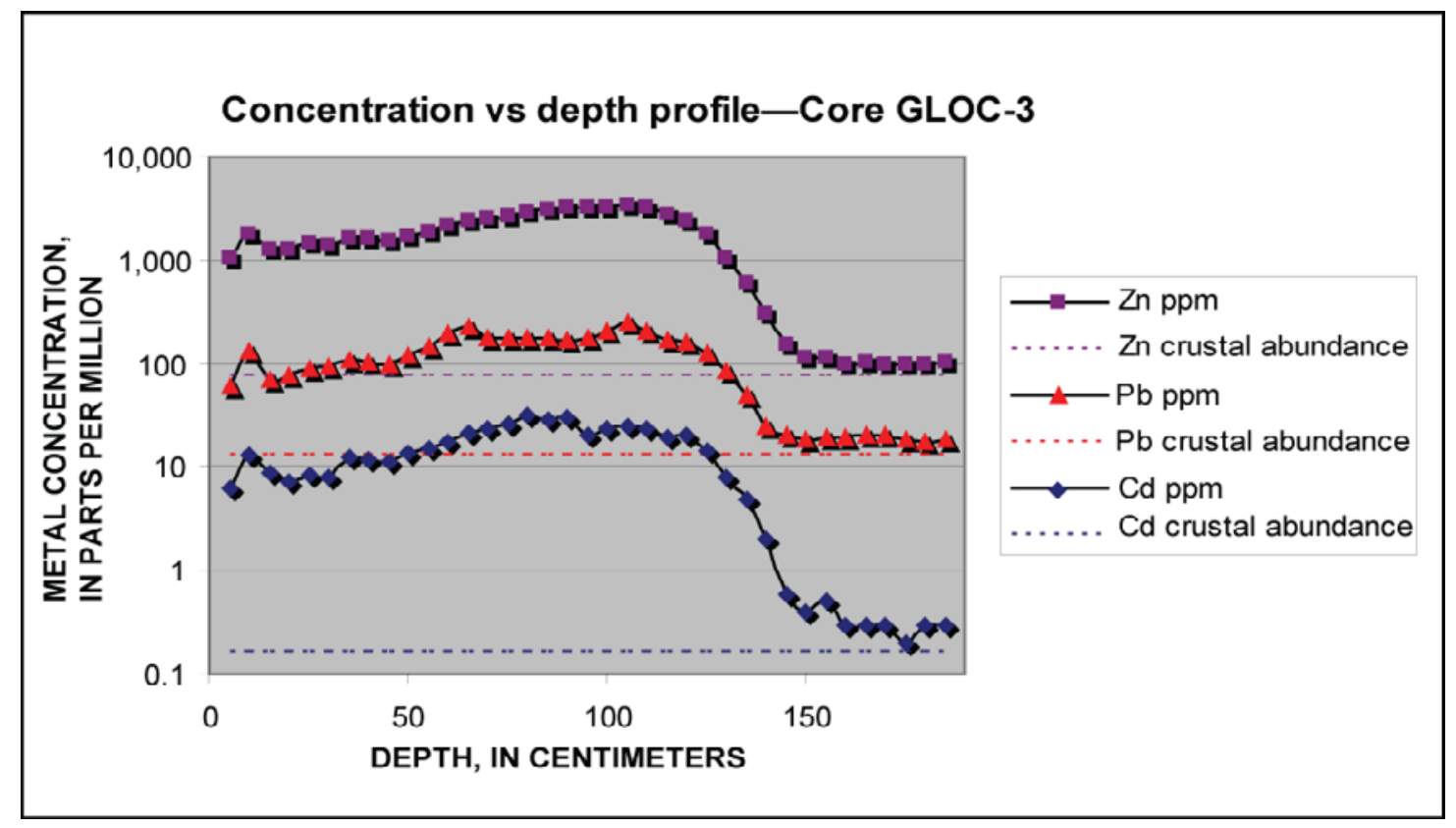

Figure 1-3. Concentration versus depth profile for cadmium $(\mathrm{Cd})$, lead $(\mathrm{Pb})$, and zinc $(\mathrm{Zn})$ for core GLOC-3.

The depth versus concentration profile for lead was similar to that of cadmium. The top $50 \mathrm{~cm}$ (20 in) of sediment had an average lead concentration of about $95 \mathrm{ppm}$, about 6 times crustal abundance, and more than twice the average ratio for all surface sediment. At a depth of $65 \mathrm{~cm}(26 \mathrm{in})$, the lead concentration was $226 \mathrm{ppm}$, after which it decreased to about $170 \mathrm{ppm}$ until a depth of $94 \mathrm{~cm}$ (37 in). The lead concentration increased to $250 \mathrm{ppm}$ at a depth of $105 \mathrm{~cm}$ (41 in), and then decreased to $20 \mathrm{ppm}$, near crustal abundance, from $145 \mathrm{~cm}$ (57 in) to the bottom of the core. The lead data from this core indicate that most of the lead entering the Grand Lake O' the Cherokees is coming from the Spring River.

Similarly, zinc concentrations in this core are greater than those of any other sediment samples. The topmost interval of this core had a zinc concentration of $1,020 \mathrm{ppm}$; the concentrations then increased to $3,340 \mathrm{ppm}$ at a depth of $105 \mathrm{~cm}$ (41 in). Zinc concentrations then decreased to about 100 
ppm from a depth of $145 \mathrm{~cm}$ (57 in) down to the bottom of the core (185 cm [73 in]). The bottom sample concentrations were only 1.4 times crustal abundance, indicating that this core penetrated to below sediments affected by mining. The larger lead and zinc concentrations in this core, relative to those of the core from the Neosho River, GLOC-2, may be related to the fact that a larger percentage of the land area of the Spring River basin had been mined compared to the percentage of area mined in the Neosho River basin.

\section{Core GLOC-7 Grand Lake 0' the Cherokees Reservoir (Table 1-6)}

Core GLOC-7 was collected from a site about $3.5 \mathrm{~km}(2.2 \mathrm{mi})$ downstream from the confluence of the Neosho and Spring Rivers, in the main body of the reservoir. The purpose of collecting this core was to document metal depth versus concentration profiles in Grand Lake O' the Cherokees. Both cadmiuim and zinc showed distinctive profiles. The major element concentration ratios to crustal abundance in this core were similar to those of the surface sediments.

Figure 1-4 shows the concentration versus depth profile for $\mathrm{Cd}, \mathrm{Pb}$, and $\mathrm{Zn}$ for core GLOC-7. Whereas the cadmium concentrations were much less than those from core GLOC-3, they had a distinct bimodal pattern. Between the top of the core and a depth of $70 \mathrm{~cm}(28 \mathrm{in})$, the cadmium concentrations oscillate between 1 and $4 \mathrm{ppm}$. From $70 \mathrm{~cm}$ to the bottom of the core at $135 \mathrm{~cm}(53 \mathrm{in})$, the cadmium concentrations decrease to about $0.4 \mathrm{ppm}$, only 2.6 times crustal abundance. This core penetrated to below mining-affected sediment, possibly into pre-reservoir soil that was flooded and covered with sediment after the completion of the Pensacola Dam.

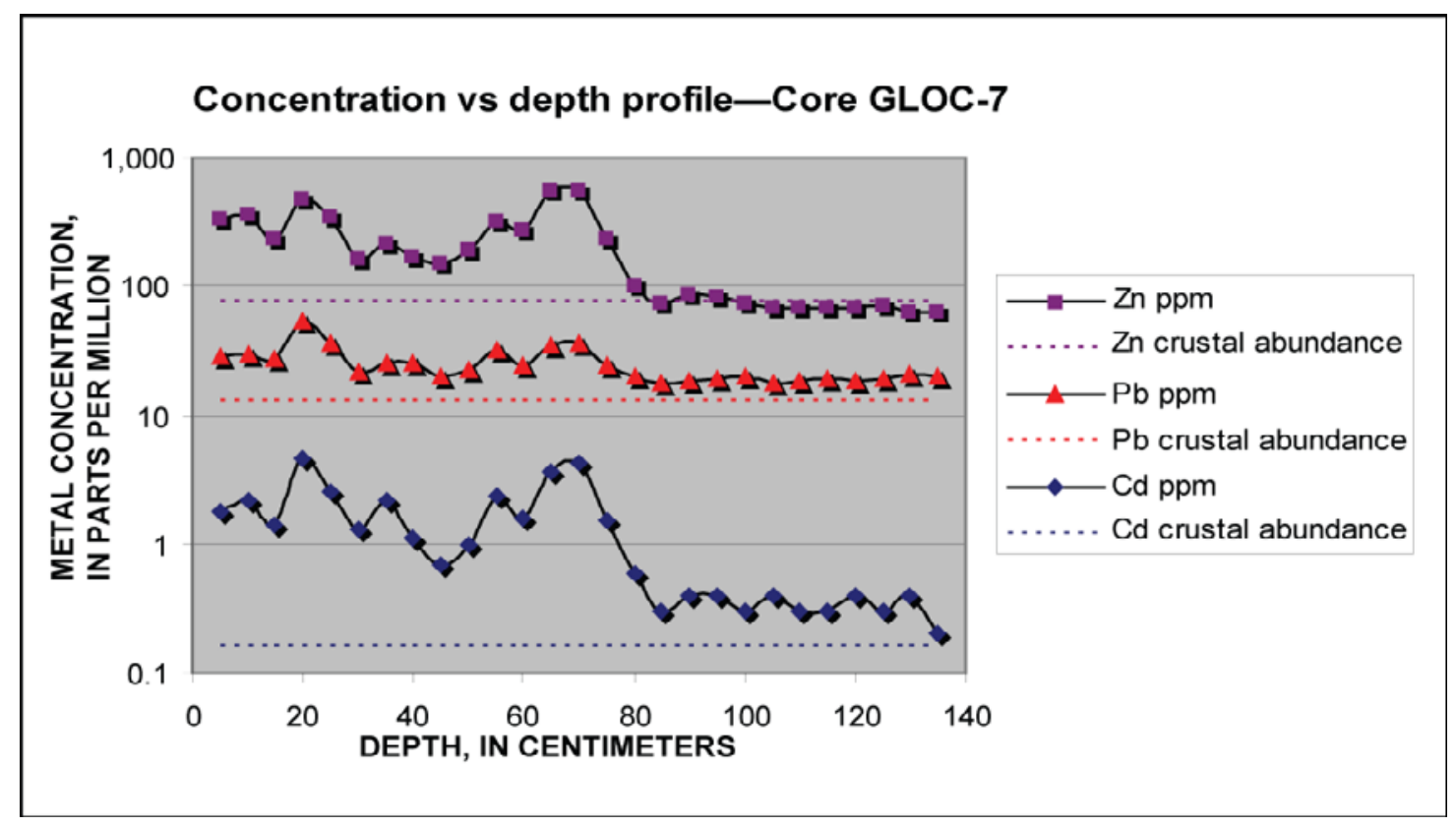

Figure 1-4. Concentration versus depth profile for cadmium (Cd), lead $(\mathrm{Pb})$, and zinc $(\mathrm{Zn})$ for core GLOC-7.

Lead concentrations in core GLOC-7 are not highly elevated above background. Concentrations are irregular between the top interval ( $28 \mathrm{ppm})$, ranging up to $54 \mathrm{ppm}$ at $20-\mathrm{cm}$ (8-in) depth and decreasing to $20 \mathrm{ppm}$ at a depth of $80 \mathrm{~cm}$ (31 in), which is 1.5 times crustal abundance. Despite large concentrations entering the reservoir from the Spring River, the lead concentrations are attenuated by the time sediment reaches GLOC-7, probably due to the immobility of lead. 
Zinc concentrations in core GLOC-7 also had a bimodal distribution, with one depth range of elevated and variable concentrations and a second depth range with values near crustal abundance. Beneath the top sample interval, which has a zinc concentration of $336 \mathrm{ppm}$ (crustal abundance is 76 $\mathrm{ppm}$ ), the zinc concentration profile ranges from a local maximum of $463 \mathrm{ppm}$ at $20-\mathrm{cm}$ (8-in) depth, down to a local minimum of $152 \mathrm{ppm}$ at $45 \mathrm{~cm}$ (18 in), and then up to a core maximum of $554 \mathrm{ppm}$ at 70-cm (28-in) depth, after which the concentrations show a sharp decline. Below 85-cm (33-in) depth, zinc concentration remained about $70 \mathrm{ppm}$, the crustal abundance concentration. The zinc concentration profile, then, also appears to indicate that the core penetrated to pre-reservoir material.

\section{Core GLOC-8 Confluence of Neosho and Spring Rivers (Table 1-7)}

Core GLOC- 8 was collected just off the tip of land that protrudes into the reservoir on the southern end of Twin Bridges State Park. The site was selected to represent a possible mixing zone for sediment from the Neosho and Spring Rivers; however, there may not have been equal contributions of sediment from each river at this site. Metals concentrations of the top three intervals indicate that the Spring River contributes more to the current surface sediment signature (see the previous discussion on bottom-surface sediment). The major element concentration ratios to crustal abundance in this core were similar to those of the surface sediments.

Figure 1-5 shows the concentration versus depth profile for $\mathrm{Cd}, \mathrm{Pb}$, and $\mathrm{Zn}$ for core GLOC-8. The cadmium concentrations at the top three intervals $(15 \mathrm{~cm}$ [6 in]) of this core are about $20 \mathrm{ppm}, 130$ times crustal abundance. At $25-\mathrm{cm}$ (10-in) depth, a maximum of $25 \mathrm{ppm}$ cadmium was measured, followed by a decrease to $3.1 \mathrm{ppm}$ at $50-\mathrm{cm}(20$-in) depth. From $50 \mathrm{~cm}$ to the bottom of the core $(75 \mathrm{~cm}$ [30 in]), cadmium concentrations decreased to $0.7 \mathrm{ppm}$, or about 4.5 times crustal abundance. The background core GLOC-9 had cadmium concentrations of about $0.3 \mathrm{ppm}$, so it appears that core GLOC-8 cadmium concentrations were approaching local background concentrations near the base.

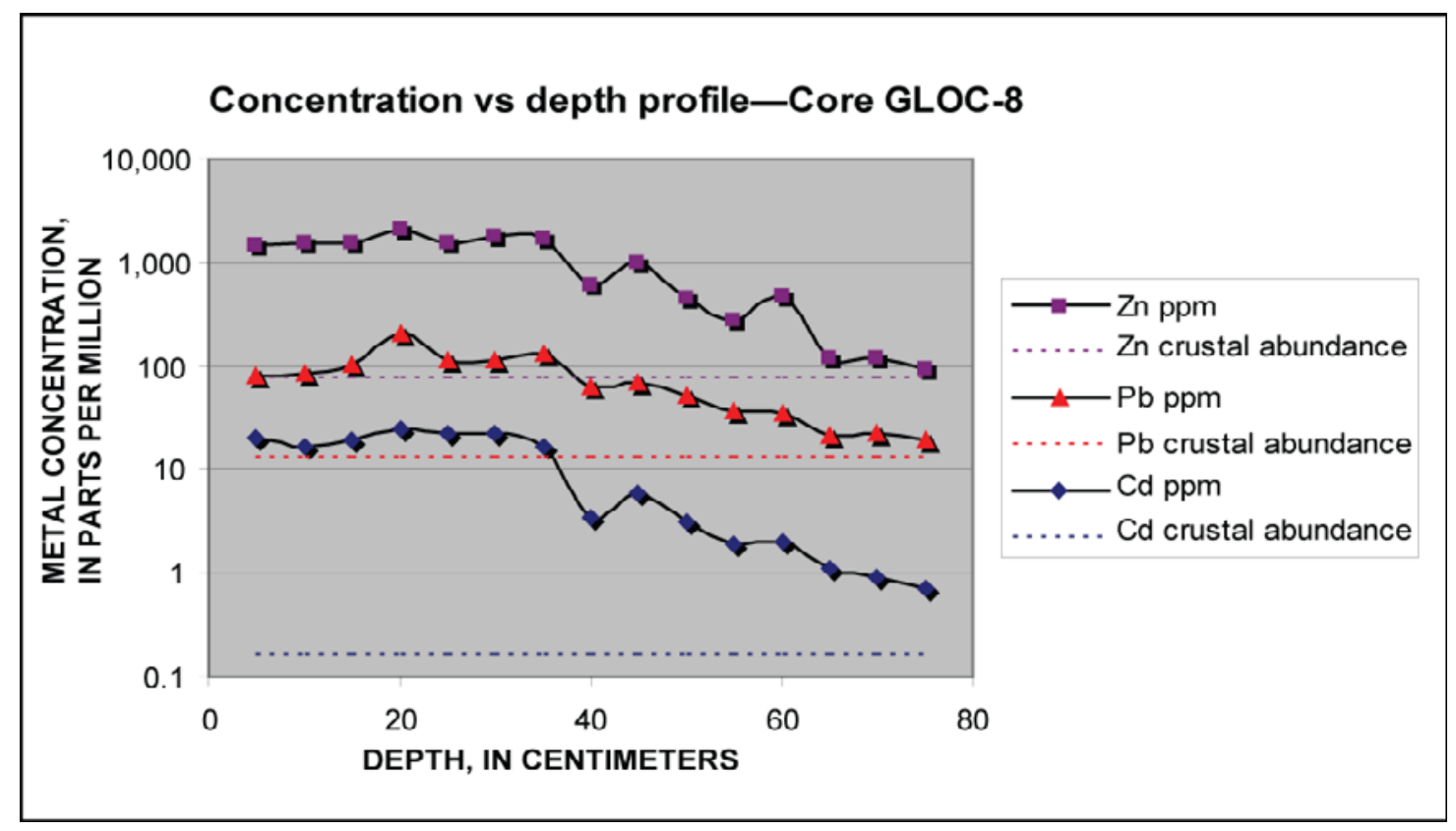

Figure 1-5. Concentration versus depth profile for cadmium (Cd), lead $(\mathrm{Pb})$, and zinc $(\mathrm{Zn})$ for core GLOC-8. 
Lead concentrations in core GLOC-8 were also elevated, relative to background. This site is only $1.6 \mathrm{~km}$ (1 mi) downstream from GLOC-3, the Spring River core. The first three intervals of this core averaged $90 \mathrm{ppm}$ lead, followed by a maximum of $204 \mathrm{ppm}$ at a depth of $20 \mathrm{~cm}(8 \mathrm{in})$. The maximum lead concentration from the Spring River core (GLOC-3) was $250 \mathrm{ppm}$. From 20-cm depth to the core bottom at $75 \mathrm{~cm}$ (30 in), there is an irregular decrease in lead concentrations, with the bottom three intervals containing 20 ppm, or just 1.4 times crustal abundance.

Zinc concentrations in the upper $60 \mathrm{~cm}$ (24 in) of core GLOC-8 were much greater than background concentrations. The top three intervals of this core contained about $1,500 \mathrm{ppm}$ zinc, with a concentration of 2,030 ppm occurring at a depth of $20 \mathrm{~cm}(8 \mathrm{in})$. The relatively large zinc concentrations in this core appear to be contributed mostly by sediment from the Spring River, since GLOC-2, the core from the Neosho River, contained smaller zinc concentrations than core GLOC-8. Between depths of 25 and $35 \mathrm{~cm}$ (10-14 in), the zinc concentration in core GLOC-8 averaged 1,690 ppm and then decreased irregularly to $478 \mathrm{ppm}$ at a depth of $60 \mathrm{~cm}$ (24 in). In the last three depth intervals, 65 to $75 \mathrm{~cm}(26-30$ in), the zinc concentration in this core averaged $110 \mathrm{ppm}$, which may be a result of the core's having penetrated to below mining-affected sediment.

\section{Summary and Conclusion}

Grand Lake O' the Cherokees is a reservoir downstream from the Tri-State District of Oklahoma, Kansas, and Missouri. This is a Mississippi Valley-type deposit, formerly one of the largest producers of lead and zinc in the world. Sediment core samples and bottom sediment samples were collected from the reservoir and from the Neosho River and the Spring River and analyzed to assess their geochemical signatures.

The Elk River arm (core GLOC-9) to the reservoir defines local background concentrations for the metals $\mathrm{Zn}, \mathrm{Pb}, \mathrm{Cd}, \mathrm{As}$, and $\mathrm{Cu}$. The background for zinc was $52 \mathrm{ppm}$, which is less than the crustal abundance of $76 \mathrm{ppm}$. The local background for lead was $16 \mathrm{ppm}$, similar to the crustal abundance concentration of $13 \mathrm{ppm}$. The local background concentration for cadmium was $0.3 \mathrm{ppm}$, about twice that of the crustal abundance of $0.16 \mathrm{ppm}$. The local background concentration for arsenic was $4.2 \mathrm{ppm}$, compared to $1.8 \mathrm{ppm}$ crustal abundance. Copper had a background concentration of $12 \mathrm{ppm}$, compared to $68 \mathrm{ppm}$ crustal abundance.

The sediment samples collected from the sediment-water interface had larger average concentrations of $\mathrm{Zn}, \mathrm{Cd}$, and $\mathrm{Pb}$ than local background. The zinc concentrations of the bottomsediment samples averaged 500 ppm, or almost 10 times the local background. The bottom-sediment lead concentrations averaged $42 \mathrm{ppm}$, about 2.6 times the local background. The cadmium concentrations of the bottom-sediment samples averaged $2.5 \mathrm{ppm}$, about 8 times local background. Locally, terrestrial sediment input into the upper parts of some coves can dilute the sediment signature.

The Spring River core GLOC-3 had the largest concentrations of mining-related elements. These concentrations were larger than those from the Neosho River core GLOC-2, possibly related to the fact that a larger percentage of the land area in the Spring River basin was mined compared to the percentage mined in the Neosho River Basin. The core collected from just south of Twin Bridges State Park, core GLOC-8 at the confluence of the Spring and Neosho Rivers, showed a mixing zone with more miningrelated elements coming from the Spring River side.

The element zinc showed the most definitive patterns in concentration versus depth profiles. The core collected from the main body of the reservoir, GLOC-7, showed affected sediment down to a depth of $85 \mathrm{~cm}$ (33 in), below which mining-related element concentrations approached local background levels. This core and cores GLOC-3 and GLOC-8 appear to have penetrated to below mining-affected sediment. 


\section{Acknowledgments}

We were assisted in the collection of the sediment cores and bottom-sediment samples by Ernie Smith of the USGS Oklahoma Water Science Center. Rhonda Driscoll at the USGS Denver Federal Center laboratories performed X-ray diffraction (XRD) mineralogical analyses on selected samples. Sample handling, preparation, and shipping from the Denver Federal Center laboratories were performed by USGS personnel David Walters and Murray Beasley. The USGS Central Region Interdisciplinary Science Program (CRISP) provided funding for the project. Reviews by Warren Day and William Andrews of the USGS provided significant improvements.

\section{References}

Andrews, W.J., Becker, M.F., Mashburn, S.L., and Smith, S.J., 2009, Selected metals in sediments and streams in the Oklahoma part of the Tri-State Mining District, 2000-06: U.S. Geological Survey Scientific Investigations Report 2009-5032, 36 p.

Briggs, P.H., 2002, The determination of forty elements in geological and botanical samples by inductively coupled plasma-atomic emission spectrometry, chap. G of Taggart, J.E., ed., Analytical methods for chemical analysis of geologic and other materials: U.S. Geological Survey Open-File Report 02-0223, 18 p.

Briggs, P.H., and Meier, A.L., 2002, The determination of forty-two elements in geological materials by inductively coupled plasma-mass spectrometry, chap. I of Taggart, J.E., ed., Analytical methods for chemical analysis of geologic and other materials: U.S. Geological Survey Open-File Report 020223, 14 p.

Brosius, Liz, and Sawin, R.S., 2001, Lead and zinc mining in Kansas: Kansas Geological Survey Public Information Circular 17, $6 \mathrm{p}$.

Brown, Z.A., and Curry, K.J., 2002, Total carbon by combustion, chap. R of Taggart, J.E., ed., Analytical methods for chemical analysis of geologic and other materials: U.S. Geological Survey Open-File Report 02-0223, 4 p.

Brown, Z.A., Papp, C., Brandt, E., and Aruscavage, P., 2002, Carbonate carbon by coulometric titration, chap S of Taggart, J.E., ed., Analytical methods for chemical analysis of geologic and other materials: U.S. Geological Survey Open-File Report 02-0223, 6 p.

Carroll, S.A., O’Day, P.A., and Piechowski, M., 1998, Rock-water interactions controlling zinc, cadmium, and lead concentrations in surface waters and sediments, U.S. Tri-State Mining District-2. Geochemical interpretation: Environmental Science and Technology, v. 32, p. 956-965.

Church, S.E., Mosier, E.L., and Motooka, J.M., 1987, Mineralogical basis for the interpretation of multielement (ICP-AES), oxalic acid, and aqua-regia partial digestions of stream sediments for reconnaissance exploration geochemistry: Journal of Geochemical Exploration, v. 29, p. 207-233.

Dux, J.P., 1986, Handbook of quality assurance for the Analytical Chemistry Laboratory: New York, Van Nostrand Reinhold Company Inc., 123 p.

Erickson, B.M., Harms, T.F., and Filipek, L.H., 1988, Problems associated with analyses of plant samples in the Tar Creek study, in Ragone, S.E., ed., U.S. Geological Survey Program on Toxic Waste-Groundwater Contamination-Proceedings of the second technical meeting, Cape Cod, Massachussetts, October 21-25, 1985: U.S. Geological Survey Open-File Report 86-481, p. D-17-D20.

Fey, D.L., Granitto, M., Giles, S.A., Smith, S.G., Eppinger, R.G., and Kelley, K.D., 2009, Geochemical data for samples collected in 2008 near the concealed Pebble porphyry Cu-Au-Mo deposit, southwest 
Alaska: U.S. Geological Survey Open-File Report 2009-1239, 120 p., (also available at http://pubs.usgs.gov/of/2009/1239/).

Fortescue, J.A.C., 1992, Landscape geochemistry-Retrospect and prospect-1990: Applied Geochemistry, v. 7, p 1-54.

Gibson, A.M., 1982, Lead and zinc, in Morris, J.W., ed., Drill bits, picks, and shovels-A history of mineral resources in Oklahoma: Oklahoma City, Okla., Oklahoma Historical Society, 201 p.

Juracek, K.E., 2006, Sedimentation and occurrence and trends of selected chemical constituents in bottom sediment, Empire Lake, Cherokee County, Kansas, 1905-2005: U.S. Geological Survey Scientific Investigations Report 2006-5307, 79 p.

Juracek, K.E., and Becker, M.F., 2009, Occurrence and trends of selected chemical constituents in bottom sediment, Grand Lake O' the Cherokees, Northeast Oklahoma, 1940-2008: U.S. Geological Survey Scientific Investigations Report 2009-5258, 28 p.

Parkhurst, D.L., 1987, Chemical analyses of water samples from the Picher mining area, northeast Oklahoma and southeast Kansas: U.S. Geological Survey Open-File Report 87-453, 43p.

Parkhurst, D.L., 1988, Mine-water discharge, metal loading, and chemical reactions, in Ragone, S.E., ed., U.S. Geological Survey Program on Toxic Waste-Groundwater Contamination-Proceedings of the second technical meeting, Cape Cod, Massachussetts, October 21-25, 1985: U.S. Geological Survey Open-File Report 86-481, p. D-5-D-9.

Parkhurst, D.L., Doughten, Michael, and Hearn, P.P., 1988, Chemical analyses of stream sediment in the Tar Creek basin of the Picher mining area, northeast Oklahoma: U.S. Geological Survey OpenFile Report 88-469, 18 p.

Pope, L.M., 2005, Assessment of contaminated streambed sediment in the Kansas part of the historic Tri-State Lead and Zinc Mining District, Cherokee County, 2004: U.S. Geological Survey Scientific Investigations Report 2005-5251, $61 \mathrm{p}$.

Rose, A.W., Hawkes, H.E., and Webb, J.S., 1979, Geochemistry in mineral exploration (2d ed.): New York, Academic Press, $657 \mathrm{p}$.

Smith, K.S., Filipek, L.H., Updegraff, D.M., and Papp, C.S.E, 1988, Distribution of microorganisms and selected metals in mine drainage, stream water, and sediment, in Ragone, S.E., ed., U.S. Geological Survey Program on Toxic Waste-Groundwater Contamination-Proceedings of the second technical meeting, Cape Cod, Massachussetts, October 21-25, 1985: U.S. Geological Survey Open-File Report 86-481, p. D-11-D-15.

State of Oklahoma, 2000, Governor Frank Keating's Tar Creek Superfund Task Force-Final Report, 1 October 2000: State of Oklahoma, Office of the Secretary of the Environment, 26 p.

Stumm, W., and Morgan, J.J., 1981, Aquatic chemistry: New York, John Wiley and Sons, 780 p.

Wilson, S.A., Briggs, P.H., Mee, J.S., and Siems, D.F., 1994, Determinations of thirty-two major and trace elements in three NIST soil SRMs using ICP-AES and WDXRF: Geostandards Newsletter, v. 18 , p. $85-89$.

Weast, R.C., 1978, Handbook of chemistry and physics (58th ed.): Cleveland, Ohio, CRC Press, Inc., p. B-254. 


\section{Appendix 1. Analytical Data}

Table 1-1. Elements analyzed, instrument used, reporting limits, and mean of eight procedure blanks for four-acid digestion procedure. (Click to see Excel file.)

[ICP-AES, inductively coupled plasma-atomic emission spectroscopy; ICP-MS, inductively coupled plasma-mass spectroscopy; \%, percent; ppm, parts per million; n/a, not available]

\begin{tabular}{lllcc}
\hline Element & Instrument & Unit & $\begin{array}{c}\text { Reporting } \\
\text { limit }\end{array}$ & $\begin{array}{c}\text { Blank mean } \\
(\mathbf{n}=8)\end{array}$ \\
\hline Carb C & Coulometric & percent & 0.003 & $<0.003$ \\
Total C & Combustion & percent & 0.01 & $\mathrm{n} / \mathrm{a}$ \\
$\mathrm{Al}$ & ICP-AES & percent & 0.01 & $<0.01$ \\
$\mathrm{Ca}$ & ICP-AES & percent & 0.01 & $<0.01$ \\
$\mathrm{Fe}$ & ICP-AES & percent & 0.01 & $<0.01$ \\
$\mathrm{~K}$ & ICP-AES & percent & 0.01 & $<0.01$ \\
$\mathrm{Mg}$ & ICP-AES & percent & 0.01 & $<0.01$ \\
$\mathrm{Na}$ & ICP-AES & percent & 0.01 & $<0.01$ \\
$\mathrm{~S}$ & ICP-AES & percent & 0.01 & $<0.01$ \\
$\mathrm{Ti}$ & ICP-AES & percent & 0.01 & $<0.01$ \\
$\mathrm{As}$ & ICP-MS & ppm & 1.0 & $<1$ \\
$\mathrm{Ba}$ & ICP-AES & ppm & 5.0 & $<5$ \\
$\mathrm{Bi}$ & ICP-MS & ppm & 0.04 & $<0.04$ \\
$\mathrm{Cd}$ & ICP-MS & ppm & 0.1 & $<0.1$ \\
$\mathrm{Co}$ & ICP-MS & ppm & 0.1 & 0.2 \\
$\mathrm{Cr}$ & ICP-AES & ppm & 1.0 & 2.0 \\
$\mathrm{Cu}$ & ICP-AES & ppm & 0.5 & 0.65 \\
$\mathrm{Ga}$ & ICP-MS & ppm & 0.05 & 0.06 \\
$\mathrm{In}$ & ICP-MS & ppm & 0.02 & $<0.02$ \\
$\mathrm{Li}$ & ICP-AES & ppm & 1.0 & $<1$ \\
$\mathrm{Mn}$ & ICP-AES & ppm & 5.0 & $<5$ \\
$\mathrm{Ni}$ & ICP-AES & ppm & 0.5 & 0.60 \\
$\mathrm{P}$ & ICP-AES & ppm & 50 & $<50$ \\
$\mathrm{~Pb}$ & ICP-MS & ppm & 0.5 & 0.80 \\
$\mathrm{Rb}$ & ICP-MS & ppm & 0.2 & 0.30 \\
$\mathrm{Sr}$ & ICP-AES & ppm & 0.5 & $<0.5$ \\
$\mathrm{~V}$ & ICP-AES & ppm & 1.0 & $<1$ \\
$\mathrm{Zn}$ & ICP-AES & ppm & 1.0 & $<1$ \\
\hline & & & & \\
\hline
\end{tabular}


Table 1-2. Grand Lake O' the Cherokees bottom-sediment sample analyses. Analyses by ICP-AES/MS after fouracid digestion, except for forms of carbon. First five samples are composites of top three intervals of cores GLOC2, GLOC-3, GLOC-7, GLOC-8, and GLOC-9. (Click to see Excel file.)

[ICP-AES/MS, inductively coupled plasma-atomic emission spectroscopy/mass spectroscopy; \%, percent; ppm, parts per million]

\begin{tabular}{ccccccccc}
\hline & & Total C & Carbonate C & Organic C & Al & Ca & Fe & K \\
Lab no. & Field no. & $\%$ & $\%$ & $\%$ & $\%$ & $\%$ & $\%$ & $\%$ \\
\hline composite & GLOC-2_1-7 & 1.01 & 0.04 & 0.97 & 5.35 & 0.62 & 2.26 & 1.54 \\
composite & GLOC-3_1-7 & 1.39 & 0.08 & 1.30 & 2.87 & 0.48 & 1.65 & 0.71 \\
composite & GLOC-7_1-7 & 1.68 & 0.04 & 1.65 & 6.60 & 0.85 & 2.95 & 1.43 \\
composite & GLOC-8_1-7 & 1.13 & 0.01 & 1.11 & 5.20 & 0.473 & 2.35 & 1.32 \\
composite & GLOC-9_1-7 & 1.54 & 0.24 & 1.30 & 2.82 & 1.02 & 1.16 & 0.99 \\
C-310716 & GLOC-12_1-7 & 1.79 & 0.02 & 1.77 & 7.39 & 0.83 & 3.46 & 1.67 \\
C-310690 & GLOC-13_1-7 & 1.25 & 0.01 & 1.24 & 4.81 & 0.62 & 2.08 & 1.10 \\
C-310708 & GLOC-14_1-7 & 2.01 & 0.08 & 1.93 & 7.60 & 1.09 & 3.3 & 1.55 \\
C-310685 & GLOC-15_1-7 & 1.99 & 0.02 & 1.97 & 8.11 & 0.94 & 3.91 & 1.76 \\
C-310703 & GLOC-16_1-7 & 1.98 & 0.19 & 1.79 & 4.89 & 1.23 & 2.22 & 1.27 \\
C-310681 & GLOC-17_1-7 & 1.77 & 0.04 & 1.73 & 7.41 & 0.94 & 3.51 & 1.69 \\
C-310713 & GLOC-18_1-7 & 1.29 & 0.03 & 1.26 & 5.69 & 0.65 & 2.39 & 1.59 \\
C-310707 & GLOC-19_1-7 & 1.76 & 0.03 & 1.73 & 7.71 & 0.89 & 3.57 & 1.70 \\
C-310688 & GLOC-20_1-7 & 1.78 & 0.01 & 1.77 & 3.33 & 0.41 & 1.64 & 0.90 \\
C-310702 & GLOC-21_1-7 & 2.05 & 0.10 & 1.95 & 8.32 & 1.26 & 3.92 & 1.77 \\
C-310684 & GLOC-22_1-7 & 1.57 & 0.02 & 1.55 & 7.58 & 0.83 & 3.45 & 1.77 \\
C-310700 & GLOC-23_1-7 & 0.86 & 0.01 & 0.85 & 4.37 & 0.32 & 1.81 & 1.15 \\
C-310693 & GLOC-24_1-7 & 1.36 & 0.06 & 1.30 & 4.68 & 0.71 & 2.15 & 1.31 \\
C-310712 & GLOC-25_1-7 & 1.36 & 0.02 & 1.34 & 5.93 & 0.61 & 2.57 & 1.57 \\
C-310710 & GLOC-26_1-7 & 4.58 & 0.23 & 4.35 & 6.14 & 1.74 & 3.12 & 1.47
\end{tabular}


Table 1-2. Grand Lake O' the Cherokees bottom-sediment sample analyses. Analyses by ICP-AES/MS after fouracid digestion, except for forms of carbon. First five samples are composites of top three intervals of cores GLOC2, GLOC-3, GLOC-7, GLOC-8, and GLOC-9.-Continued

[ICP-AES/MS, inductively coupled plasma-atomic emission spectroscopy/mass spectroscopy; \%, percent; ppm, parts per million]

\begin{tabular}{|c|c|c|c|c|c|c|c|c|}
\hline Lab no. & Field no. & $\begin{array}{c}\mathrm{Mg} \\
\% \\
\end{array}$ & $\begin{array}{c}\mathrm{Na} \\
\% \\
\end{array}$ & $\begin{array}{l}\mathbf{S} \\
\%\end{array}$ & $\begin{array}{l}\mathrm{Ti} \\
\%\end{array}$ & $\begin{array}{c}\text { As } \\
\mathrm{ppm}\end{array}$ & $\begin{array}{c}\mathrm{Ba} \\
\mathrm{ppm}\end{array}$ & $\begin{array}{c}\mathrm{Bi} \\
\mathrm{ppm}\end{array}$ \\
\hline composite & GLOC-2_1-7 & 0.45 & 0.64 & 0.03 & 0.23 & 6 & 500 & 0.23 \\
\hline composite & GLOC-3_1-7 & 0.17 & 0.23 & 0.07 & 0.15 & 4 & 269 & 0.16 \\
\hline composite & GLOC-7_1-7 & 0.35 & 0.65 & 0.05 & 0.21 & 6 & 450 & 0.19 \\
\hline composite & GLOC-8_1-7 & 0.38 & 0.46 & 0.04 & 0.24 & 7 & 465 & 0.27 \\
\hline composite & GLOC-9_1-7 & 0.19 & 0.22 & 0.04 & 0.17 & 3 & 297 & 0.14 \\
\hline C-310716 & GLOC-12_1-7 & 0.63 & 0.33 & 0.12 & 0.31 & 10 & 547 & 0.33 \\
\hline C-310690 & GLOC-13_1-7 & 0.34 & 0.30 & 0.16 & 0.23 & 7 & 414 & 0.28 \\
\hline C-310708 & GLOC-14_1-7 & 0.62 & 0.24 & 0.19 & 0.29 & 10 & 532 & 0.35 \\
\hline C-310685 & GLOC-15_1-7 & 0.71 & 0.32 & 0.11 & 0.30 & 10 & 604 & 0.36 \\
\hline C-310703 & GLOC-16_1-7 & 0.36 & 0.28 & 0.14 & 0.22 & 8 & 434 & 0.22 \\
\hline C-310681 & GLOC-17_1-7 & 0.64 & 0.38 & 0.12 & 0.25 & 10 & 574 & 0.34 \\
\hline C-310713 & GLOC-18_1-7 & 0.46 & 0.60 & 0.07 & 0.26 & 7 & 500 & 0.25 \\
\hline C-310707 & GLOC-19_1-7 & 0.66 & 0.35 & 0.13 & 0.30 & 11 & 566 & 0.33 \\
\hline C-310688 & GLOC-20_1-7 & 0.23 & 0.24 & 0.09 & 0.19 & 6 & 338 & 0.18 \\
\hline C-310702 & GLOC-21_1-7 & 0.74 & 0.27 & 0.17 & 0.28 & 13 & 577 & 0.36 \\
\hline C-310684 & GLOC-22_1-7 & 0.67 & 0.42 & 0.11 & 0.28 & 9 & 583 & 0.34 \\
\hline C-310700 & GLOC-23_1-7 & 0.25 & 0.41 & 0.03 & 0.24 & 5 & 487 & 0.20 \\
\hline C-310693 & GLOC-24_1-7 & 0.36 & 0.32 & 0.08 & 0.23 & 7 & 447 & 0.23 \\
\hline C-310712 & GLOC-25_1-7 & 0.49 & 0.53 & 0.06 & 0.24 & 7 & 518 & 0.27 \\
\hline C-310710 & GLOC-26_1-7 & 0.56 & 0.32 & 0.33 & 0.24 & 16 & 511 & 0.36 \\
\hline
\end{tabular}


Table 1-2. Grand Lake O' the Cherokees bottom-sediment sample analyses. Analyses by ICP-AES/MS after fouracid digestion, except for forms of carbon. First five samples are composites of top three intervals of cores GLOC2, GLOC-3, GLOC-7, GLOC-8, and GLOC-9.-Continued

[ICP-AES/MS, inductively coupled plasma-atomic emission spectroscopy/mass spectroscopy; \%, percent; ppm, parts per million]

\begin{tabular}{clcccccccc}
\hline Lab no. & Field no. & $\begin{array}{c}\text { Cd } \\
\text { ppm }\end{array}$ & $\begin{array}{c}\text { Co } \\
\text { ppm }\end{array}$ & $\begin{array}{c}\text { Cr } \\
\text { ppm }\end{array}$ & $\begin{array}{c}\text { Cu } \\
\text { ppm }\end{array}$ & $\begin{array}{c}\text { Ga } \\
\text { ppm }\end{array}$ & $\begin{array}{c}\text { In } \\
\text { ppm }\end{array}$ & $\begin{array}{c}\text { Li } \\
\text { ppm }\end{array}$ & $\begin{array}{c}\text { Mn } \\
\text { ppm }\end{array}$ \\
\hline composite & GLOC-2_1-7 & 0.43 & 11 & 51 & 15.0 & 13 & 0.04 & 30 & 488 \\
composite & GLOC-3_1-7 & 9.2 & 9.3 & 34 & 16.5 & 6.93 & 0.04 & 20 & 543 \\
composite & GLOC-7_1-7 & 1.8 & 8.9 & 40 & 16.6 & 10.5 & 0.04 & 25 & 378 \\
composite & GLOC-8_1-7 & 19 & 11.3 & 50 & 23.0 & 11.9 & 0.07 & 31 & 534 \\
composite & GLOC-9_1-7 & 0.40 & 7.7 & 40 & 11.5 & 6.0 & 0.02 & 17 & 307 \\
C-310716 & GLOC-12_1-7 & 3.1 & 13.9 & 67 & 25.5 & 17 & 0.06 & 48 & 647 \\
C-310690 & GLOC-13_1-7 & 1.7 & 9.5 & 57 & 19.5 & 10.5 & 0.04 & 31 & 346 \\
C-310708 & GLOC-14_1-7 & 2.3 & 14.0 & 77 & 24.5 & 17.6 & 0.07 & 49 & 382 \\
C-310685 & GLOC-15_1-7 & 2.7 & 14.2 & 74 & 26.7 & 18.4 & 0.07 & 52 & 1,040 \\
C-310703 & GLOC-16_1-7 & 2.2 & 11.9 & 54 & 19.9 & 11.2 & 0.04 & 31 & 510 \\
C-310681 & GLOC-17_1-7 & 3.4 & 14.5 & 77 & 27.1 & 17.3 & 0.07 & 47 & 859 \\
C-310713 & GLOC-18_1-7 & 2.8 & 10.5 & 48 & 18.2 & 12.1 & 0.05 & 34 & 503 \\
C-310707 & GLOC-19_1-7 & 3.4 & 14.4 & 69 & 25.1 & 18.0 & 0.07 & 50 & 735 \\
C-310688 & GLOC-20_1-7 & 0.70 & 8.1 & 38 & 13.8 & 7.3 & 0.03 & 22 & 281 \\
C-310702 & GLOC-21_1-7 & 2.8 & 16.3 & 137 & 30.0 & 20.1 & 0.08 & 54 & 690 \\
C-310684 & GLOC-22_1-7 & 3.0 & 13.8 & 65 & 25.9 & 17.0 & 0.07 & 48 & 603 \\
C-310700 & GLOC-23_1-7 & 1.0 & 11.2 & 39 & 14.1 & 9.9 & 0.04 & 26 & 559 \\
C-310693 & GLOC-24_1-7 & 2.7 & 12.7 & 38 & 18.9 & 10.8 & 0.04 & 30 & 503 \\
C-310712 & GLOC-25_1-7 & 2.7 & 11.1 & 53 & 22.2 & 13.0 & 0.05 & 35 & 514 \\
C-310710 & GLOC-26_1-7 & 3.8 & 22.2 & 63 & 30.0 & 14.1 & 0.06 & 40 & 795
\end{tabular}


Table 1-2. Grand Lake O' the Cherokees bottom-sediment sample analyses. Analyses by ICP-AES/MS after fouracid digestion, except for forms of carbon. First five samples are composites of top three intervals of cores GLOC2, GLOC-3, GLOC-7, GLOC-8, and GLOC-9.-Continued

[ICP-AES/MS, inductively coupled plasma-atomic emission spectroscopy/mass spectroscopy; \%, percent; ppm, parts per million]

\begin{tabular}{cccccccrr}
\hline Lab no. & Field no. & $\begin{array}{c}\text { Ni } \\
\text { ppm }\end{array}$ & $\begin{array}{c}\text { P } \\
\text { ppm }\end{array}$ & $\begin{array}{c}\text { Pb } \\
\text { ppm }\end{array}$ & $\begin{array}{c}\text { Rb } \\
\text { ppm }\end{array}$ & $\begin{array}{c}\text { Sr } \\
\text { ppm }\end{array}$ & $\begin{array}{c}\text { V } \\
\text { ppm }\end{array}$ & $\begin{array}{c}\text { Zn } \\
\text { ppm }\end{array}$ \\
\hline composite & GLOC-2_1-7 & 22.0 & 607 & 20.2 & 90.0 & 113 & 78 & 122 \\
composite & GLOC-3_1-7 & 16.4 & 733 & 87.0 & 46.8 & 42.0 & 45 & 1,370 \\
composite & GLOC-7_1-7 & 18.6 & 530 & 28.3 & 77.3 & 92.7 & 65 & 310 \\
composite & GLOC-8_1-7 & 24.7 & 747 & 90.0 & 82.0 & 75.0 & 79 & 1,523 \\
composite & GLOC-9_1-7 & 22.2 & 357 & 17.0 & 49.0 & 39.3 & 42 & 56 \\
C-310716 & GLOC-12_1-7 & 33.0 & 970 & 46.9 & 117 & 103 & 119 & 574 \\
C-310690 & GLOC-13_1-7 & 28.1 & 560 & 34.4 & 71.5 & 69.4 & 73 & 402 \\
C-310708 & GLOC-14_1-7 & 34.8 & 840 & 47.0 & 119 & 94.5 & 120 & 540 \\
C-310685 & GLOC-15_1-7 & 34.6 & 1,370 & 45.2 & 118 & 107 & 127 & 516 \\
C-310703 & GLOC-16_1-7 & 26.1 & 650 & 37.0 & 80.1 & 78.7 & 77 & 448 \\
C-310681 & GLOC-17_1-7 & 34.2 & 1,020 & 48.9 & 111 & 106 & 115 & 562 \\
C-310713 & GLOC-18_1-7 & 23.4 & 680 & 36.2 & 87.7 & 100 & 82 & 450 \\
C-310707 & GLOC-19_1-7 & 33.2 & 1,150 & 46.4 & 123 & 109 & 118 & 577 \\
C-310688 & GLOC-20_1-7 & 17.4 & 600 & 22.4 & 58.9 & 51.5 & 57 & 242 \\
C-310702 & GLOC-21_1-7 & 72.2 & 1,170 & 46.2 & 132 & 114 & 135 & 550 \\
C-310684 & GLOC-22_1-7 & 32.1 & 950 & 42.1 & 112 & 113 & 116 & 528 \\
C-310700 & GLOC-23_1-7 & 19.9 & 360 & 21.2 & 75.3 & 68.3 & 62 & 134 \\
C-310693 & GLOC-24_1-7 & 22.0 & 670 & 37.1 & 76.0 & 78.1 & 73 & 478 \\
C-310712 & GLOC-25_1-7 & 25.1 & 790 & 36.9 & 92.5 & 97.4 & 85 & 473 \\
C-310710 & GLOC-26_1-7 & 40.2 & 1,360 & 76.2 & 97.9 & 108 & 122 & 1,020 \\
\hline
\end{tabular}


Table 1-3. Core sediment background sample analyses for GLOC-9, Elk River arm of Grand Lake O' the Cherokees. Analyses by ICP-AES/MS after four-acid digestion, except for forms of carbon. (Click to see Excel file.) [ICP-AES/MS, inductively coupled plasma-atomic emission spectroscopy/mass spectroscopy; cm, centimeter; \%, percent; ppm, parts per million]

\begin{tabular}{|c|c|c|c|c|c|c|c|c|c|}
\hline Lab no. & Field no. & $\begin{array}{c}\text { Depth in } \\
\text { inches }\end{array}$ & $\begin{array}{l}\text { Depth } \\
\text { in cm }\end{array}$ & $\begin{array}{l}\text { Total } \\
\mathrm{C} \% \\
\end{array}$ & $\begin{array}{c}\text { Carbonate } \\
\text { C \% }\end{array}$ & $\begin{array}{c}\text { Organic } \\
\mathrm{C} \%\end{array}$ & Al \% & Ca $\%$ & $\mathrm{Fe} \%$ \\
\hline C-310665 & GLOC-9_1-3 & 2 & 5 & 1.6 & 0.31 & 1.29 & 2.71 & 1.23 & 1.13 \\
\hline C-310655 & GLOC-9_3-5 & 4 & 10 & 1.53 & 0.23 & 1.3 & 2.94 & 0.99 & 1.19 \\
\hline C-310627 & GLOC-9_5-7 & 6 & 15 & 1.49 & 0.19 & 1.3 & 2.82 & 0.84 & 1.15 \\
\hline C-310670 & GLOC-9_7-9 & 8 & 20 & 1.47 & 0.2 & 1.27 & 2.67 & 0.88 & 1.04 \\
\hline C-310671 & GLOC-9_9-11 & 10 & 25 & 1.35 & 0.19 & 1.16 & 2.47 & 0.83 & 1.02 \\
\hline C-310661 & GLOC-9 $11-13$ & 12 & 30 & 1.42 & 0.18 & 1.24 & 2.7 & 0.78 & 1.09 \\
\hline C-310650 & GLOC-9_13-15 & 14 & 35 & 1.41 & 0.11 & 1.3 & 2.66 & 0.58 & 1.11 \\
\hline C-310642 & GLOC-9-15-17 & 16 & 40 & 1.6 & 0.1 & 1.5 & 2.87 & 0.6 & 1.14 \\
\hline C-310672 & GLOC-9_17-19 & 18 & 45 & 1.98 & 0.1 & 1.88 & 3.14 & 0.65 & 1.24 \\
\hline C-310647 & GLOC-9_19-21 & 20 & 50 & 3.36 & 0.06 & 3.3 & 3.27 & 0.55 & 1.31 \\
\hline C-310639 & GLOC-9_21-23 & 22 & 55 & 2.04 & 0.22 & 1.82 & 3.46 & 0.98 & 1.43 \\
\hline C-310628 & GLOC-9_23-25 & 24 & 60 & 1.53 & 0.1 & 1.43 & 3.05 & 0.58 & 1.28 \\
\hline C-310629 & GLOC-9_25-27 & 26 & 65 & 1.16 & 0.08 & 1.08 & 2.46 & 0.4 & 1.16 \\
\hline C-310645 & GLOC-9_27-29 & 28 & 70 & 0.68 & $<0.003$ & 0.68 & 3.17 & 0.17 & 1.21 \\
\hline C-310668 & GLOC-9_29-31 & 30 & 75 & 1.14 & 0.02 & 1.12 & 3.02 & 0.25 & 1.24 \\
\hline C-310653 & GLOC-9_31-33 & 32 & 80 & 1.19 & $<0.003$ & 1.19 & 3.19 & 0.22 & 1.24 \\
\hline C-310644 & GLOC- $9 \quad 33-35$ & 34 & 85 & 1.03 & 0.05 & 0.98 & 2.73 & 0.32 & 1.18 \\
\hline C-310649 & GLOC-9_35-37 & 36 & 90 & 0.74 & 0.01 & 0.73 & 3.21 & 0.17 & 1.23 \\
\hline C-310632 & GLOC-9_37-39 & 38 & 95 & 0.41 & $<0.003$ & 0.41 & 3.26 & 0.16 & 1.29 \\
\hline C-310669 & GLOC-9_39-41 & 40 & 100 & 0.43 & $<0.003$ & 0.43 & 3.45 & 0.16 & 1.32 \\
\hline C-310660 & GLOC-9_41-43 & 42 & 105 & 0.4 & 0.02 & 0.38 & 3.3 & 0.16 & 1.37 \\
\hline C-310640 & GLOC-9_43-45 & 44 & 110 & 0.41 & 0.02 & 0.39 & 3.58 & 0.18 & 1.52 \\
\hline C-310636 & GLOC-9_45-47 & 46 & 115 & 0.58 & 0.05 & 0.53 & 3.67 & 0.18 & 1.65 \\
\hline C-310659 & GLOC-9_47-49 & 48 & 120 & 0.42 & 0.04 & 0.38 & 3.64 & 0.18 & 1.65 \\
\hline C-310656 & GLOC-9_49-51 & 50 & 125 & 0.39 & 0.03 & 0.36 & 3.72 & 0.19 & 1.65 \\
\hline C-310630 & GLOC-9_51-53 & 54 & 135 & 0.37 & 0.02 & 0.35 & 3.89 & 0.18 & 1.71 \\
\hline C-310654 & GLOC-9_53-55 & 56 & 140 & 0.34 & 0.02 & 0.32 & 3.7 & 0.17 & 1.6 \\
\hline C-310651 & GLOC-9_55-57 & 58 & 145 & 0.34 & 0.01 & 0.33 & 3.79 & 0.18 & 1.61 \\
\hline C-310641 & GLOC-9_57-59 & 62 & 155 & 0.33 & 0.01 & 0.32 & 3.84 & 0.19 & 1.63 \\
\hline C-310658 & GLOC-9_59-61 & 64 & 160 & 0.32 & 0.01 & 0.31 & 3.8 & 0.18 & 1.59 \\
\hline C-310662 & GLOC-9_61-63 & 66 & 165 & 0.31 & 0.01 & 0.3 & 3.81 & 0.19 & 1.63 \\
\hline C-310643 & GLOC-9_63-65 & 68 & 170 & 0.29 & 0.01 & 0.28 & 3.72 & 0.19 & 1.61 \\
\hline C-310675 & GLOC-9_65-67 & 70 & 175 & 0.29 & 0.01 & 0.28 & 3.76 & 0.19 & 1.58 \\
\hline C-310631 & GLOC-9_67-69 & 72 & 180 & 0.28 & $<0.003$ & 0.28 & 3.79 & 0.19 & 1.57 \\
\hline C-310652 & GLOC-9_69-71 & 74 & 185 & 0.28 & $<0.003$ & 0.28 & 3.85 & 0.2 & 1.58 \\
\hline C-310633 & GLOC-9-71-73 & 78 & 195 & 0.25 & 0.01 & 0.24 & 3.94 & 0.21 & 1.61 \\
\hline C-310637 & GLOC-9_73-75 & 80 & 200 & 0.25 & $<0.003$ & 0.25 & 3.87 & 0.2 & 1.58 \\
\hline C-310638 & GLOC-9_75-77 & 82 & 205 & 0.24 & $<0.003$ & 0.24 & 3.94 & 0.21 & 1.58 \\
\hline C-310666 & GLOC-9_77-79 & 84 & 210 & 0.24 & 0.01 & 0.23 & 3.89 & 0.21 & 1.57 \\
\hline C-310635 & GLOC-9_79-81 & 86 & 215 & 0.23 & $<0.003$ & 0.23 & 3.88 & 0.21 & 1.56 \\
\hline C-310674 & GLOC-9_81-83 & 88 & 220 & 0.23 & $<0.003$ & 0.23 & 3.74 & 0.21 & 1.52 \\
\hline C-310667 & GLOC-9_83-85 & 90 & 225 & 0.21 & $<0.003$ & 0.21 & 3.77 & 0.21 & 1.54 \\
\hline C-310657 & GLOC-9_85-87 & 92 & 230 & 0.22 & 0.01 & 0.21 & 3.72 & 0.21 & 1.54 \\
\hline C-310664 & GLOC-9_87-89 & 94 & 235 & 0.21 & $<0.003$ & 0.21 & 3.75 & 0.21 & 1.53 \\
\hline
\end{tabular}


Table 1-3. Core sediment background sample analyses for GLOC-9, Elk River arm of Grand Lake O' the Cherokees. Analyses by ICP-AES/MS after four-acid digestion, except for forms of carbon.-Continued

[ICP-AES/MS, inductively coupled plasma-atomic emission spectroscopy/mass spectroscopy; $\mathrm{cm}$, centimeter; \%, percent; ppm, parts per million]

\begin{tabular}{|c|c|c|c|c|c|c|c|c|c|}
\hline Lab no. & Field no. & $\mathrm{K} \%$ & $\mathrm{Mg} \%$ & $\mathrm{Na} \%$ & $\mathrm{~S} \%$ & $\mathrm{Ti} \%$ & As ppm & Ba ppm & Bi ppm \\
\hline C-310665 & GLOC-9_1-3 & 0.95 & 0.19 & 0.21 & 0.05 & 0.16 & 3 & 284 & 0.13 \\
\hline C-310655 & GLOC-9_3-5 & 1.03 & 0.2 & 0.23 & 0.04 & 0.18 & 3 & 311 & 0.14 \\
\hline C-310627 & GLOC-9_5-7 & 0.98 & 0.18 & 0.22 & 0.04 & 0.17 & 3 & 295 & 0.14 \\
\hline C-310670 & GLOC-9_7-9 & 0.94 & 0.17 & 0.21 & 0.04 & 0.16 & 3 & 283 & 0.13 \\
\hline C-310671 & GLOC-9_9-11 & 0.89 & 0.15 & 0.21 & 0.03 & 0.16 & 3 & 270 & 0.11 \\
\hline C-310661 & GLOC-9 $11-13$ & 0.98 & 0.16 & 0.23 & 0.03 & 0.17 & 3 & 292 & 0.11 \\
\hline C-310650 & GLOC-9_13-15 & 0.95 & 0.17 & 0.22 & 0.02 & 0.17 & 3 & 288 & 0.13 \\
\hline C-310642 & GLOC-9_15-17 & 0.95 & 0.18 & 0.23 & 0.03 & 0.18 & 3 & 301 & 0.12 \\
\hline C-310672 & GLOC-9_17-19 & 1.08 & 0.2 & 0.24 & 0.04 & 0.19 & 3 & 329 & 0.18 \\
\hline C-310647 & GLOC-9_19-21 & 1.04 & 0.21 & 0.23 & 0.05 & 0.19 & 4 & 343 & 0.15 \\
\hline C-310639 & GLOC-9_21-23 & 1.11 & 0.22 & 0.23 & 0.04 & 0.2 & 5 & 352 & 0.17 \\
\hline C-310628 & GLOC-9_23-25 & 0.98 & 0.18 & 0.24 & 0.03 & 0.19 & 4 & 333 & 0.14 \\
\hline C-310629 & GLOC-9_25-27 & 0.83 & 0.15 & 0.18 & 0.02 & 0.16 & 4 & 275 & 0.12 \\
\hline C-310645 & GLOC-9_27-29 & 1.13 & 0.19 & 0.25 & 0.01 & 0.18 & 4 & 360 & 0.15 \\
\hline C-310668 & GLOC-9_29-31 & 1.04 & 0.18 & 0.23 & 0.02 & 0.18 & 4 & 337 & 0.14 \\
\hline C-310653 & GLOC-9_31-33 & 1.1 & 0.2 & 0.24 & 0.02 & 0.19 & 4 & 363 & 0.16 \\
\hline C-310644 & GLOC-9_33-35 & 0.95 & 0.16 & 0.22 & 0.02 & 0.17 & 4 & 302 & 0.12 \\
\hline C-310649 & GLOC-9_35-37 & 1.11 & 0.19 & 0.25 & 0.01 & 0.19 & 4 & 363 & 0.15 \\
\hline C-310632 & GLOC-9_37-39 & 1.1 & 0.2 & 0.24 & 0.01 & 0.18 & 4 & 356 & 0.15 \\
\hline C-310669 & GLOC-9_39-41 & 1.17 & 0.2 & 0.24 & 0.01 & 0.19 & 4 & 367 & 0.15 \\
\hline C-310660 & GLOC-9_41-43 & 1.09 & 0.2 & 0.22 & 0.01 & 0.18 & 4 & 352 & 0.15 \\
\hline C-310640 & GLOC-9_43-45 & 1.15 & 0.22 & 0.23 & 0.01 & 0.19 & 5 & 349 & 0.15 \\
\hline C-310636 & GLOC-9_45-47 & 1.16 & 0.22 & 0.23 & 0.01 & 0.19 & 5 & 347 & 0.16 \\
\hline C-310659 & GLOC-9_47-49 & 1.12 & 0.22 & 0.22 & 0.01 & 0.19 & 5 & 342 & 0.16 \\
\hline C-310656 & GLOC-9_49-51 & 1.14 & 0.23 & 0.22 & 0.01 & 0.19 & 5 & 339 & 0.15 \\
\hline C-310630 & GLOC-9_51-53 & 1.18 & 0.24 & 0.22 & 0.01 & 0.2 & 5 & 346 & 0.16 \\
\hline C-310654 & GLOC-9_53-55 & 1.14 & 0.23 & 0.22 & 0.01 & 0.19 & 4 & 339 & 0.17 \\
\hline C-310651 & GLOC-9_55-57 & 1.16 & 0.23 & 0.23 & 0.01 & 0.19 & 4 & 341 & 0.15 \\
\hline C-310641 & GLOC-9_57-59 & 1.19 & 0.24 & 0.23 & 0.01 & 0.2 & 5 & 347 & 0.16 \\
\hline C-310658 & GLOC-9_59-61 & 1.17 & 0.24 & 0.23 & 0.01 & 0.19 & 5 & 353 & 0.17 \\
\hline C-310662 & GLOC-9_61-63 & 1.16 & 0.24 & 0.23 & $<0.01$ & 0.19 & 5 & 362 & 0.17 \\
\hline C-310643 & GLOC-9_63-65 & 1.16 & 0.23 & 0.23 & $<0.01$ & 0.19 & 5 & 351 & 0.16 \\
\hline C-310675 & GLOC-9_65-67 & 1.18 & 0.24 & 0.23 & $<0.01$ & 0.19 & 4 & 356 & 0.17 \\
\hline C-310631 & GLOC-9_67-69 & 1.18 & 0.24 & 0.24 & $<0.01$ & 0.2 & 5 & 360 & 0.16 \\
\hline C-310652 & GLOC-9_69-71 & 1.21 & 0.24 & 0.25 & $<0.01$ & 0.2 & 4 & 373 & 0.16 \\
\hline C-310633 & GLOC-9-71-73 & 1.25 & 0.25 & 0.26 & 0.01 & 0.2 & 5 & 393 & 0.18 \\
\hline C-310637 & GLOC-9_73-75 & 1.23 & 0.25 & 0.26 & $<0.01$ & 0.2 & 5 & 387 & 0.2 \\
\hline C-310638 & GLOC-9_75-77 & 1.27 & 0.25 & 0.27 & 0.01 & 0.21 & 5 & 392 & 0.16 \\
\hline C-310666 & GLOC-9-77-79 & 1.25 & 0.25 & 0.27 & 0.01 & 0.2 & 5 & 408 & 0.16 \\
\hline C-310635 & GLOC-9_79-81 & 1.22 & 0.25 & 0.27 & $<0.01$ & 0.19 & 5 & 391 & 0.16 \\
\hline C-310674 & GLOC-9_81-83 & 1.21 & 0.24 & 0.27 & $<0.01$ & 0.21 & 4 & 389 & 0.2 \\
\hline C-310667 & GLOC-9_83-85 & 1.22 & 0.24 & 0.27 & $<0.01$ & 0.2 & 5 & 390 & 0.17 \\
\hline C-310657 & GLOC-9_85-87 & 1.19 & 0.24 & 0.26 & $<0.01$ & 0.2 & 4 & 383 & 0.15 \\
\hline C-310664 & GLOC-9_87-89 & 1.2 & 0.24 & 0.27 & $<0.01$ & 0.21 & 4 & 385 & 0.16 \\
\hline
\end{tabular}


Table 1-3. Core sediment background sample analyses for GLOC-9, Elk River arm of Grand Lake O' the Cherokees. Analyses by ICP-AES/MS after four-acid digestion, except for forms of carbon.-Continued

[ICP-AES/MS, inductively coupled plasma-atomic emission spectroscopy/mass spectroscopy; cm, centimeter; \%, percent; ppm, parts per million]

\begin{tabular}{|c|c|c|c|c|c|c|c|c|c|}
\hline Lab no. & Field no. & Cd ppm & Co ppm & Crppm & Cu ppm & Ga ppm & In ppm & Li ppm & Mn ppm \\
\hline C-310665 & GLOC-9_1-3 & 0.4 & 8 & 53 & 12.2 & 6 & 0.02 & 17 & 317 \\
\hline C-310655 & GLOC-9_3-5 & 0.5 & 7.6 & 28 & 10.9 & 6 & 0.02 & 18 & 301 \\
\hline C-310627 & GLOC-9_5-7 & 0.4 & 7.4 & 38 & 11.3 & 6 & 0.02 & 17 & 302 \\
\hline C-310670 & GLOC-9_7-9 & 0.4 & 7.1 & 41 & 11.1 & 6 & 0.02 & 16 & 284 \\
\hline C-310671 & GLOC-9_9-11 & 0.4 & 6.3 & 33 & 9.9 & 5.1 & $<0.02$ & 16 & 287 \\
\hline C-310661 & GLOC-9-11-13 & 0.3 & 6.5 & 29 & 10.5 & 5.3 & $<0.02$ & 17 & 314 \\
\hline C-310650 & GLOC-9-13-15 & 0.3 & 7.6 & 33 & 10.6 & 6 & 0.02 & 17 & 354 \\
\hline C-310642 & GLOC-9-15-17 & 0.4 & 6.9 & 25 & 10.7 & 5.6 & $<0.02$ & 18 & 355 \\
\hline C-310672 & GLOC-9-17-19 & 0.4 & 7.8 & 27 & 12 & 6.9 & 0.03 & 20 & 428 \\
\hline C-310647 & GLOC-9_19-21 & 0.4 & 7.2 & 45 & 12.3 & 6.9 & 0.03 & 20 & 474 \\
\hline C-310639 & GLOC-9_21-23 & 0.5 & 9 & 36 & 13.7 & 7.9 & 0.03 & 21 & 802 \\
\hline C-310628 & GLOC-9_23-25 & 0.4 & 7.6 & 33 & 11.7 & 6.3 & 0.02 & 19 & 580 \\
\hline C-310629 & GLOC-9_25-27 & 0.4 & 7.2 & 24 & 10.1 & 5.4 & 0.02 & 15 & 683 \\
\hline C-310645 & GLOC-9_27-29 & 0.4 & 8 & 52 & 12.3 & 7.4 & 0.03 & 19 & 378 \\
\hline C-310668 & GLOC-9_29-31 & 0.4 & 9.9 & 34 & 12 & 6.8 & 0.03 & 18 & 388 \\
\hline C-310653 & GLOC-9_31-33 & 0.4 & 10 & 30 & 13 & 7.1 & 0.03 & 19 & 414 \\
\hline C-310644 & GLOC-9_33-35 & 0.4 & 9.3 & 30 & 11 & 6 & 0.02 & 18 & 599 \\
\hline C-310649 & GLOC-9_35-37 & 0.4 & 8 & 38 & 12.2 & 7.3 & 0.03 & 19 & 369 \\
\hline C-310632 & GLOC-9_37-39 & 0.3 & 8.4 & 36 & 11.3 & 7.4 & 0.03 & 19 & 360 \\
\hline C-310669 & GLOC-9_39-41 & 0.3 & 8.2 & 35 & 11.4 & 7.4 & 0.03 & 20 & 385 \\
\hline C-310660 & GLOC-9_41-43 & 0.2 & 9.8 & 65 & 11.9 & 8 & 0.03 & 20 & 570 \\
\hline C-310640 & GLOC-9_43-45 & 0.2 & 8.4 & 35 & 11.3 & 8 & 0.03 & 21 & 695 \\
\hline C-310636 & GLOC-9_45-47 & 0.2 & 9.3 & 37 & 11.9 & 8.1 & 0.03 & 21 & 1,110 \\
\hline C-310659 & GLOC-9_47-49 & 0.2 & 9.8 & 32 & 11.6 & 8 & 0.03 & 21 & 1,060 \\
\hline C-310656 & GLOC-9_49-51 & 0.3 & 9.9 & 37 & 12.3 & 7.9 & 0.03 & 21 & 980 \\
\hline C-310630 & GLOC-9_51-53 & 0.2 & 11 & 35 & 12.4 & 8.7 & 0.03 & 22 & 798 \\
\hline C-310654 & GLOC-9_53-55 & 0.2 & 10.5 & 37 & 12.2 & 8.6 & 0.03 & 21 & 754 \\
\hline C-310651 & GLOC-9_55-57 & 0.3 & 9.4 & 32 & 12.8 & 8.1 & 0.03 & 21 & 745 \\
\hline C-310641 & GLOC-9_57-59 & 0.2 & 8.9 & 36 & 12.8 & 8.5 & 0.03 & 22 & 704 \\
\hline C-310658 & GLOC-9-59-61 & 0.3 & 8.7 & 44 & 12.4 & 8.9 & 0.03 & 22 & 727 \\
\hline C-310662 & GLOC-9_61-63 & 0.3 & 9.3 & 43 & 12.8 & 9.1 & 0.03 & 21 & 738 \\
\hline C-310643 & GLOC-9_63-65 & 0.2 & 9 & 35 & 12.6 & 7.9 & 0.03 & 21 & 799 \\
\hline C-310675 & GLOC-9_65-67 & 0.3 & 9.6 & 32 & 12.5 & 8.4 & 0.03 & 21 & 798 \\
\hline C-310631 & GLOC-9_67-69 & 0.3 & 9.7 & 40 & 12.9 & 8.4 & 0.03 & 22 & 897 \\
\hline C-310652 & GLOC-9_69-71 & 0.4 & 9 & 38 & 12.6 & 8.5 & 0.03 & 21 & 869 \\
\hline C-310633 & GLOC-9-71-73 & 0.3 & 10.2 & 68 & 14.1 & 9.1 & 0.04 & 22 & 892 \\
\hline C-310637 & GLOC-9_73-75 & 0.4 & 9.7 & 36 & 13.6 & 8.9 & 0.03 & 22 & 875 \\
\hline C-310638 & GLOC-9_75-77 & 0.4 & 9 & 39 & 13.7 & 8.6 & 0.03 & 22 & 818 \\
\hline C-310666 & GLOC-9-77-79 & 0.3 & 10.1 & 36 & 13.9 & 8.9 & 0.03 & 22 & 911 \\
\hline C-310635 & GLOC-9_79-81 & 0.3 & 9.2 & 49 & 13.2 & 8.6 & 0.03 & 22 & 880 \\
\hline C-310674 & GLOC-9_81-83 & 0.3 & 9 & 34 & 17.6 & 8.5 & 0.03 & 21 & 824 \\
\hline C-310667 & GLOC-9-83-85 & 0.2 & 9.8 & 68 & 13.3 & 8.6 & 0.03 & 21 & 857 \\
\hline C-310657 & GLOC-9_85-87 & 0.2 & 8.1 & 46 & 12.4 & 7.4 & 0.03 & 21 & 825 \\
\hline C-310664 & GLOC-9_87-89 & 0.2 & 9.4 & 35 & 12.8 & 8.4 & 0.03 & 21 & 809 \\
\hline
\end{tabular}


Table 1-3. Core sediment background sample analyses for GLOC-9, Elk River arm of Grand Lake O' the Cherokees. Analyses by ICP-AES/MS after four-acid digestion, except for forms of carbon.-Continued

[ICP-AES/MS, inductively coupled plasma-atomic emission spectroscopy/mass spectroscopy; cm, centimeter; \%, percent; ppm, parts per million]

\begin{tabular}{|c|c|c|c|c|c|c|c|c|}
\hline Lab no. & Field no. & Ni ppm & P ppm & $\mathrm{Pb} \mathrm{ppm}$ & $\mathrm{Rb} p p m$ & Sr ppm & V ppm & Zn ppm \\
\hline C-310665 & GLOC-9_1-3 & 30.8 & 340 & 16 & 46.8 & 39.2 & 41 & 55 \\
\hline C-310655 & GLOC-9_3-5 & 16.2 & 360 & 17.7 & 49.3 & 40.2 & 42 & 57 \\
\hline C-310627 & GLOC-9_5-7 & 19.7 & 370 & 16.1 & 51.1 & 38.4 & 43 & 55 \\
\hline C-310670 & GLOC-9_7-9 & 20.4 & 320 & 16.5 & 46.9 & 36 & 40 & 53 \\
\hline C-310671 & GLOC-9_9-11 & 16.6 & 290 & 15.1 & 43.4 & 35 & 35 & 52 \\
\hline C-310661 & GLOC-9_11-13 & 15.3 & 320 & 15.2 & 46.6 & 37.8 & 38 & 51 \\
\hline C-310650 & GLOC-9_13-15 & 17.5 & 320 & 17.4 & 47.4 & 35.8 & 40 & 53 \\
\hline C-310642 & GLOC-9_15-17 & 15.8 & 330 & 17 & 48.7 & 37.7 & 41 & 57 \\
\hline C-310672 & GLOC-9-17-19 & 16 & 410 & 19.1 & 54.9 & 40.4 & 46 & 66 \\
\hline C-310647 & GLOC-9_19-21 & 18.6 & 460 & 18.8 & 59.3 & 39.6 & 50 & 71 \\
\hline C-310639 & GLOC-9_21-23 & 19.5 & 510 & 22.1 & 59.3 & 42.2 & 54 & 74 \\
\hline C-310628 & GLOC-9_23-25 & 18.1 & 430 & 18.2 & 53.5 & 39.4 & 46 & 61 \\
\hline C-310629 & GLOC-9_25-27 & 14.1 & 350 & 16.2 & 42.6 & 32.3 & 37 & 52 \\
\hline C-310645 & GLOC-9_27-29 & 25.9 & 310 & 15.8 & 61.2 & 40.3 & 51 & 44 \\
\hline C-310668 & GLOC-9 29-31 & 19.4 & 360 & 19.3 & 54.8 & 38.2 & 47 & 60 \\
\hline C-310653 & GLOC-9_31-33 & 20.3 & 360 & 19.9 & 59.5 & 40 & 49 & 55 \\
\hline C-310644 & GLOC-9_33-35 & 20.1 & 320 & 17.3 & 47.6 & 36.6 & 40 & 55 \\
\hline C-310649 & GLOC-9_35-37 & 21.4 & 320 & 16.1 & 60.1 & 40.5 & 52 & 45 \\
\hline C-310632 & GLOC-9_37-39 & 20.1 & 290 & 15.6 & 59.4 & 38.7 & 51 & 44 \\
\hline C-310669 & GLOC-9_39-41 & 19.2 & 270 & 15.5 & 60.8 & 40 & 54 & 45 \\
\hline C-310660 & GLOC-9_41-43 & 33.7 & 270 & 15.5 & 62 & 37.5 & 53 & 43 \\
\hline C-310640 & GLOC-9_43-45 & 20 & 270 & 15.2 & 63.4 & 38.1 & 56 & 48 \\
\hline C-310636 & GLOC-9_45-47 & 20.1 & 270 & 15.6 & 63.1 & 38.2 & 56 & 46 \\
\hline C-310659 & GLOC-9_47-49 & 20.1 & 250 & 15.4 & 64.7 & 36.6 & 58 & 50 \\
\hline C-310656 & GLOC-9_49-51 & 22.6 & 260 & 15.8 & 60.1 & 37.4 & 58 & 48 \\
\hline C-310630 & GLOC-9_51-53 & 21.7 & 260 & 16 & 65.4 & 38.9 & 60 & 49 \\
\hline C-310654 & GLOC-9_53-55 & 21.7 & 250 & 16.2 & 64 & 36.9 & 60 & 50 \\
\hline C-310651 & GLOC-9_55-57 & 19.7 & 250 & 15.9 & 62 & 38.1 & 57 & 49 \\
\hline C-310641 & GLOC-9_57-59 & 21.6 & 240 & 16.8 & 64 & 39.1 & 59 & 53 \\
\hline C-310658 & GLOC-9_59-61 & 23 & 220 & 16.2 & 66.1 & 38.6 & 60 & 52 \\
\hline C-310662 & GLOC-9_61-63 & 23.8 & 230 & 16.5 & 65.8 & 38.7 & 61 & 52 \\
\hline C-310643 & GLOC-9_63-65 & 24.2 & 210 & 14.8 & 64 & 38.6 & 60 & 51 \\
\hline C-310675 & GLOC-9_65-67 & 20.5 & 210 & 16 & 62.8 & 38.5 & 57 & 51 \\
\hline C-310631 & GLOC-9_67-69 & 21.8 & 230 & 15.8 & 62.5 & 40.9 & 59 & 51 \\
\hline C-310652 & GLOC-9_69-71 & 21.9 & 230 & 16.5 & 63.9 & 41.2 & 59 & 52 \\
\hline C-310633 & GLOC-9_71-73 & 35.5 & 240 & 16.3 & 67 & 43 & 62 & 53 \\
\hline C-310637 & GLOC-9_73-75 & 22.6 & 220 & 16.3 & 64.6 & 42.3 & 60 & 53 \\
\hline C-310638 & GLOC-9-75-77 & 23.8 & 220 & 16.5 & 65.2 & 43.7 & 60 & 52 \\
\hline C-310666 & GLOC-9_77-79 & 26.3 & 220 & 17.1 & 66.3 & 43.9 & 61 & 54 \\
\hline C-310635 & GLOC-9_79-81 & 23.8 & 210 & 16.5 & 63 & 43.4 & 58 & 52 \\
\hline C-310674 & GLOC-9_81-83 & 21.9 & 210 & 16.6 & 65.5 & 42.4 & 60 & 51 \\
\hline C-310667 & GLOC-9_83-85 & 36.8 & 220 & 16.8 & 62.6 & 43.3 & 60 & 50 \\
\hline C-310657 & GLOC-9_85-87 & 23.3 & 210 & 14 & 60.8 & 42.6 & 57 & 51 \\
\hline C-310664 & GLOC-9_87-89 & 20.6 & 210 & 15.8 & 62.5 & 43 & 58 & 50 \\
\hline
\end{tabular}


Table 1-4. Core sediment sample analyses for GLOC-2, Neosho River upstream from Grand Lake O' the Cherokees. Analyses by ICP-AES/MS after four-acid digestion, except for forms of carbon. (Click to see Excel file.) [ICP-AES/MS, inductively coupled plasma-atomic emission spectroscopy/mass spectroscopy; cm, centimeter; \%, percent; ppm, parts per million]

\begin{tabular}{|c|c|c|c|c|c|c|c|c|c|}
\hline Lab no. & Field no. & $\begin{array}{l}\text { Depth in } \\
\text { inches }\end{array}$ & $\begin{array}{l}\text { Depth } \\
\text { in cm }\end{array}$ & $\begin{array}{c}\text { Total } \\
\text { C \% }\end{array}$ & $\begin{array}{c}\text { Carbonate } \\
\text { C \% }\end{array}$ & $\begin{array}{c}\text { Organic } \\
\text { C } \%\end{array}$ & Al $\%$ & $\mathrm{Ca} \%$ & $\mathrm{Fe} \%$ \\
\hline C-312239 & GLOC-2_1-3 & 2 & 5 & 1.01 & 0.07 & 0.94 & 5.42 & 0.70 & 2.34 \\
\hline C-312296 & GLOC-2_3-5 & 4 & 10 & 1.01 & 0.03 & 0.98 & 5.28 & 0.59 & 2.20 \\
\hline C-312263 & GLOC-2_5-7 & 6 & 15 & 1.02 & 0.03 & 0.99 & 5.35 & 0.57 & 2.24 \\
\hline C-312276 & GLOC-2_7-9 & 8 & 20 & 1.03 & 0.03 & 1.00 & 5.24 & 0.55 & 2.25 \\
\hline C-312275 & GLOC-2_9-11 & 10 & 25 & 1.15 & 0.03 & 1.12 & 5.46 & 0.57 & 2.33 \\
\hline C-312258 & GLOC-2_11-13 & 12 & 30 & 0.98 & 0.02 & 0.96 & 5.04 & 0.48 & 2.06 \\
\hline C-312242 & GLOC-2_13-15 & 14 & 35 & 0.79 & 0.02 & 0.77 & 4.65 & 0.46 & 1.79 \\
\hline C-312302 & GLOC-2_15-17 & 16 & 40 & 0.96 & 0.03 & 0.93 & 4.96 & 0.53 & 2.17 \\
\hline C-312245 & GLOC-2_17-19 & 18 & 45 & 0.91 & 0.02 & 0.89 & 5.42 & 0.49 & 2.25 \\
\hline C-312254 & GLOC-2_19-21 & 20 & 50 & 1.08 & 0.02 & 1.06 & 5.87 & 0.54 & 2.54 \\
\hline C-312300 & GLOC-2_21-23 & 22 & 55 & 0.96 & 0.01 & 0.95 & 5.25 & 0.48 & 2.34 \\
\hline C-312247 & GLOC-2_23-25 & 24 & 60 & 0.89 & 0.02 & 0.87 & 5.36 & 0.45 & 2.36 \\
\hline C-312297 & GLOC-2_25-27 & 26 & 65 & 0.93 & 0.01 & 0.92 & 5.05 & 0.44 & 2.22 \\
\hline C-312283 & GLOC-2_27-29 & 28 & 70 & 0.91 & 0.02 & 0.89 & 5.44 & 0.50 & 2.37 \\
\hline C-312266 & GLOC-2_29-31 & 30 & 75 & 0.78 & 0.01 & 0.77 & 5.01 & 0.47 & 2.04 \\
\hline C-312309 & GLOC-2_31-33 & 32 & 80 & 0.98 & 0.02 & 0.96 & 5.06 & 0.49 & 2.18 \\
\hline C-312311 & GLOC-2_33-35 & 34 & 85 & 1.07 & 0.02 & 1.05 & 5.58 & 0.53 & 2.42 \\
\hline C-312307 & GLOC-2_35-37 & 36 & 90 & 1.08 & 0.01 & 1.07 & 5.36 & 0.51 & 2.46 \\
\hline C-312292 & GLOC-2_37-39 & 38 & 95 & 1.63 & 0.03 & 1.60 & 4.95 & 0.52 & 2.11 \\
\hline C-312298 & GLOC-2_39-41 & 40 & 100 & 1.1 & 0.08 & 1.02 & 4.88 & 0.62 & 2.31 \\
\hline C-312253 & GLOC-2_41-43 & 42 & 105 & 0.92 & 0.05 & 0.87 & 5.29 & 0.54 & 2.18 \\
\hline C-312271 & GLOC-2_43-45 & 44 & 110 & 1.25 & 0.01 & 1.24 & 5.94 & 0.65 & 2.67 \\
\hline C-312282 & GLOC-2_45-47 & 46 & 115 & 1.21 & 0.03 & 1.18 & 5.49 & 0.56 & 2.50 \\
\hline C-312310 & GLOC-2_47-49 & 48 & 120 & 1.11 & 0.03 & 1.08 & 5.73 & 0.55 & 2.37 \\
\hline C-312241 & GLOC-2_49-51 & 50 & 125 & 0.88 & 0.1 & 0.78 & 5.18 & 0.63 & 2.11 \\
\hline C-312308 & GLOC-2_51-53 & 52 & 130 & 0.83 & 0.07 & 0.76 & 4.94 & 0.58 & 2.01 \\
\hline C-312286 & GLOC-2_53-55 & 54 & 135 & 1.13 & 0.07 & 1.06 & 5.76 & 0.65 & 2.52 \\
\hline C-312248 & GLOC-2_55-57 & 56 & 140 & 1.04 & 0.13 & 0.91 & 5.9 & 0.54 & 2.51 \\
\hline C-312240 & GLOC-2_57-59 & 58 & 145 & 1.24 & 0.01 & 1.23 & 6.18 & 0.54 & 2.71 \\
\hline C-312280 & GLOC-2_59-61 & 60 & 150 & 0.74 & 0.07 & 0.67 & 4.56 & 0.54 & 1.88 \\
\hline C-312287 & GLOC-2_61-63 & 62 & 155 & 0.75 & 0.06 & 0.69 & 4.67 & 0.53 & 1.97 \\
\hline C-312261 & GLOC-2_63-65 & 64 & 160 & 0.98 & 0.06 & 0.92 & 5.29 & 0.60 & 2.39 \\
\hline C-312289 & GLOC-2_65-67 & 66 & 165 & 0.92 & 0.03 & 0.89 & 4.95 & 0.46 & 2.06 \\
\hline C-312285 & GLOC-2_67-69 & 68 & 170 & 1.05 & 0.04 & 1.01 & 5.34 & 0.53 & 2.24 \\
\hline C-312237 & GLOC-2_69-71 & 70 & 175 & 1.2 & 0.04 & 1.16 & 6.08 & 0.61 & 2.64 \\
\hline C-312304 & GLOC-2_71-73 & 72 & 180 & 1.15 & 0.05 & 1.10 & 5.67 & 0.62 & 2.63 \\
\hline C-312255 & GLOC-2_73-75 & 74 & 185 & 1.42 & 0.11 & 1.31 & 6.27 & 0.75 & 2.83 \\
\hline C-312281 & GLOC-2_75-77 & 76 & 190 & 1.37 & 0.08 & 1.29 & 6.06 & 0.71 & 2.68 \\
\hline C-312306 & GLOC-2_77-79 & 78 & 195 & 1.43 & 0.12 & 1.31 & 6.22 & 0.87 & 3.06 \\
\hline C-312264 & GLOC-2_79-81 & 80 & 200 & 1.19 & 0.13 & 1.06 & 5.59 & 0.79 & 2.47 \\
\hline C-312249 & GLOC-2_81-83 & 82 & 205 & 0.79 & 0.03 & 0.76 & 4.73 & 0.65 & 1.93 \\
\hline C-312265 & GLOC-2_83-85 & 84 & 210 & 1.1 & 0.13 & 0.97 & 5.46 & 0.81 & 2.29 \\
\hline C-312279 & GLOC-2_85-87 & 86 & 215 & 1.41 & 0.17 & 1.24 & 5.97 & 0.95 & 2.71 \\
\hline C-312301 & GLOC-2_87-89 & 88 & 220 & 1.16 & 0.2 & 0.96 & 5.69 & 1.1 & 2.38 \\
\hline C-312259 & GLOC-2_89-91 & 90 & 225 & 1.15 & 0.16 & 0.99 & 5.58 & 0.99 & 2.47 \\
\hline
\end{tabular}


Table 1-4. Core sediment sample analyses for GLOC-2, Neosho River upstream from Grand Lake O' the Cherokees. Analyses by ICP-AES/MS after four-acid digestion, except for forms of carbon.-Continued

[ICP-AES/MS, inductively coupled plasma-atomic emission spectroscopy/mass spectroscopy; cm, centimeter; \%, percent; ppm, parts per million]

\begin{tabular}{cccccccccc}
\hline Lab no. & Field no. & $\begin{array}{c}\text { Depth in } \\
\text { inches }\end{array}$ & $\begin{array}{c}\text { Depth } \\
\text { in cm }\end{array}$ & $\begin{array}{c}\text { Total } \\
\text { C \% }\end{array}$ & $\begin{array}{c}\text { Carbonate } \\
\text { C \% }\end{array}$ & $\begin{array}{c}\text { Organic } \\
\text { C \% }\end{array}$ & Al \% & Ca \% & Fe \% \\
\hline C-312290 & GLOC-2_91-93 & 92 & 230 & 1.62 & 0.16 & 1.46 & 7.02 & 1.02 & 3.20 \\
C-312238 & GLOC-2_93-95 & 94 & 235 & 1.29 & 0.08 & 1.21 & 6.23 & 0.74 & 2.89 \\
C-312303 & GLOC-2_95-97 & 96 & 240 & 1.25 & 0.08 & 1.17 & 5.68 & 0.67 & 2.50 \\
C-312251 & GLOC-2_97-99 & 98 & 245 & 1.24 & 0.09 & 1.15 & 6.04 & 0.70 & 2.66 \\
C-312236 & GLOC-2_99-101 & 100 & 250 & 1.39 & 0.14 & 1.25 & 6.7 & 0.76 & 3.15 \\
C-312293 & GLOC-2_101-103 & 102 & 255 & 1.47 & 0.19 & 1.28 & 6.48 & 0.93 & 3.01 \\
C-312277 & GLOC-2_103-105 & 104 & 260 & 1.45 & 0.11 & 1.34 & 6.28 & 0.75 & 2.69 \\
C-312262 & GLOC-2_105-107 & 106 & 265 & 1.18 & 0.07 & 1.11 & 5.89 & 0.61 & 2.50 \\
C-312246 & GLOC-2_107-109 & 108 & 270 & 1.28 & 0.1 & 1.18 & 6.04 & 0.68 & 2.61 \\
C-312291 & GLOC-2_109-111 & 110 & 275 & 1.16 & 0.11 & 1.05 & 5.32 & 0.67 & 2.32 \\
C-312256 & GLOC-2_111-113 & 112 & 280 & 0.84 & 0.12 & 0.72 & 4.55 & 0.61 & 1.93 \\
C-312299 & GLOC-2_113-115 & 114 & 285 & 1.09 & 0.2 & 0.89 & 5.08 & 0.93 & 2.21 \\
C-312295 & GLOC-2_115-117 & 116 & 290 & 1.44 & 0.28 & 1.16 & 6.09 & 1.01 & 3.09 \\
C-312274 & GLOC-2_117-119 & 118 & 295 & 1.4 & 0.05 & 1.35 & 6.35 & 0.59 & 2.79 \\
C-312250 & GLOC-2_119-121 & 120 & 300 & 1.44 & 0.03 & 1.41 & 6.75 & 0.53 & 3.02 \\
C-312272 & GLOC-2_121-123 & 122 & 305 & 1.79 & 0.1 & 1.69 & 6.81 & 0.60 & 3.57
\end{tabular}


Table 1-4. Core sediment sample analyses for GLOC-2, Neosho River upstream from Grand Lake O' the Cherokees. Analyses by ICP-AES/MS after four-acid digestion, except for forms of carbon.-Continued

[ICP-AES/MS, inductively coupled plasma-atomic emission spectroscopy/mass spectroscopy; cm, centimeter; \%, percent; ppm, parts per million]

\begin{tabular}{|c|c|c|c|c|c|c|c|c|}
\hline Lab no. & Field no. & $\mathrm{K} \%$ & $\mathrm{Mg} \%$ & $\mathrm{Na} \%$ & $\mathrm{~S} \%$ & $\mathrm{Ti} \%$ & As ppm & Ba ppm \\
\hline C-312239 & GLOC-2_1-3 & 1.58 & 0.47 & 0.63 & 0.03 & 0.24 & 7 & 488 \\
\hline C-312296 & GLOC-2 $3-5$ & 1.52 & 0.44 & 0.65 & 0.03 & 0.23 & 6 & 500 \\
\hline C-312263 & GLOC-2_5-7 & 1.52 & 0.43 & 0.64 & 0.03 & 0.22 & 6 & 508 \\
\hline C-312276 & GLOC-2_7-9 & 1.47 & 0.42 & 0.61 & 0.05 & 0.21 & 7 & 491 \\
\hline C-312275 & GLOC-2 9-11 & 1.50 & 0.44 & 0.60 & 0.06 & 0.22 & 7 & 512 \\
\hline C-312258 & GLOC-2_11-13 & 1.48 & 0.39 & 0.68 & 0.05 & 0.22 & 6 & 484 \\
\hline C-312242 & GLOC-2_13-15 & 1.47 & 0.35 & 0.72 & 0.06 & 0.22 & 5 & 467 \\
\hline C-312302 & GLOC-2_15-17 & 1.52 & 0.41 & 0.68 & 0.05 & 0.25 & 6 & 501 \\
\hline C-312245 & GLOC-2_17-19 & 1.56 & 0.43 & 0.67 & 0.04 & 0.25 & 6 & 504 \\
\hline C-312254 & GLOC-2_19-21 & 1.52 & 0.46 & 0.59 & 0.04 & 0.24 & 8 & 539 \\
\hline C-312300 & GLOC-2_21-23 & 1.57 & 0.44 & 0.64 & 0.03 & 0.25 & 8 & 530 \\
\hline C-312247 & GLOC-2_23-25 & 1.51 & 0.43 & 0.62 & 0.03 & 0.23 & 6 & 479 \\
\hline C-312297 & GLOC-2 25-27 & 1.38 & 0.4 & 0.58 & 0.03 & 0.24 & 6 & 475 \\
\hline C-312283 & GLOC-2_27-29 & 1.53 & 0.44 & 0.64 & 0.03 & 0.22 & 7 & 523 \\
\hline C-312266 & GLOC-2_29-31 & 1.44 & 0.37 & 0.67 & 0.03 & 0.21 & 6 & 499 \\
\hline C-312309 & GLOC-2_31-33 & 1.42 & 0.39 & 0.62 & 0.04 & 0.23 & 7 & 496 \\
\hline C-312311 & GLOC-2_33-35 & 1.51 & 0.44 & 0.61 & 0.04 & 0.27 & 6 & 527 \\
\hline C-312307 & GLOC-2_35-37 & 1.50 & 0.46 & 0.57 & 0.04 & 0.27 & 7 & 520 \\
\hline C-312292 & GLOC-2_37-39 & 1.34 & 0.39 & 0.56 & 0.09 & 0.21 & 8 & 443 \\
\hline C-312298 & GLOC-2_39-41 & 1.54 & 0.44 & 0.65 & 0.05 & 0.24 & 6 & 507 \\
\hline C-312253 & GLOC-2_41-43 & 1.49 & 0.42 & 0.64 & 0.06 & 0.22 & 7 & 502 \\
\hline C-312271 & GLOC-2_43-45 & 1.53 & 0.5 & 0.56 & 0.06 & 0.25 & 7 & 533 \\
\hline C-312282 & GLOC-2_45-47 & 1.49 & 0.46 & 0.57 & 0.08 & 0.26 & 10 & 502 \\
\hline C-312310 & GLOC-2_47-49 & 1.48 & 0.45 & 0.59 & 0.05 & 0.27 & 8 & 506 \\
\hline C-312241 & GLOC-2_49-51 & 1.60 & 0.42 & 0.72 & 0.04 & 0.23 & 4 & 507 \\
\hline C-312308 & GLOC-2_51-53 & 1.54 & 0.39 & 0.73 & 0.04 & 0.24 & 5 & 506 \\
\hline C-312286 & GLOC-2_53-55 & 1.52 & 0.47 & 0.59 & 0.05 & 0.23 & 7 & 515 \\
\hline C-312248 & GLOC-2_55-57 & 1.58 & 0.51 & 0.57 & 0.05 & 0.27 & 8 & 540 \\
\hline C-312240 & GLOC-2_57-59 & 1.57 & 0.56 & 0.52 & 0.04 & 0.26 & 6 & 546 \\
\hline C-312280 & GLOC-2_59-61 & 1.37 & 0.36 & 0.65 & 0.03 & 0.2 & 5 & 451 \\
\hline C-312287 & GLOC-2_61-63 & 1.36 & 0.39 & 0.59 & 0.03 & 0.2 & 5 & 454 \\
\hline C-312261 & GLOC-2_63-65 & 1.47 & 0.44 & 0.6 & 0.04 & 0.25 & 9 & 507 \\
\hline C-312289 & GLOC-2_65-67 & 1.37 & 0.4 & 0.58 & 0.04 & 0.2 & 8 & 469 \\
\hline C-312285 & GLOC-2_67-69 & 1.43 & 0.44 & 0.57 & 0.04 & 0.22 & 7 & 489 \\
\hline C-312237 & GLOC-2_69-71 & 1.57 & 0.51 & 0.55 & 0.05 & 0.24 & 9 & 523 \\
\hline C-312304 & GLOC-2_71-73 & 1.54 & 0.51 & 0.56 & 0.04 & 0.26 & 8 & 522 \\
\hline C-312255 & GLOC-2_73-75 & 1.52 & 0.55 & 0.49 & 0.05 & 0.26 & 9 & 524 \\
\hline C-312281 & GLOC-2_75-77 & 1.50 & 0.52 & 0.49 & 0.06 & 0.24 & 12 & 503 \\
\hline C-312306 & GLOC-2_77-79 & 1.61 & 0.61 & 0.48 & 0.06 & 0.28 & 11 & 552 \\
\hline C-312264 & GLOC-2_79-81 & 1.47 & 0.49 & 0.54 & 0.05 & 0.22 & 10 & 492 \\
\hline C-312249 & GLOC-2_81-83 & 1.48 & 0.38 & 0.68 & 0.03 & 0.22 & 6 & 453 \\
\hline C-312265 & GLOC-2_83-85 & 1.47 & 0.47 & 0.59 & 0.04 & 0.22 & 6 & 511 \\
\hline C-312279 & GLOC-2_85-87 & 1.51 & 0.54 & 0.5 & 0.07 & 0.24 & 11 & 534 \\
\hline C-312301 & GLOC-2_87-89 & 1.54 & 0.5 & 0.61 & 0.05 & 0.25 & 10 & 512 \\
\hline C-312259 & GLOC-2_89-91 & 1.56 & 0.54 & 0.6 & 0.05 & 0.23 & 9 & 553 \\
\hline
\end{tabular}


Table 1-4. Core sediment sample analyses for GLOC-2, Neosho River upstream from Grand Lake O' the Cherokees. Analyses by ICP-AES/MS after four-acid digestion, except for forms of carbon.-Continued

[ICP-AES/MS, inductively coupled plasma-atomic emission spectroscopy/mass spectroscopy; $\mathrm{cm}$, centimeter; \%, percent; ppm, parts per million]

\begin{tabular}{ccccccccc}
\hline Lab no. & Field no. & K \% & Mg \% & Na \% & S \% & Ti \% & As ppm & Ba ppm \\
\hline C-312290 & GLOC-2_91-93 & 1.68 & 0.76 & 0.41 & 0.05 & 0.26 & 9 & 532 \\
C-312238 & GLOC-2_93-95 & 1.53 & 0.53 & 0.5 & 0.06 & 0.27 & 15 & 571 \\
C-312303 & GLOC-2_95-97 & 1.44 & 0.47 & 0.54 & 0.05 & 0.26 & 7 & 503 \\
C-312251 & GLOC-2_97-99 & 1.53 & 0.52 & 0.52 & 0.05 & 0.26 & 8 & 506 \\
C-312236 & GLOC-2_99-101 & 1.70 & 0.62 & 0.51 & 0.05 & 0.25 & 9 & 549 \\
C-312293 & GLOC-2_101-103 & 1.61 & 0.59 & 0.51 & 0.04 & 0.25 & 9 & 549 \\
C-312277 & GLOC-2_103-105 & 1.51 & 0.54 & 0.48 & 0.05 & 0.24 & 12 & 516 \\
C-312262 & GLOC-2_105-107 & 1.54 & 0.52 & 0.57 & 0.05 & 0.25 & 7 & 515 \\
C-312246 & GLOC-2_107-109 & 1.53 & 0.53 & 0.51 & 0.06 & 0.26 & 7 & 498 \\
C-312291 & GLOC-2_109-111 & 1.37 & 0.45 & 0.48 & 0.06 & 0.21 & 8 & 481 \\
C-312256 & GLOC-2_111-113 & 1.26 & 0.36 & 0.55 & 0.05 & 0.2 & 7 & 417 \\
C-312299 & GLOC-2_113-115 & 1.40 & 0.44 & 0.59 & 0.04 & 0.23 & 7 & 472 \\
C-312295 & GLOC-2_115-117 & 1.54 & 0.56 & 0.5 & 0.06 & 0.27 & 12 & 542 \\
C-312274 & GLOC-2_117-119 & 1.51 & 0.56 & 0.49 & 0.05 & 0.24 & 8 & 526 \\
C-312250 & GLOC-2_119-121 & 1.58 & 0.54 & 0.49 & 0.05 & 0.28 & 10 & 523 \\
C-312272 & GLOC-2_121-123 & 1.54 & 0.58 & 0.41 & 0.06 & 0.29 & 10 & 556
\end{tabular}


Table 1-4. Core sediment sample analyses for GLOC-2, Neosho River upstream from Grand Lake O' the Cherokees. Analyses by ICP-AES/MS after four-acid digestion, except for forms of carbon.-Continued

[ICP-AES/MS, inductively coupled plasma-atomic emission spectroscopy/mass spectroscopy; cm, centimeter; \%, percent; ppm, parts per million]

\begin{tabular}{|c|c|c|c|c|c|c|c|c|}
\hline Lab no. & Field no. & Bi ppm & Cd ppm & Co ppm & Cr ppm & Cu ppm & Ga ppm & In ppm \\
\hline C-312239 & GLOC-2_1-3 & 0.21 & 0.4 & 10.6 & 50 & 14.8 & 12.9 & 0.04 \\
\hline C-312296 & GLOC-2_3-5 & 0.25 & 0.4 & 10.3 & 52 & 14.9 & 13.6 & 0.04 \\
\hline C-312263 & GLOC-2 5-7 & 0.23 & 0.5 & 10.9 & 51 & 15.2 & 13.4 & 0.04 \\
\hline C-312276 & GLOC-2_7-9 & 0.22 & 0.8 & 9.9 & 53 & 15.7 & 12.8 & 0.04 \\
\hline C-312275 & GLOC-2_9-11 & 0.24 & 0.6 & 11 & 53 & 16.5 & 13.6 & 0.04 \\
\hline C-312258 & GLOC-2 $11-13$ & 0.21 & 0.6 & 9.4 & 50 & 14.6 & 12.1 & 0.04 \\
\hline C-312242 & GLOC-2_13-15 & 0.17 & 0.5 & 8.7 & 40 & 12.9 & 10.5 & 0.04 \\
\hline C-312302 & GLOC-2_15-17 & 0.22 & 0.6 & 9.5 & 47 & 14.3 & 12.6 & 0.04 \\
\hline C-312245 & GLOC-2 $17-19$ & 0.21 & 0.6 & 10.2 & 50 & 15.6 & 12.3 & 0.04 \\
\hline C-312254 & GLOC-2_19-21 & 0.26 & 1.2 & 9.6 & 61 & 18.4 & 14.1 & 0.05 \\
\hline C-312300 & GLOC-2_21-23 & 0.26 & 0.7 & 11 & 49 & 16.9 & 13.8 & 0.05 \\
\hline C-312247 & GLOC-2_23-25 & 0.93 & 0.8 & 10.1 & 47 & 15.4 & 12.8 & 0.04 \\
\hline C-312297 & GLOC-2_25-27 & 0.25 & 0.8 & 10.2 & 51 & 14.8 & 12.8 & 0.04 \\
\hline C-312283 & GLOC-2 $27-29$ & 0.27 & 0.7 & 9.9 & 52 & 16.3 & 13.5 & 0.04 \\
\hline C-312266 & GLOC-2_29-31 & 0.23 & 0.7 & 8.5 & 49 & 14.5 & 11.8 & 0.04 \\
\hline C-312309 & GLOC-2_31-33 & 0.26 & 1.3 & 8.5 & 49 & 16.5 & 12.5 & 0.04 \\
\hline C-312311 & GLOC-2_33-35 & 0.27 & 1.7 & 9.4 & 60 & 17.7 & 14 & 0.05 \\
\hline C-312307 & GLOC-2_35-37 & 0.29 & 1.6 & 10.2 & 63 & 17.3 & 14.1 & 0.05 \\
\hline C-312292 & GLOC-2_37-39 & 0.26 & 1.2 & 10.6 & 49 & 16.3 & 12.8 & 0.04 \\
\hline C-312298 & GLOC-2 $39-41$ & 0.25 & 1.1 & 8.6 & 51 & 16 & 12.6 & 0.04 \\
\hline C-312253 & GLOC-2_41-43 & 0.23 & 0.8 & 10.2 & 52 & 17 & 13 & 0.04 \\
\hline C-312271 & GLOC-2_43-45 & 0.3 & 0.9 & 11.6 & 59 & 20.6 & 14.9 & 0.05 \\
\hline C-312282 & GLOC-2_45-47 & 0.32 & 2 & 11.7 & 58 & 19 & 14.8 & 0.05 \\
\hline C-312310 & GLOC-2_47-49 & 0.29 & 1 & 11 & 56 & 16.9 & 14.3 & 0.05 \\
\hline C-312241 & GLOC-2_49-51 & 0.2 & 0.4 & 9.4 & 43 & 14.2 & 11.5 & 0.04 \\
\hline C-312308 & GLOC-2_51-53 & 0.23 & 0.4 & 9.4 & 47 & 13.1 & 12.2 & 0.04 \\
\hline C-312286 & GLOC-2_53-55 & 0.25 & 0.6 & 10.2 & 57 & 17.1 & 13.8 & 0.05 \\
\hline C-312248 & GLOC-2_-55-57 & 0.25 & 1.5 & 11 & 55 & 18.1 & 13.9 & 0.05 \\
\hline C-312240 & GLOC-2_57-59 & 0.27 & 2.2 & 10.5 & 58 & 19.7 & 14.6 & 0.05 \\
\hline C-312280 & GLOC-2_59-61 & 0.2 & 0.7 & 9.4 & 43 & 12.7 & 11.4 & 0.04 \\
\hline C-312287 & GLOC-2_61-63 & 0.21 & 1 & 9 & 46 & 13.7 & 11.6 & 0.06 \\
\hline C-312261 & GLOC-2_63-65 & 0.26 & 1.3 & 10.2 & 53 & 15.5 & 13.3 & 0.05 \\
\hline C-312289 & GLOC-2_65-67 & 0.3 & 1.3 & 9.3 & 64 & 17.9 & 12.5 & 0.05 \\
\hline C-312285 & GLOC-2_67-69 & 0.24 & 1.4 & 9 & 56 & 16.3 & 12.7 & 0.06 \\
\hline C-312237 & GLOC-2_69-71 & 0.26 & 1.5 & 11.3 & 59 & 23 & 14.6 & 0.07 \\
\hline C-312304 & GLOC-2_71-73 & 0.27 & 1 & 11.2 & 57 & 18.7 & 14.9 & 0.06 \\
\hline C-312255 & GLOC-2_73-75 & 0.29 & 2.1 & 12.2 & 68 & 21 & 15.7 & 0.08 \\
\hline C-312281 & GLOC-2_75-77 & 0.29 & 3.1 & 11.9 & 65 & 21 & 15.2 & 0.09 \\
\hline C-312306 & GLOC-2_77-79 & 0.31 & 1.3 & 12.9 & 69 & 21.2 & 17.1 & 0.07 \\
\hline C-312264 & GLOC-2_79-81 & 0.25 & 1.2 & 9.7 & 56 & 17.6 & 14 & 0.06 \\
\hline C-312249 & GLOC-2_81-83 & 0.2 & 0.8 & 8 & 37 & 13.6 & 11.1 & 0.05 \\
\hline C-312265 & GLOC-2_-83-85 & 0.24 & 1.4 & 8.5 & 55 & 17.4 & 13.3 & 0.06 \\
\hline C-312279 & GLOC-2_85-87 & 0.31 & 4.1 & 10.5 & 61 & 23.3 & 15.2 & 0.17 \\
\hline C-312301 & GLOC-2_87-89 & 0.27 & 0.8 & 12.4 & 54 & 17.2 & 14.4 & 0.07 \\
\hline C-312259 & GLOC-2 89-91 & 0.25 & 0.6 & 10.1 & 55 & 17.8 & 13.7 & 0.05 \\
\hline
\end{tabular}


Table 1-4. Core sediment sample analyses for GLOC-2, Neosho River upstream from Grand Lake O' the Cherokees. Analyses by ICP-AES/MS after four-acid digestion, except for forms of carbon.-Continued

[ICP-AES/MS, inductively coupled plasma-atomic emission spectroscopy/mass spectroscopy; cm, centimeter; \%, percent; ppm, parts per million]

\begin{tabular}{ccccccccc}
\hline Lab no. & Field no. & Bi ppm & Cd ppm & Co ppm & Cr ppm & Cu ppm & Ga ppm & In ppm \\
\hline C-312290 & GLOC-2_91-93 & 0.35 & 0.8 & 13 & 65 & 26.7 & 18.2 & 0.07 \\
C-312238 & GLOC-2_93-95 & 0.28 & 4 & 10.2 & 59 & 21.6 & 14.8 & 0.1 \\
C-312303 & GLOC-2_95-97 & 0.31 & 2.9 & 9.5 & 58 & 19.7 & 14.5 & 0.08 \\
C-312251 & GLOC-2_97-99 & 0.31 & 2.6 & 11.5 & 62 & 20.4 & 15 & 0.09 \\
C-312236 & GLOC-2_99-101 & 0.3 & 1.6 & 14.6 & 63 & 26.5 & 15.9 & 0.11 \\
C-312293 & GLOC-2_101-103 & 0.31 & 1.2 & 11.6 & 65 & 21 & 17 & 0.12 \\
C-312277 & GLOC-2_103-105 & 0.33 & 2.7 & 11.5 & 69 & 24.2 & 16 & 0.22 \\
C-312262 & GLOC-2_105-107 & 0.3 & 1.1 & 11.3 & 63 & 18 & 14.7 & 0.07 \\
C-312246 & GLOC-2_107-109 & 0.25 & 1 & 10.8 & 60 & 19.1 & 14.3 & 0.08 \\
C-312291 & GLOC-2_109-111 & 0.24 & 1 & 10 & 58 & 16.2 & 13.4 & 0.06 \\
C-312256 & GLOC-2_111-113 & 0.21 & 1 & 9.7 & 47 & 14.2 & 11.2 & 0.09 \\
C-312299 & GLOC-2_113-115 & 0.26 & 1.2 & 9.1 & 52 & 16.8 & 12.3 & 0.13 \\
C-312295 & GLOC-2_115-117 & 0.34 & 2.4 & 12.4 & 63 & 21.5 & 15.9 & 0.13 \\
C-312274 & GLOC-2_117-119 & 0.3 & 1.4 & 13 & 66 & 22.5 & 16.1 & 0.08 \\
C-312250 & GLOC-2_119-121 & 0.31 & 3 & 12.1 & 66 & 25.7 & 16.7 & 0.1 \\
C-312272 & GLOC-2_121-123 & 0.39 & 3.7 & 11.5 & 74 & 29.6 & 17.1 & 0.19
\end{tabular}


Table 1-4. Core sediment sample analyses for GLOC-2, Neosho River upstream from Grand Lake O' the Cherokees. Analyses by ICP-AES/MS after four-acid digestion, except for forms of carbon.-Continued

[ICP-AES/MS, inductively coupled plasma-atomic emission spectroscopy/mass spectroscopy; cm, centimeter; \%, percent; ppm, parts per million]

\begin{tabular}{|c|c|c|c|c|c|c|c|c|}
\hline Lab no. & Field no. & Li ppm & Mn ppm & Ni ppm & P ppm & $\mathrm{Pb}$ ppm & Rb ppm & Sr ppm \\
\hline C-312239 & GLOC-2_1-3 & 31 & 521 & 22.7 & 630 & 19.6 & 94.1 & 113 \\
\hline C-312296 & GLOC-2_3-5 & 30 & 472 & 21.8 & 580 & 20.2 & 89 & 113 \\
\hline C-312263 & GLOC-2_5-7 & 30 & 470 & 21.3 & 610 & 20.8 & 87.2 & 113 \\
\hline C-312276 & GLOC-2_7-9 & 29 & 456 & 22.3 & 660 & 21.7 & 84.5 & 110 \\
\hline C-312275 & GLOC-2_9-11 & 31 & 475 & 22.4 & 660 & 22.9 & 89.8 & 112 \\
\hline C-312258 & GLOC-2_11-13 & 27 & 404 & 20.1 & 600 & 19.6 & 80.8 & 108 \\
\hline C-312242 & GLOC-2_13-15 & 25 & 320 & 17.6 & 470 & 18.7 & 78.6 & 101 \\
\hline C-312302 & GLOC-2_15-17 & 30 & 398 & 20.6 & 570 & 20.4 & 84.3 & 110 \\
\hline C-312245 & GLOC-2_17-19 & 31 & 434 & 22.5 & 560 & 22.2 & 87 & 108 \\
\hline C-312254 & GLOC-2_19-21 & 33 & 522 & 25.6 & 710 & 27.8 & 95.8 & 112 \\
\hline C-312300 & GLOC-2_21-23 & 32 & 446 & 22.7 & 580 & 24.2 & 94.6 & 109 \\
\hline C-312247 & GLOC-2_23-25 & 31 & 467 & 21.5 & 640 & 27.0 & 91.5 & 102 \\
\hline C-312297 & GLOC-2_25-27 & 29 & 422 & 22.2 & 600 & 24.6 & 82.3 & 100 \\
\hline C-312283 & GLOC-2_27-29 & 31 & 478 & 21.7 & 620 & 24.5 & 87.4 & 110 \\
\hline C-312266 & GLOC-2_29-31 & 27 & 414 & 19.5 & 510 & 24.9 & 79.4 & 107 \\
\hline C-312309 & GLOC-2_31-33 & 30 & 408 & 20.3 & 620 & 26.7 & 83.3 & 105 \\
\hline C-312311 & GLOC-2_33-35 & 33 & 450 & 24.1 & 680 & 28.8 & 91.4 & 111 \\
\hline C-312307 & GLOC-2_35-37 & 33 & 413 & 24.4 & 700 & 28.7 & 92.1 & 106 \\
\hline C-312292 & GLOC-2_37-39 & 29 & 402 & 22.3 & 690 & 26.4 & 82.8 & 101 \\
\hline C-312298 & GLOC-2_39-41 & 32 & 689 & 22.5 & 670 & 23.2 & 88.3 & 110 \\
\hline C-312253 & GLOC-2_41-43 & 30 & 506 & 22.2 & 570 & 22.8 & 85.2 & 109 \\
\hline C-312271 & GLOC-2_43-45 & 34 & 804 & 25.8 & 730 & 25.0 & 96.8 & 116 \\
\hline C-312282 & GLOC-2_45-47 & 34 & 526 & 26.6 & 670 & 30.2 & 92.9 & 109 \\
\hline C-312310 & GLOC-2_47-49 & 34 & 470 & 24.3 & 580 & 26.4 & 91.4 & 113 \\
\hline C-312241 & GLOC-2_49-51 & 29 & 740 & 19.8 & 470 & 19.5 & 82.1 & 114 \\
\hline C-312308 & GLOC-2_51-53 & 28 & 603 & 19.7 & 480 & 19.1 & 81.1 & 115 \\
\hline C-312286 & GLOC-2_53-55 & 33 & 721 & 24.2 & 590 & 23.7 & 92 & 119 \\
\hline C-312248 & GLOC-2_55-57 & 35 & 355 & 25.6 & 560 & 27.6 & 94.8 & 114 \\
\hline C-312240 & GLOC-2_57-59 & 38 & 335 & 28 & 630 & 29.1 & 101 & 114 \\
\hline C-312280 & GLOC-2_59-61 & 24 & 495 & 17.8 & 490 & 21.0 & 76.7 & 104 \\
\hline C-312287 & GLOC-2_61-63 & 26 & 480 & 19.7 & 500 & 23.1 & 75.8 & 102 \\
\hline C-312261 & GLOC-2_63-65 & 30 & 598 & 22.1 & 630 & 25.5 & 85.2 & 113 \\
\hline C-312289 & GLOC-2_65-67 & 28 & 404 & 24.2 & 520 & 24.6 & 81.9 & 103 \\
\hline C-312285 & GLOC-2_67-69 & 31 & 488 & 23.7 & 560 & 26.5 & 85 & 109 \\
\hline C-312237 & GLOC-2_69-71 & 36 & 635 & 27.6 & 650 & 27.9 & 98.2 & 115 \\
\hline C-312304 & GLOC-2_71-73 & 36 & 649 & 26.7 & 660 & 24.7 & 96 & 116 \\
\hline C-312255 & GLOC-2_73-75 & 37 & 787 & 30 & 680 & 29.7 & 99.9 & 120 \\
\hline C-312281 & GLOC-2_75-77 & 36 & 649 & 29.2 & 650 & 34.5 & 97.7 & 117 \\
\hline C-312306 & GLOC-2_77-79 & 40 & 715 & 31.2 & 690 & 25.7 & 109 & 126 \\
\hline C-312264 & GLOC-2_79-81 & 32 & 569 & 24.7 & 570 & 24.5 & 87.1 & 116 \\
\hline C-312249 & GLOC-2_81-83 & 26 & 577 & 17.8 & 440 & 20.9 & 81 & 109 \\
\hline C-312265 & GLOC-2_83-85 & 30 & 461 & 22.4 & 550 & 21.6 & 84.5 & 119 \\
\hline C-312279 & GLOC-2_85-87 & 36 & 597 & 27.2 & 740 & 39.1 & 94.6 & 126 \\
\hline C-312301 & GLOC-2_87-89 & 34 & 581 & 24.9 & 550 & 22.7 & 90.6 & 132 \\
\hline C-312259 & GLOC-2_89-91 & 31 & 560 & 22.2 & 590 & 21.2 & 90.8 & 129 \\
\hline
\end{tabular}


Table 1-4. Core sediment sample analyses for GLOC-2, Neosho River upstream from Grand Lake O' the Cherokees. Analyses by ICP-AES/MS after four-acid digestion, except for forms of carbon.-Continued

[ICP-AES/MS, inductively coupled plasma-atomic emission spectroscopy/mass spectroscopy; cm, centimeter; \%, percent; ppm, parts per million]

\begin{tabular}{clccccccc}
\hline Lab no. & Field no. & Li ppm & Mn ppm & Ni ppm & P ppm & Pb ppm & Rb ppm & Sr ppm \\
\hline C-312290 & GLOC-2_91-93 & 43 & 932 & 28.4 & 690 & 28.3 & 114 & 130 \\
C-312238 & GLOC-2_93-95 & 38 & 522 & 27.1 & 750 & 40.6 & 98.5 & 122 \\
C-312303 & GLOC-2_95-97 & 35 & 541 & 24.8 & 700 & 35.4 & 90.9 & 115 \\
C-312251 & GLOC-2_97-99 & 36 & 606 & 29.4 & 710 & 33.6 & 101 & 115 \\
C-312236 & GLOC-2_99-101 & 41 & 981 & 32.5 & 760 & 27.9 & 110 & 123 \\
C-312293 & GLOC-2_101-103 & 39 & 1,160 & 29.1 & 700 & 26.1 & 106 & 128 \\
C-312277 & GLOC-2_103-105 & 37 & 670 & 29.8 & 610 & 33.2 & 101 & 118 \\
C-312262 & GLOC-2_105-107 & 34 & 539 & 27 & 560 & 24.7 & 92.7 & 114 \\
C-312246 & GLOC-2_107-109 & 36 & 537 & 28.1 & 560 & 27.0 & 98.4 & 111 \\
C-312291 & GLOC-2_109-111 & 31 & 518 & 26.5 & 530 & 24.3 & 85.4 & 104 \\
C-312256 & GLOC-2_111-113 & 27 & 466 & 20.2 & 470 & 23.0 & 70.3 & 98.1 \\
C-312299 & GLOC-2_113-115 & 30 & 576 & 23.4 & 520 & 23.3 & 81.4 & 116 \\
C-312295 & GLOC-2_115-117 & 37 & 848 & 30 & 830 & 29.3 & 102 & 124 \\
C-312274 & GLOC-2_117-119 & 38 & 508 & 29.9 & 690 & 29.8 & 102 & 111 \\
C-312250 & GLOC-2_119-121 & 42 & 485 & 29.4 & 750 & 45.0 & 110 & 111 \\
C-312272 & GLOC-2_121-123 & 44 & 759 & 31.8 & 980 & 41.2 & 113 & 112
\end{tabular}


Table 1-4. Core sediment sample analyses for GLOC-2, Neosho River upstream from Grand Lake O' the Cherokees. Analyses by ICP-AES/MS after four-acid digestion, except for forms of carbon.-Continued

[ICP-AES/MS, inductively coupled plasma-atomic emission spectroscopy/mass spectroscopy; cm, centimeter; \%, percent; ppm, parts per million]

\begin{tabular}{|c|c|c|c|}
\hline Lab no. & Field no. & V ppm & Zn ppm \\
\hline C-312239 & GLOC-2_1-3 & 77 & 95 \\
\hline C-312296 & GLOC-2_3-5 & 78 & 113 \\
\hline C-312263 & GLOC-2 5-7 & 78 & 157 \\
\hline C-312276 & GLOC-2_7-9 & 80 & 197 \\
\hline C-312275 & GLOC-2_9-11 & 84 & 152 \\
\hline C-312258 & GLOC-2 $11-13$ & 72 & 167 \\
\hline C-312242 & GLOC-2_13-15 & 62 & 125 \\
\hline C-312302 & GLOC-2_15-17 & 76 & 161 \\
\hline C-312245 & GLOC-2 $17-19$ & 77 & 131 \\
\hline C-312254 & GLOC-2_-19-21 & 89 & 189 \\
\hline C-312300 & GLOC-2_21-23 & 80 & 132 \\
\hline C-312247 & GLOC-2_23-25 & 75 & 153 \\
\hline C-312297 & GLOC-2_25-27 & 78 & 180 \\
\hline C-312283 & GLOC-2 $27-29$ & 79 & 142 \\
\hline C-312266 & GLOC-2_29-31 & 72 & 113 \\
\hline C-312309 & GLOC-2_31-33 & 75 & 231 \\
\hline C-312311 & GLOC-2_33-35 & 88 & 289 \\
\hline C-312307 & GLOC-2_35-37 & 87 & 279 \\
\hline C-312292 & GLOC-2_37-39 & 76 & 283 \\
\hline C-312298 & GLOC-2 $39-41$ & 75 & 234 \\
\hline C-312253 & GLOC-2_41-43 & 78 & 185 \\
\hline C-312271 & GLOC-2_43-45 & 94 & 196 \\
\hline C-312282 & GLOC-2_45-47 & 87 & 475 \\
\hline C-312310 & GLOC-2_47-49 & 88 & 271 \\
\hline C-312241 & GLOC-2 $49-51$ & 70 & 113 \\
\hline C-312308 & GLOC-2_51-53 & 71 & 99 \\
\hline C-312286 & GLOC-2_53-55 & 88 & 141 \\
\hline C-312248 & GLOC-2_-55-57 & 86 & 372 \\
\hline C-312240 & GLOC-2_57-59 & 93 & 453 \\
\hline C-312280 & GLOC-2_59-61 & 67 & 162 \\
\hline C-312287 & GLOC-2_61-63 & 69 & 243 \\
\hline C-312261 & GLOC-2_63-65 & 81 & 315 \\
\hline C-312289 & GLOC-2_65-67 & 76 & 281 \\
\hline C-312285 & GLOC-2_67-69 & 81 & 327 \\
\hline C-312237 & GLOC-2_69-71 & 90 & 327 \\
\hline C-312304 & GLOC-2_71-73 & 87 & 236 \\
\hline C-312255 & GLOC-2_73-75 & 98 & 439 \\
\hline C-312281 & GLOC-2_75-77 & 95 & 563 \\
\hline C-312306 & GLOC-2_77-79 & 99 & 339 \\
\hline C-312264 & GLOC-2_79-81 & 86 & 288 \\
\hline C-312249 & GLOC-2_81-83 & 64 & 166 \\
\hline C-312265 & GLOC-2 $83-85$ & 85 & 393 \\
\hline C-312279 & GLOC-2_85-87 & 93 & 1,000 \\
\hline C-312301 & GLOC-2_87-89 & 85 & 194 \\
\hline C-312259 & GLOC-2_89-91 & 82 & 131 \\
\hline
\end{tabular}


Table 1-4. Core sediment sample analyses for GLOC-2, Neosho River upstream from Grand Lake O' the Cherokees. Analyses by ICP-AES/MS after four-acid digestion, except for forms of carbon.-Continued

[ICP-AES/MS, inductively coupled plasma-atomic emission spectroscopy/mass spectroscopy; cm, centimeter; \%, percent; ppm, parts per million]

\begin{tabular}{clrr}
\hline Lab no. & Field no. & V ppm & Zn ppm \\
\hline C-312290 & GLOC-2_91-93 & 112 & 170 \\
C-312238 & GLOC-2_93-95 & 94 & 649 \\
C-312303 & GLOC-2_95-97 & 88 & 536 \\
C-312251 & GLOC-2_97-99 & 91 & 464 \\
C-312236 & GLOC-2_99-101 & 100 & 364 \\
C-312293 & GLOC-2_101-103 & 102 & 212 \\
C-312277 & GLOC-2_-103-105 & 101 & 420 \\
C-312262 & GLOC-2_105-107 & 88 & 219 \\
C-312246 & GLOC-2_107-109 & 93 & 218 \\
C-312291 & GLOC-2_109-111 & 85 & 227 \\
C-312256 & GLOC-2_111-113 & 71 & 215 \\
C-312299 & GLOC-2_-113-115 & 75 & 265 \\
C-312295 & GLOC-2_115-117 & 96 & 563 \\
C-312274 & GLOC-2_117-119 & 101 & 244 \\
C-312250 & GLOC-2_119-121 & 101 & 438 \\
C-312272 & GLOC-2_111-123 & 112 & 634 \\
\hline
\end{tabular}


Table 1-5. Core sediment sample analyses for GLOC-3, Spring River upstream from Grand Lake O' the Cherokees. Analyses by ICP-AES/MS after four-acid digestion, except for forms of carbon. (Click to see Excel file.) [ICP-AES/MS, inductively coupled plasma-atomic emission spectroscopy/mass spectroscopy; cm, centimeter; \%, percent; ppm, parts per million; $\mathrm{n} / \mathrm{a}$, not applicable]

\begin{tabular}{|c|c|c|c|c|c|c|c|c|c|}
\hline Lab no. & Field no. & $\begin{array}{l}\text { Depth in } \\
\text { inches }\end{array}$ & $\begin{array}{l}\text { Depth } \\
\text { in } \mathrm{cm}\end{array}$ & $\begin{array}{l}\text { Total } \\
\text { C \% }\end{array}$ & $\begin{array}{c}\text { Carbonate } \\
\text { C \% }\end{array}$ & $\begin{array}{c}\text { Organic } \\
\text { C } \%\end{array}$ & $\mathrm{Al} \%$ & $\mathrm{Ca} \%$ & $\mathrm{Fe} \%$ \\
\hline C-312208 & GLOC-3_0-2 & 2 & 5 & 0.8 & 0.06 & 0.74 & 1.78 & 0.31 & 1.31 \\
\hline C-312225 & GLOC-3_2-4 & 4 & 10 & 2.09 & 0.11 & 1.98 & 4.12 & 0.68 & 2.04 \\
\hline C-312231 & GLOC-3_4-6 & 6 & 15 & 1.27 & 0.08 & 1.19 & 2.71 & 0.45 & 1.61 \\
\hline C-312228 & GLOC-3_6-8 & 8 & 20 & 1.07 & 0.06 & 1.01 & 2.40 & 0.36 & 1.49 \\
\hline C-312224 & GLOC-3_8-10 & 10 & 25 & 1.28 & 0.04 & 1.24 & 3.11 & 0.38 & 1.69 \\
\hline C-312198 & GLOC-3_10-12 & 12 & 30 & 1.55 & 0.02 & 1.53 & 3.48 & 0.37 & 1.91 \\
\hline C-312200 & GLOC-3_12-14 & 14 & 35 & 1.75 & 0.03 & 1.72 & 4.70 & 0.48 & 2.36 \\
\hline C-312192 & GLOC-3_14-16 & 16 & 40 & 1.49 & 0.08 & 1.41 & 3.62 & 0.53 & 1.82 \\
\hline C-312188 & GLOC-3_16-18 & 18 & 45 & 1.35 & 0.07 & 1.28 & 3.25 & 0.43 & 1.70 \\
\hline C-312191 & GLOC-3_18-20 & 20 & 50 & 1.48 & 0.04 & 1.44 & 3.83 & 0.40 & 1.95 \\
\hline C-312218 & GLOC-3_20-22 & 22 & 55 & $\mathrm{n} / \mathrm{a}$ & 0.05 & $\mathrm{n} / \mathrm{a}$ & 4.41 & 0.42 & 2.07 \\
\hline C-312210 & GLOC-3_22-24 & 24 & 60 & 1.52 & 0.01 & 1.51 & 4.71 & 0.36 & 2.13 \\
\hline C-312211 & GLOC-3_24-26 & 26 & 65 & 1.44 & 0.01 & 1.43 & 4.42 & 0.33 & 2.09 \\
\hline C-312204 & GLOC-3_26-28 & 28 & 70 & 1.47 & 0.01 & 1.46 & 4.51 & 0.33 & 2.08 \\
\hline C-312216 & GLOC-3_28-30 & 30 & 75 & 1.56 & 0.01 & 1.55 & 4.74 & 0.34 & 2.15 \\
\hline C-312197 & GLOC-3_30-32 & 32 & 80 & 1.58 & $<0.003$ & 1.58 & 4.83 & 0.35 & 2.23 \\
\hline C-312215 & GLOC-3_32-34 & 34 & 85 & 1.53 & 0.01 & 1.52 & 4.85 & 0.34 & 2.23 \\
\hline C-312212 & GLOC-3_34-36 & 36 & 90 & 1.48 & 0.01 & 1.47 & 4.90 & 0.34 & 2.28 \\
\hline C-312189 & GLOC-3_36-38 & 38 & 95 & 1.46 & 0.02 & 1.44 & 4.88 & 0.34 & 2.37 \\
\hline C-312226 & GLOC-3_38-40 & 40 & 100 & 1.47 & 0.02 & 1.45 & 5.08 & 0.35 & 2.50 \\
\hline C-312194 & GLOC-3_40-42 & 42 & 105 & 1.55 & 0.02 & 1.53 & 4.82 & 0.33 & 2.32 \\
\hline C-312230 & GLOC-3_42-44 & 44 & 110 & 1.45 & 0.04 & 1.41 & 5.27 & 0.36 & 2.49 \\
\hline C-312219 & GLOC-3_44-46 & 46 & 115 & 1.42 & 0.01 & 1.41 & 4.60 & 0.33 & 2.27 \\
\hline C-312223 & GLOC-3_46-48 & 48 & 120 & 1.39 & 0.01 & 1.38 & 4.68 & 0.33 & 2.21 \\
\hline C-312203 & GLOC-3_48-50 & 50 & 125 & 1.43 & 0.03 & 1.40 & 4.52 & 0.32 & 2.06 \\
\hline C-312195 & GLOC-3_50-52 & 52 & 130 & 1.31 & 0.01 & 1.30 & 4.16 & 0.28 & 1.72 \\
\hline C-312209 & GLOC-3_52-54 & 54 & 135 & 1.1 & 0.07 & 1.03 & 4.27 & 0.31 & 1.94 \\
\hline C-312205 & GLOC-3_54-56 & 56 & 140 & 0.92 & 0.02 & 0.90 & 4.25 & 0.27 & 1.66 \\
\hline C-312206 & GLOC-3_56-58 & 58 & 145 & 0.85 & $<0.003$ & 0.85 & 4.02 & 0.26 & 1.44 \\
\hline C-312214 & GLOC-3_58-60 & 60 & 150 & 0.65 & 0.01 & 0.64 & 3.69 & 0.22 & 1.35 \\
\hline C-312213 & GLOC-3_60-62 & 62 & 155 & 0.66 & 0.01 & 0.65 & 3.82 & 0.23 & 1.38 \\
\hline C-312196 & GLOC-3_62-64 & 64 & 160 & 0.66 & 0.01 & 0.65 & 3.83 & 0.23 & 1.35 \\
\hline C-312222 & GLOC-3_64-66 & 66 & 165 & 0.59 & 0.01 & 0.58 & 3.86 & 0.23 & 1.39 \\
\hline C-312221 & GLOC-3_66-68 & 68 & 170 & 0.54 & 0.02 & 0.52 & 3.93 & 0.22 & 1.43 \\
\hline C-312227 & GLOC-3_68-70 & 70 & 175 & 0.49 & 0.02 & 0.47 & 3.79 & 0.21 & 1.30 \\
\hline C-312202 & GLOC-3_70-72 & 72 & 180 & 0.49 & 0.01 & 0.48 & 3.85 & 0.21 & 1.25 \\
\hline C-312220 & GLOC-3_72-74 & 74 & 185 & 0.43 & $<0.003$ & 0.43 & 4.02 & 0.24 & 1.34 \\
\hline
\end{tabular}


Table 1-5. Core sediment sample analyses for GLOC-3, Spring River upstream from Grand Lake O' the Cherokees. Analyses by ICP-AES/MS after four-acid digestion, except for forms of carbon.-Continued

[ICP-AES/MS, inductively coupled plasma-atomic emission spectroscopy/mass spectroscopy; cm, centimeter; \%, percent; ppm, parts per million; $\mathrm{n} / \mathrm{a}$, not applicable]

\begin{tabular}{|c|c|c|c|c|c|c|c|c|c|}
\hline Lab no. & Field no. & $\mathrm{K} \%$ & $\mathrm{Mg} \%$ & $\mathrm{Na} \%$ & S $\%$ & $\mathrm{Ti} \%$ & As ppm & Ba ppm & Bi ppm \\
\hline C-312208 & GLOC-3_0-2 & 0.43 & 0.11 & 0.14 & 0.05 & 0.09 & 3 & 169 & 0.11 \\
\hline C-312225 & GLOC-3_2-4 & 1.02 & 0.24 & 0.32 & 0.1 & 0.21 & 6 & 386 & 0.23 \\
\hline C-312231 & GLOC-3 4-6 & 0.68 & 0.16 & 0.22 & 0.07 & 0.15 & 4 & 253 & 0.15 \\
\hline C-312228 & GLOC-3_6-8 & 0.63 & 0.15 & 0.23 & 0.05 & 0.13 & 3 & 236 & 0.14 \\
\hline C-312224 & GLOC-3_8-10 & 0.84 & 0.18 & 0.30 & 0.05 & 0.2 & 5 & 312 & 0.17 \\
\hline C-312198 & GLOC-3_10-12 & 0.85 & 0.19 & 0.28 & 0.05 & 0.19 & 5 & 324 & 0.19 \\
\hline C-312200 & GLOC-3_12-14 & 1.11 & 0.27 & 0.34 & 0.09 & 0.24 & 7 & 432 & 0.27 \\
\hline C-312192 & GLOC-3_14-16 & 0.94 & 0.21 & 0.33 & 0.11 & 0.21 & 6 & 343 & 0.20 \\
\hline C-312188 & GLOC-3_16-18 & 0.84 & 0.18 & 0.29 & 0.12 & 0.18 & 5 & 315 & 0.19 \\
\hline C-312191 & GLOC-3_18-20 & 0.95 & 0.22 & 0.31 & 0.1 & 0.21 & 5 & 357 & 0.24 \\
\hline C-312218 & GLOC-3_20-22 & 1.09 & 0.25 & 0.35 & 0.12 & 0.23 & 9 & 406 & 0.28 \\
\hline C-312210 & GLOC-3_22-24 & 1.15 & 0.26 & 0.36 & 0.09 & 0.24 & 8 & 429 & 0.36 \\
\hline C-312211 & GLOC-3_24-26 & 1.08 & 0.24 & 0.34 & 0.06 & 0.24 & 5 & 413 & 0.37 \\
\hline C-312204 & GLOC-3_26-28 & 1.11 & 0.25 & 0.35 & 0.06 & 0.24 & 5 & 438 & 0.33 \\
\hline C-312216 & GLOC-3_28-30 & 1.15 & 0.27 & 0.35 & 0.07 & 0.24 & 5 & 446 & 0.33 \\
\hline C-312197 & GLOC-3_30-32 & 1.16 & 0.27 & 0.37 & 0.05 & 0.25 & 6 & 468 & 0.38 \\
\hline C-312215 & GLOC-3_32-34 & 1.15 & 0.27 & 0.35 & 0.05 & 0.25 & 6 & 452 & 0.37 \\
\hline C-312212 & GLOC-3_34-36 & 1.15 & 0.28 & 0.34 & 0.05 & 0.25 & 7 & 440 & 0.38 \\
\hline C-312189 & GLOC-3_36-38 & 1.14 & 0.28 & 0.33 & 0.04 & 0.26 & 7 & 438 & 0.34 \\
\hline C-312226 & GLOC-3_38-40 & 1.2 & 0.29 & 0.34 & 0.04 & 0.3 & 7 & 450 & 0.35 \\
\hline C-312194 & GLOC-3_40-42 & 1.16 & 0.27 & 0.33 & 0.05 & 0.25 & 7 & 443 & 0.34 \\
\hline C-312230 & GLOC-3_42-44 & 1.30 & 0.30 & 0.38 & 0.05 & 0.25 & 7 & 449 & 0.31 \\
\hline C-312219 & GLOC-3_44-46 & 1.17 & 0.26 & 0.35 & 0.04 & 0.25 & 7 & 441 & 0.27 \\
\hline C-312223 & GLOC-3_46-48 & 1.22 & 0.26 & 0.36 & 0.04 & 0.25 & 7 & 460 & 0.27 \\
\hline C-312203 & GLOC-3_48-50 & 1.20 & 0.24 & 0.37 & 0.03 & 0.25 & 7 & 468 & 0.26 \\
\hline C-312195 & GLOC-3_50-52 & 1.18 & 0.22 & 0.39 & 0.03 & 0.26 & 5 & 490 & 0.21 \\
\hline C-312209 & GLOC-3_52-54 & 1.21 & 0.22 & 0.41 & 0.03 & 0.28 & 5 & 514 & 0.20 \\
\hline C-312205 & GLOC-3_54-56 & 1.14 & 0.22 & 0.38 & 0.02 & 0.24 & 4 & 536 & 0.20 \\
\hline C-312206 & GLOC-3_56-58 & 1.11 & 0.21 & 0.37 & 0.02 & 0.22 & 3 & 497 & 0.18 \\
\hline C-312214 & GLOC-3_58-60 & 1.06 & 0.19 & 0.35 & 0.02 & 0.23 & 3 & 437 & 0.17 \\
\hline C-312213 & GLOC-3_60-62 & 1.09 & 0.20 & 0.36 & 0.02 & 0.23 & 3 & 439 & 0.20 \\
\hline C-312196 & GLOC-3_62-64 & 1.10 & 0.19 & 0.36 & 0.02 & 0.25 & 3 & 452 & 0.17 \\
\hline C-312222 & GLOC-3_64-66 & 1.12 & 0.20 & 0.36 & 0.02 & 0.22 & 3 & 444 & 0.19 \\
\hline C-312221 & GLOC-3_66-68 & 1.13 & 0.20 & 0.37 & 0.02 & 0.25 & 3 & 438 & 0.19 \\
\hline C-312227 & GLOC-3_68-70 & 1.09 & 0.19 & 0.35 & 0.01 & 0.23 & 3 & 419 & 0.17 \\
\hline C-312202 & GLOC-3_70-72 & 1.10 & 0.20 & 0.34 & 0.01 & 0.23 & 3 & 418 & 0.18 \\
\hline C-312220 & GLOC-3_72-74 & 1.14 & 0.21 & 0.35 & 0.01 & 0.24 & 3 & 431 & 0.18 \\
\hline
\end{tabular}


Table 1-5. Core sediment sample analyses for GLOC-3, Spring River upstream from Grand Lake O' the Cherokees. Analyses by ICP-AES/MS after four-acid digestion, except for forms of carbon.-Continued

[ICP-AES/MS, inductively coupled plasma-atomic emission spectroscopy/mass spectroscopy; cm, centimeter; \%, percent; ppm, parts per million; $\mathrm{n} / \mathrm{a}$, not applicable]

\begin{tabular}{|c|c|c|c|c|c|c|c|c|c|}
\hline Lab no. & Field no. & Cd ppm & Coppm & Cr ppm & Cu ppm & Ga ppm & In ppm & Li ppm & Mn ppm \\
\hline C-312208 & GLOC-3_0-2 & 6.1 & 6.8 & 25 & 10.7 & 4.23 & $<0.02$ & 13 & 357 \\
\hline C-312225 & GLOC-3_2-4 & 12.9 & 12.5 & 44 & 23.7 & 9.74 & 0.04 & 27 & 796 \\
\hline C-312231 & GLOC-3_4-6 & 8.6 & 8.7 & 33 & 15.2 & 6.83 & 0.04 & 19 & 477 \\
\hline C-312228 & GLOC-3_6-8 & 7.1 & 8.3 & 29 & 14 & 5.6 & 0.02 & 17 & 344 \\
\hline C-312224 & GLOC-3_8-10 & 8.2 & 9.9 & 34 & 16.6 & 6.92 & 0.03 & 21 & 404 \\
\hline C-312198 & GLOC-3_10-12 & 8.1 & 10.4 & 38 & 18.8 & 7.72 & 0.03 & 23 & 477 \\
\hline C-312200 & GLOC-3_12-14 & 12.2 & 14.8 & 48 & 22.9 & 11.1 & 0.04 & 30 & 573 \\
\hline C-312192 & GLOC-3_14-16 & 120 & 11.4 & 39 & 17.6 & 8.32 & 0.03 & 24 & 509 \\
\hline C-312188 & GLOC-3_16-18 & 11.0 & 9.9 & 36 & 18.5 & 7.52 & 0.03 & 21 & 481 \\
\hline C-312191 & GLOC-3_18-20 & 14.0 & 12.3 & 42 & 22.6 & 9.01 & 0.04 & 25 & 528 \\
\hline C-312218 & GLOC-3_20-22 & 15.4 & 17.7 & 46 & 24.9 & 10.4 & 0.04 & 28 & 573 \\
\hline C-312210 & GLOC-3_22-24 & 17.8 & 14.9 & 50 & 36.1 & 11.2 & 0.06 & 30 & 539 \\
\hline C-312211 & GLOC-3_24-26 & 21.1 & 13.6 & 51 & 38.3 & 10.3 & 0.05 & 28 & 513 \\
\hline C-312204 & GLOC-3_26-28 & 23.3 & 13.4 & 52 & 31.2 & 10.6 & 0.05 & 28 & 504 \\
\hline C-312216 & GLOC-3_28-30 & 26.6 & 13.7 & 55 & 32.3 & 10.8 & 0.05 & 29 & 530 \\
\hline C-312197 & GLOC-3_30-32 & 31.4 & 14.4 & 58 & 40.5 & 11.4 & 0.07 & 31 & 603 \\
\hline C-312215 & GLOC-3_32-34 & 28.7 & 13.9 & 59 & 39 & 11.6 & 0.06 & 30 & 522 \\
\hline C-312212 & GLOC-3_-34-36 & 29.4 & 13.9 & 59 & 38.7 & 11.6 & 0.06 & 31 & 472 \\
\hline C-312189 & GLOC-3_36-38 & 20.5 & 14.6 & 56 & 38.8 & 11.9 & 0.06 & 31 & 576 \\
\hline C-312226 & GLOC-3_38-40 & 23.7 & 14.7 & 56 & 43.7 & 11.9 & 0.06 & 33 & 627 \\
\hline C-312194 & GLOC-3_40-42 & 24.4 & 14.3 & 51 & 40 & 11.4 & 0.05 & 30 & 513 \\
\hline C-312230 & GLOC-3_42-44 & 23.5 & 14.5 & 53 & 38.2 & 11.3 & 0.05 & 33 & 634 \\
\hline C-312219 & GLOC-3_44-46 & 19.7 & 13.7 & 46 & 27.6 & 11 & 0.04 & 28 & 822 \\
\hline C-312223 & GLOC-3_46-48 & 20.0 & 12.9 & 46 & 25.1 & 10.9 & 0.04 & 28 & 778 \\
\hline C-312203 & GLOC-3_48-50 & 14.5 & 11.8 & 43 & 24.2 & 10.4 & 0.04 & 28 & 720 \\
\hline C-312195 & GLOC-3_50-52 & 8.0 & 9.8 & 40 & 17.6 & 9.65 & 0.03 & 27 & 579 \\
\hline C-312209 & GLOC-3_52-54 & 4.8 & 10.3 & 43 & 17.9 & 9.43 & 0.03 & 27 & 1,210 \\
\hline C-312205 & GLOC-3_54-56 & 2.0 & 8.7 & 42 & 17.5 & 9.91 & 0.04 & 26 & 662 \\
\hline C-312206 & GLOC-3_56-58 & 0.6 & 7.8 & 39 & 15.2 & 8.92 & 0.03 & 24 & 443 \\
\hline C-312214 & GLOC-3_58-60 & 0.4 & 6.4 & 37 & 13.4 & 8.11 & 0.02 & 23 & 554 \\
\hline C-312213 & GLOC-3_60-62 & 0.5 & 7.0 & 36 & 16.5 & 8.59 & 0.03 & 23 & 551 \\
\hline C-312196 & GLOC-3_62-64 & 0.3 & 6.7 & 35 & 13.6 & 8.34 & 0.03 & 23 & 516 \\
\hline C-312222 & GLOC-3_64-66 & 0.3 & 7.8 & 37 & 14.7 & 8.94 & 0.03 & 23 & 642 \\
\hline C-312221 & GLOC-3_66-68 & 0.3 & 8.7 & 37 & 15.9 & 8.52 & 0.03 & 24 & 663 \\
\hline C-312227 & GLOC-3_68-70 & 0.2 & 9.2 & 38 & 14.5 & 8.64 & 0.03 & 23 & 574 \\
\hline C-312202 & GLOC-3_70-72 & 0.3 & 9.8 & 36 & 14.5 & 8.82 & 0.03 & 24 & 609 \\
\hline C-312220 & GLOC-3_72-74 & 0.3 & 9.0 & 38 & 17.4 & 9.1 & 0.03 & 24 & 714 \\
\hline
\end{tabular}


Table 1-5. Core sediment sample analyses for GLOC-3, Spring River upstream from Grand Lake O' the Cherokees. Analyses by ICP-AES/MS after four-acid digestion, except for forms of carbon.-Continued

[ICP-AES/MS, inductively coupled plasma-atomic emission spectroscopy/mass spectroscopy; cm, centimeter; \%, percent; ppm, parts per million; $\mathrm{n} / \mathrm{a}$, not applicable]

\begin{tabular}{|c|c|c|c|c|c|c|c|c|}
\hline Lab no. & Field no. & Ni ppm & P ppm & $\mathrm{Pb}$ ppm & $\mathrm{Rb} p p m$ & Sr ppm & V ppm & Zn ppm \\
\hline C-312208 & GLOC-3_0-2 & 12.5 & 530 & 60.5 & 28.3 & 28.9 & 31 & 1,020 \\
\hline C-312225 & GLOC-3_2-4 & 21.1 & 1,000 & 130 & 68.5 & 56.9 & 62 & 1,820 \\
\hline C-312231 & GLOC-3 $4-6$ & 15.7 & 670 & 69.3 & 43.6 & 40.2 & 43 & 1,280 \\
\hline C-312228 & GLOC-3_6-8 & 14.6 & 610 & 76.5 & 39.2 & 36.1 & 38 & 1,250 \\
\hline C-312224 & GLOC-3_8-10 & 17.2 & 640 & 89.9 & 50.6 & 46.4 & 46 & 1,440 \\
\hline C-312198 & GLOC-3 $10-12$ & 19.7 & 810 & 95.1 & 55.1 & 49.4 & 52 & 1,380 \\
\hline C-312200 & GLOC-3_12-14 & 25.1 & 1,050 & 109 & 79.3 & 60.5 & 71 & 1,610 \\
\hline C-312192 & GLOC-3_14-16 & 21.4 & 710 & 103 & 56.9 & 51.8 & 51 & 1,630 \\
\hline C-312188 & GLOC-3_16-18 & 20.4 & 650 & 98.4 & 52.2 & 45.7 & 48 & 1,550 \\
\hline C-312191 & GLOC-3_18-20 & 24.2 & 770 & 122 & 60.9 & 51.1 & 58 & 1,710 \\
\hline C-312218 & GLOC-3_20-22 & 29.7 & 880 & 143 & 73.8 & 56.5 & 66 & 1,910 \\
\hline C-312210 & GLOC-3_22-24 & 28.1 & 900 & 196 & 78.1 & 59.8 & 70 & 2,180 \\
\hline C-312211 & GLOC-3_24-26 & 27 & 920 & 226 & 71.1 & 57.7 & 65 & 2,380 \\
\hline C-312204 & GLOC-3_26-28 & 28.5 & 960 & 176 & 74.2 & 58.5 & 67 & 2,470 \\
\hline C-312216 & GLOC-3_28-30 & 30.8 & 1,130 & 176 & 75.4 & 59.9 & 71 & 2,640 \\
\hline C-312197 & GLOC-3_30-32 & 32.9 & 1,430 & 173 & 79.8 & 62.8 & 71 & 2,980 \\
\hline C-312215 & GLOC-3 $32-34$ & 30.8 & 1,200 & 177 & 78.9 & 60.9 & 74 & 3,120 \\
\hline C-312212 & GLOC-3_34-36 & 30 & 950 & 172 & 79.3 & 60.5 & 75 & 3,240 \\
\hline C-312189 & GLOC-3_36-38 & 30.3 & 770 & 180 & 81.9 & 60.2 & 77 & 3,160 \\
\hline C-312226 & GLOC-3_38-40 & 31.3 & 740 & 207 & 84.1 & 63.3 & 76 & 3,300 \\
\hline C-312194 & GLOC-3_40-42 & 30.6 & 640 & 248 & 78.5 & 59.9 & 73 & 3,340 \\
\hline C-312230 & GLOC-3_42-44 & 31.4 & 640 & 208 & 80.5 & 67.2 & 77 & 3,250 \\
\hline C-312219 & GLOC-3_44-46 & 27.8 & 600 & 169 & 80 & 59.1 & 72 & 2,810 \\
\hline C-312223 & GLOC-3_46-48 & 28.1 & 590 & 157 & 82.7 & 60.5 & 73 & 2,400 \\
\hline C-312203 & GLOC-3_48-50 & 25.5 & 580 & 128 & 84.3 & 62.2 & 70 & 1,800 \\
\hline C-312195 & GLOC-3_50-52 & 21.7 & 480 & 84.6 & 78.7 & 63.4 & 66 & 1,060 \\
\hline C-312209 & GLOC-3_52-54 & 19.9 & 460 & 48.6 & 79.2 & 68.6 & 63 & 606 \\
\hline C-312205 & GLOC-3_54-56 & 17.4 & 390 & 25.2 & 81.7 & 65.9 & 65 & 297 \\
\hline C-312206 & GLOC-3_56-58 & 15.1 & 370 & 20 & 75.8 & 60.5 & 60 & 154 \\
\hline C-312214 & GLOC-3_58-60 & 13.8 & 310 & 18.3 & 66.9 & 55.9 & 52 & 114 \\
\hline C-312213 & GLOC-3_60-62 & 13.8 & 310 & 19.7 & 71.6 & 57.3 & 55 & 113 \\
\hline C-312196 & GLOC-3_62-64 & 13.3 & 290 & 19.1 & 68 & 57.8 & 54 & 100 \\
\hline C-312222 & GLOC-3_64-66 & 14 & 280 & 19.9 & 71.3 & 56.2 & 54 & 102 \\
\hline C-312221 & GLOC-3_66-68 & 14.6 & 260 & 20.2 & 71.1 & 58.8 & 54 & 100 \\
\hline C-312227 & GLOC-3_68-70 & 14.4 & 240 & 18.7 & 73.9 & 55 & 52 & 97 \\
\hline C-312202 & GLOC-3_70-72 & 14.3 & 230 & 17.4 & 74.7 & 54.9 & 52 & 100 \\
\hline C-312220 & GLOC-3_72-74 & 15.1 & 220 & 18.8 & 75.1 & 56.3 & 54 & 103 \\
\hline
\end{tabular}


Table 1-6. Core sediment sample analyses for GLOC-7, Grand Lake O' the Cherokees 4 kilometers downstream from Highway 2 bridge. Analyses by ICP-AES/MS after four-acid digestion, except for forms of carbon.

(Click to see Excel file.)

[ICP-AES/MS, inductively coupled plasma-atomic emission spectroscopy/mass spectroscopy; cm, centimeter; \%, percent; ppm, parts per million]

\begin{tabular}{|c|c|c|c|c|c|c|c|c|c|}
\hline Lab no. & Field no. & $\begin{array}{l}\text { Depth in } \\
\text { inches }\end{array}$ & $\begin{array}{l}\text { Depth } \\
\text { in } \mathrm{cm}\end{array}$ & $\begin{array}{l}\text { Total } \\
\text { C \% }\end{array}$ & $\begin{array}{c}\text { Carbonate } \\
\text { C \% }\end{array}$ & $\begin{array}{c}\text { Organic } \\
\text { C } \%\end{array}$ & Al \% & $\mathrm{Ca} \%$ & $\mathrm{Fe} \%$ \\
\hline C-312182 & GLOC-7_0-2 & 2 & 5 & 0.90 & 0.06 & 0.84 & 4.63 & 0.59 & 1.89 \\
\hline C-312172 & GLOC-7_2-4 & 4 & 10 & 0.92 & 0.04 & 0.88 & 4.56 & 0.51 & 1.87 \\
\hline C-312159 & GLOC-7_4-6 & 6 & 15 & 0.73 & 0.01 & 0.72 & 4.96 & 0.40 & 1.95 \\
\hline C-312160 & GLOC-7_6-8 & 8 & 20 & 1.04 & 0.01 & 1.03 & 5.76 & 0.46 & 2.54 \\
\hline C-312169 & GLOC-7_8-10 & 10 & 25 & 0.96 & 0.01 & 0.95 & 5.79 & 0.47 & 2.57 \\
\hline C-312154 & GLOC-7_10-12 & 12 & 30 & 0.71 & 0.01 & 0.70 & 5.21 & 0.43 & 2.14 \\
\hline C-312176 & GLOC-7_12-14 & 14 & 35 & 0.80 & 0.01 & 0.79 & 5.07 & 0.43 & 2.09 \\
\hline C-312183 & GLOC-7_14-16 & 16 & 40 & 0.88 & 0.02 & 0.86 & 5.44 & 0.48 & 2.40 \\
\hline C-312162 & GLOC-7_17-18 & 18 & 45 & 0.72 & 0.01 & 0.71 & 4.97 & 0.42 & 1.94 \\
\hline C-312151 & GLOC-7_18-20 & 20 & 50 & 0.91 & 0.05 & 0.86 & 5.75 & 0.62 & 2.44 \\
\hline C-312155 & GLOC-7_20-22 & 22 & 55 & 0.93 & 0.03 & 0.90 & 5.31 & 0.50 & 2.18 \\
\hline C-312158 & GLOC-7_22-24 & 24 & 60 & 0.79 & $<0.003$ & 0.79 & 5.01 & 0.47 & 2.03 \\
\hline C-312179 & GLOC-7_24-26 & 26 & 65 & 1.09 & 0.05 & 1.04 & 5.76 & 0.59 & 2.49 \\
\hline C-312167 & GLOC-7_26-28 & 28 & 70 & 1.28 & 0.09 & 1.19 & 5.66 & 0.64 & 2.53 \\
\hline C-312178 & GLOC-7_28-30 & 30 & 75 & 1.00 & 0.01 & 0.99 & 5.09 & 0.36 & 2.17 \\
\hline C-312170 & GLOC-7_30-32 & 32 & 80 & 0.84 & $<0.003$ & 0.84 & 3.91 & 0.23 & 1.57 \\
\hline C-312157 & GLOC-7_32-34 & 34 & 85 & 0.79 & $<0.003$ & 0.79 & 3.84 & 0.20 & 1.55 \\
\hline C-312163 & GLOC-7_34-36 & 36 & 90 & 0.83 & $<0.003$ & 0.83 & 3.96 & 0.21 & 1.60 \\
\hline C-312177 & GLOC-7_36-38 & 38 & 95 & 0.82 & $<0.003$ & 0.82 & 3.98 & 0.20 & 1.65 \\
\hline C-312168 & GLOC-7_38-40 & 40 & 100 & 0.80 & $<0.003$ & 0.80 & 4.02 & 0.20 & 1.73 \\
\hline C-312166 & GLOC-7_40-42 & 42 & 105 & 0.75 & $<0.003$ & 0.75 & 3.77 & 0.18 & 1.59 \\
\hline C-312173 & GLOC-7_42-44 & 44 & 110 & 0.76 & $<0.003$ & 0.76 & 4.11 & 0.19 & 1.80 \\
\hline C-312180 & GLOC-7_44-46 & 46 & 115 & 0.73 & $<0.003$ & 0.73 & 4.19 & 0.20 & 1.84 \\
\hline C-312171 & GLOC-7_46-48 & 48 & 120 & 0.73 & $<0.003$ & 0.73 & 4.29 & 0.20 & 1.74 \\
\hline C-312156 & GLOC-7_-48-50 & 50 & 125 & 0.64 & $<0.003$ & 0.64 & 4.30 & 0.19 & 1.83 \\
\hline C-312174 & GLOC-7_50-52 & 52 & 130 & 0.6 & $<0.003$ & 0.60 & 4.39 & 0.18 & 1.97 \\
\hline C-312161 & GLOC-7_52-54 & 54 & 135 & 0.55 & $<0.003$ & 0.55 & 4.49 & 0.19 & 2.03 \\
\hline
\end{tabular}


Table 1-6. Core sediment sample analyses for GLOC-7, Grand Lake O' the Cherokees 4 kilometers downstream from Highway 2 bridge. Analyses by ICP-AES/MS after four-acid digestion, except for forms of carbon.-Continued [ICP-AES/MS, inductively coupled plasma-atomic emission spectroscopy/mass spectroscopy; $\mathrm{cm}$, centimeter; \%, percent; ppm, parts per million]

\begin{tabular}{|c|c|c|c|c|c|c|c|c|c|}
\hline Lab no. & Field no. & $\mathrm{K} \%$ & $\mathrm{Mg} \%$ & $\mathrm{Na} \%$ & $\mathbf{S} \%$ & $\mathrm{Ti} \%$ & As ppm & Ba ppm & Bi ppm \\
\hline C-312182 & GLOC-7_0-2 & 1.42 & 0.34 & 0.66 & 0.06 & 0.22 & 6 & 447 & 0.18 \\
\hline C-312172 & GLOC-7_2-4 & 1.37 & 0.34 & 0.62 & 0.06 & 0.2 & 6 & 427 & 0.18 \\
\hline C-312159 & GLOC-7 $4-6$ & 1.49 & 0.36 & 0.68 & 0.04 & 0.22 & 5 & 474 & 0.20 \\
\hline C-312160 & GLOC-7_6-8 & 1.56 & 0.47 & 0.58 & 0.04 & 0.25 & 8 & 511 & 0.25 \\
\hline C-312169 & GLOC-7_8-10 & 1.60 & 0.48 & 0.60 & 0.03 & 0.25 & 6 & 521 & 0.26 \\
\hline C-312154 & GLOC-7_-10-12 & 1.57 & 0.41 & 0.69 & 0.02 & 0.22 & 5 & 501 & 0.21 \\
\hline C-312176 & GLOC-7_12-14 & 1.51 & 0.38 & 0.70 & 0.02 & 0.23 & 5 & 491 & 0.21 \\
\hline C-312183 & GLOC-7_-14-16 & 1.54 & 0.44 & 0.62 & 0.02 & 0.23 & 6 & 494 & 0.22 \\
\hline C-312162 & GLOC-7_-17-18 & 1.49 & 0.38 & 0.68 & 0.03 & 0.22 & 6 & 486 & 0.19 \\
\hline C-312151 & GLOC-7_- $18-20$ & 1.67 & 0.50 & 0.66 & 0.05 & 0.24 & 7 & 531 & 0.24 \\
\hline C-312155 & GLOC-7_20-22 & 1.48 & 0.40 & 0.63 & 0.04 & 0.2 & 6 & 484 & 0.23 \\
\hline C-312158 & GLOC-7 $722-24$ & 1.46 & 0.38 & 0.66 & 0.04 & 0.21 & 6 & 465 & 0.20 \\
\hline C-312179 & GLOC-7_24-26 & 1.57 & 0.47 & 0.60 & 0.05 & 0.25 & 7 & 509 & 0.25 \\
\hline C-312167 & GLOC-7_26-28 & 1.55 & 0.48 & 0.59 & 0.05 & 0.25 & 7 & 505 & 0.26 \\
\hline C-312178 & GLOC-7_28-30 & 1.43 & 0.40 & 0.51 & 0.04 & 0.23 & 6 & 475 & 0.21 \\
\hline C-312170 & GLOC-7 $70-32$ & 1.14 & 0.25 & 0.38 & 0.05 & 0.21 & 4 & 413 & 0.17 \\
\hline C-312157 & GLOC-7_32-34 & 1.10 & 0.24 & 0.34 & 0.03 & 0.19 & 4 & 396 & 0.16 \\
\hline C-312163 & GLOC-7 $34-36$ & 1.10 & 0.25 & 0.35 & 0.03 & 0.2 & 4 & 410 & 0.17 \\
\hline C-312177 & GLOC-7_36-38 & 1.11 & 0.25 & 0.34 & 0.02 & 0.2 & 5 & 400 & 0.17 \\
\hline C-312168 & GLOC-7_38-40 & 1.09 & 0.25 & 0.32 & 0.02 & 0.2 & 5 & 407 & 0.17 \\
\hline C-312166 & GLOC-7_40-42 & 1.02 & 0.23 & 0.29 & 0.02 & 0.2 & 4 & 390 & 0.16 \\
\hline C-312173 & GLOC-7_42-44 & 1.10 & 0.25 & 0.31 & 0.02 & 0.2 & 5 & 407 & 0.17 \\
\hline C-312180 & GLOC-7 $44-46$ & 1.11 & 0.26 & 0.30 & 0.02 & 0.22 & 6 & 414 & 0.18 \\
\hline C-312171 & GLOC-7_46-48 & 1.12 & 0.26 & 0.30 & 0.03 & 0.2 & 4 & 432 & 0.18 \\
\hline C-312156 & GLOC-7 $48-50$ & 1.10 & 0.26 & 0.29 & 0.02 & 0.18 & 4 & 428 & 0.18 \\
\hline C-312174 & GLOC-7_50-52 & 1.12 & 0.27 & 0.28 & 0.02 & 0.22 & 5 & 429 & 0.18 \\
\hline C-312161 & GLOC-7 $52-54$ & 1.13 & 0.28 & 0.28 & 0.02 & 0.22 & 6 & 432 & 0.19 \\
\hline
\end{tabular}


Table 1-6. Core sediment sample analyses for GLOC-7, Grand Lake O' the Cherokees 4 kilometers downstream from Highway 2 bridge. Analyses by ICP-AES/MS after four-acid digestion, except for forms of carbon.-Continued [ICP-AES/MS, inductively coupled plasma-atomic emission spectroscopy/mass spectroscopy; cm, centimeter; \%, percent; ppm, parts per million]

\begin{tabular}{clcccccccc}
\hline Lab no. & Field no. & Cd ppm & Co ppm & Cr ppm & Cu ppm & Ga ppm & In ppm & Li ppm & Mn ppm \\
\hline C-312182 & GLOC-7_0-2 & 1.8 & 9.1 & 40 & 17.7 & 10.0 & 0.04 & 25 & 384 \\
C-312172 & GLOC-7_2-4 & 2.2 & 9.5 & 40 & 15.8 & 10.7 & 0.03 & 25 & 366 \\
C-312159 & GLOC-7_4-6 & 1.4 & 8.2 & 41 & 16.3 & 10.8 & 0.04 & 26 & 385 \\
C-312160 & GLOC-7_6-8 & 4.6 & 11.2 & 55 & 23.8 & 13.2 & 0.05 & 34 & 612 \\
C-312169 & GLOC-7_8-10 & 2.6 & 11.1 & 53 & 23.0 & 13.8 & 0.04 & 33 & 598 \\
C-312154 & GLOC-7_10-12 & 1.3 & 8.3 & 44 & 18.0 & 11.2 & 0.04 & 28 & 489 \\
C-312176 & GLOC-7_12-14 & 2.2 & 8.7 & 43 & 16.5 & 11.6 & 0.04 & 27 & 458 \\
C-312183 & GLOC-7_14-16 & 1.1 & 9.6 & 68 & 18.9 & 12.5 & 0.05 & 30 & 730 \\
C-312162 & GLOC-7_17-18 & 0.7 & 8.4 & 43 & 14.2 & 11.2 & 0.04 & 27 & 403 \\
C-312151 & GLOC-7_18-20 & 1.0 & 10.0 & 54 & 17.0 & 12.1 & 0.05 & 33 & 636 \\
C-312155 & GLOC-7_20-22 & 2.4 & 9.0 & 49 & 17.5 & 11.8 & 0.04 & 29 & 565 \\
C-312158 & GLOC-7_22-24 & 1.6 & 8.7 & 44 & 19.0 & 10.4 & 0.04 & 28 & 582 \\
C-312179 & GLOC-7_24-26 & 3.7 & 10.8 & 55 & 20.3 & 13.6 & 0.05 & 33 & 678 \\
C-312167 & GLOC-7_26-28 & 4.3 & 11.4 & 54 & 20.9 & 13.3 & 0.05 & 33 & 1,000 \\
C-312178 & GLOC-7_28-30 & 1.5 & 10.0 & 46 & 18.0 & 11.8 & 0.04 & 29 & 436 \\
C-312170 & GLOC-7_30-32 & 0.6 & 8.0 & 38 & 15.2 & 8.89 & 0.03 & 23 & 302 \\
C-312157 & GLOC-7_32-34 & 0.3 & 7.0 & 38 & 13.5 & 8.39 & 0.03 & 22 & 323 \\
C-312163 & GLOC-7_34-36 & 0.4 & 7.5 & 37 & 14.3 & 8.94 & 0.03 & 23 & 338 \\
C-312177 & GLOC-7_36-38 & 0.4 & 7.5 & 36 & 14.7 & 9.15 & 0.03 & 23 & 359 \\
C-312168 & GLOC-7_38-40 & 0.3 & 7.7 & 39 & 17.6 & 9.12 & 0.03 & 23 & 378 \\
C-312166 & GLOC-7_40-42 & 0.4 & 7.3 & 41 & 12.4 & 8.89 & 0.03 & 22 & 361 \\
C-312173 & GLOC-7_42-44 & 0.3 & 8.0 & 42 & 16.0 & 9.35 & 0.03 & 24 & 417 \\
C-312180 & GLOC-7_44-46 & 0.3 & 8.5 & 45 & 13.5 & 9.55 & 0.03 & 25 & 441 \\
C-312171 & GLOC-7_46-48 & 0.4 & 8.8 & 42 & 17.7 & 9.75 & 0.03 & 26 & 437 \\
C-312156 & GLOC-7_48-50 & 0.3 & 8.5 & 43 & 15.5 & 9.02 & 0.03 & 25 & 477 \\
C-312174 & GLOC-7_50-52 & 0.4 & 9.6 & 43 & 17.0 & 9.95 & 0.03 & 27 & 508 \\
C-312161 & GLOC-7_52-54 & 0.2 & 10.2 & 44 & 16.2 & 9.82 & 0.04 & 26 & 527 \\
& & & & & & & & &
\end{tabular}


Table 1-6. Core sediment sample analyses for GLOC-7, Grand Lake O' the Cherokees 4 kilometers downstream from Highway 2 bridge. Analyses by ICP-AES/MS after four-acid digestion, except for forms of carbon.-Continued [ICP-AES/MS, inductively coupled plasma-atomic emission spectroscopy/mass spectroscopy; cm, centimeter; \%, percent; ppm, parts per million]

\begin{tabular}{clccccccc}
\hline Lab no. & Field no. & Ni ppm & P ppm & Pb ppm & Rb ppm & Sr ppm & V ppm & Zn ppm \\
\hline C-312182 & GLOC-7_0-2 & 18.1 & 540 & 28.1 & 73.9 & 93.8 & 63 & 336 \\
C-312172 & GLOC-7_2-4 & 18.3 & 520 & 29.2 & 77.9 & 90.0 & 63 & 362 \\
C-312159 & GLOC-7_4-6 & 19.5 & 530 & 27.7 & 80.1 & 94.4 & 68 & 231 \\
C-312160 & GLOC-7_6-8 & 23.8 & 840 & 53.9 & 95.0 & 97.6 & 85 & 463 \\
C-312169 & GLOC-7_8-10 & 24.4 & 760 & 36.8 & 97.0 & 98.4 & 84 & 339 \\
C-312154 & GLOC-7_10-12 & 20.5 & 580 & 21.9 & 84.0 & 99.3 & 72 & 160 \\
C-312176 & GLOC-7_12-14 & 19.4 & 510 & 25.1 & 85.0 & 99.4 & 70 & 211 \\
C-312183 & GLOC-7_14-16 & 24.8 & 610 & 24.9 & 90.3 & 98.7 & 77 & 166 \\
C-312162 & GLOC-7_17-18 & 19.4 & 460 & 20.1 & 80.3 & 98.3 & 67 & 152 \\
C-312151 & GLOC-7_18-20 & 24.6 & 550 & 22.3 & 89.1 & 108 & 80 & 190 \\
C-312155 & GLOC-7_20-22 & 22.5 & 590 & 32.5 & 86.0 & 97.0 & 76 & 315 \\
C-312158 & GLOC-7_22-24 & 20.7 & 560 & 24.1 & 77.0 & 95.8 & 66 & 275 \\
C-312179 & GLOC-7_24-26 & 25.1 & 680 & 34.9 & 95.0 & 102 & 81 & 542 \\
C-312167 & GLOC-7_26-28 & 25.2 & 620 & 35.9 & 92.5 & 103 & 82 & 554 \\
C-312178 & GLOC-7_28-30 & 22.1 & 500 & 24.3 & 87.5 & 84.8 & 74 & 231 \\
C-312170 & GLOC-7_30-32 & 16.8 & 310 & 19.6 & 70.3 & 62.5 & 59 & 101 \\
C-312157 & GLOC-7_32-34 & 16.1 & 300 & 17.8 & 64.0 & 57.3 & 58 & 75 \\
C-312163 & GLOC-7_34-36 & 17.2 & 310 & 18.7 & 69.9 & 58.1 & 61 & 87 \\
C-312177 & GLOC-7_36-38 & 16.9 & 300 & 19.2 & 69.8 & 56.5 & 60 & 84 \\
C-312168 & GLOC-7_38-40 & 18.1 & 320 & 19.6 & 68.5 & 57.6 & 60 & 74 \\
C-312166 & GLOC-7_40-42 & 17.8 & 290 & 17.5 & 65.5 & 50.8 & 59 & 67 \\
C-312173 & GLOC-7_42-44 & 18.2 & 300 & 18.3 & 69.8 & 57.1 & 63 & 67 \\
C-312180 & GLOC-7_44-46 & 20.2 & 300 & 19.0 & 71.0 & 56.6 & 63 & 69 \\
C-312171 & GLOC-7_46-48 & 19.5 & 290 & 18.7 & 69.4 & 53.8 & 64 & 67 \\
C-312156 & GLOC-7_48-50 & 19.9 & 290 & 18.9 & 66.7 & 52.6 & 64 & 70 \\
C-312174 & GLOC-7_50-52 & 19.5 & 280 & 20.4 & 71.4 & 53.2 & 67 & 64 \\
C-312161 & GLOC-7_52-54 & 20.3 & 270 & 20.0 & 71.3 & 52.4 & 68 & 64 \\
\hline
\end{tabular}


Table 1-7. Core sediment sample analyses for GLOC-8, Grand Lake O' the Cherokees at confluence of Spring and Neosho Rivers. Analyses by ICP-AES/MS after four-acid digestion, except for forms of carbon.

(Click to see Excel file.)

[ICP-AES/MS, inductively coupled plasma-atomic emission spectroscopy/mass spectroscopy; cm, centimeter; \%, percent; ppm, parts per million]

\begin{tabular}{|c|c|c|c|c|c|c|c|c|c|c|}
\hline Lab no. & Field no. & $\begin{array}{c}\text { Depth in } \\
\text { inches }\end{array}$ & $\begin{array}{l}\text { Depth } \\
\text { in cm }\end{array}$ & $\begin{array}{l}\text { Total } \\
\mathrm{C} \% \\
\end{array}$ & $\begin{array}{c}\text { Carbonat } \\
\mathrm{C} \%\end{array}$ & & $\begin{array}{c}\text { Organic } \\
\text { C \% }\end{array}$ & $\mathrm{Al} \%$ & $\mathrm{Ca} \%$ & $\mathrm{Fe} \%$ \\
\hline C-310682 & GLOC-8_1-3 & 2 & 5 & 1.1 & 0.02 & & 1.08 & 4.95 & 0.47 & 2.27 \\
\hline C-310709 & GLOC-8_3-5 & 4 & 10 & 1.15 & 0.01 & & 1.14 & 5.32 & 0.49 & 2.41 \\
\hline C-310717 & GLOC-8_5-7 & 6 & 15 & 1.13 & 0.01 & & 1.12 & 5.2 & 0.46 & 2.37 \\
\hline C-310695 & GLOC-8_7-9 & 8 & 20 & 1.61 & $<0.003$ & & 1.61 & 5.84 & 0.42 & 2.51 \\
\hline C-310692 & GLOC-8_9-11 & 10 & 25 & 1.2 & 0.01 & & 1.19 & 5.41 & 0.44 & 2.5 \\
\hline C-310697 & GLOC-8_11-13 & 12 & 30 & 1.39 & $<0.003$ & & 1.39 & 5.82 & 0.44 & 2.69 \\
\hline C-310715 & GLOC-8_13-15 & 14 & 35 & 1.38 & 0.01 & & 1.37 & 5.26 & 0.39 & 2.34 \\
\hline C-310701 & GLOC-8 $\quad 15-17$ & 16 & 40 & 1.17 & 0.01 & & 1.16 & 3.89 & 0.3 & 1.6 \\
\hline C-310704 & GLOC-8_17-19 & 18 & 45 & 1.25 & 0.01 & & 1.24 & 3.81 & 0.29 & 1.54 \\
\hline C-310691 & GLOC-8_19-21 & 20 & 50 & 1.27 & 0.03 & & 1.24 & 3.95 & 0.32 & 1.71 \\
\hline C-310687 & GLOC-8 $21-23$ & 22 & 55 & 1.13 & 0.01 & & 1.12 & 4.19 & 0.32 & 1.75 \\
\hline C-310699 & GLOC-8_23-25 & 24 & 60 & 1.34 & 0.03 & & 1.31 & 5.13 & 0.67 & 2.5 \\
\hline C-310694 & GLOC-8_25-27 & 26 & 65 & 0.86 & 0.01 & & 0.85 & 4.27 & 0.33 & 1.72 \\
\hline C-310683 & GLOC-8_27-29 & 28 & 70 & 0.74 & $<0.003$ & & 0.74 & 4.1 & 0.31 & 1.52 \\
\hline C-310689 & GLOC-8_29-31 & 30 & 75 & 0.53 & $<0.003$ & & 0.53 & 3.97 & 0.29 & 1.53 \\
\hline Lab no. & Field no. & $\mathrm{K} \%$ & $\mathrm{Mg} \%$ & $\mathrm{Na} \%$ & $\mathbf{S} \%$ & $\mathrm{Ti} \%$ & As ppm & & a ppm & Bi ppm \\
\hline C-310682 & GLOC-8_1-3 & 1.29 & 0.36 & 0.46 & 0.04 & 0.23 & 7 & & 453 & 0.25 \\
\hline C-310709 & GLOC-8_3-5 & 1.35 & 0.4 & 0.47 & 0.04 & 0.24 & 7 & & 468 & 0.27 \\
\hline C-310717 & GLOC-8_5-7 & 1.31 & 0.38 & 0.44 & 0.04 & 0.24 & 6 & & 473 & 0.28 \\
\hline C-310695 & GLOC-8_7-9 & 1.35 & 0.38 & 0.38 & 0.04 & 0.28 & 7 & & 509 & 0.38 \\
\hline C-310692 & GLOC-8_9-11 & 1.21 & 0.39 & 0.4 & 0.04 & 0.24 & 7 & & 476 & 0.31 \\
\hline C-310697 & GLOC-8_11-13 & 1.41 & 0.43 & 0.42 & 0.04 & 0.26 & 7 & & 491 & 0.33 \\
\hline C-310715 & GLOC-8_13-15 & 1.31 & 0.35 & 0.42 & 0.04 & 0.26 & 6 & & 482 & 0.3 \\
\hline C-310701 & GLOC-8_15-17 & 1.18 & 0.21 & 0.42 & 0.03 & 0.23 & 4 & & 474 & 0.18 \\
\hline C-310704 & GLOC-8_17-19 & 1.14 & 0.22 & 0.4 & 0.03 & 0.22 & 4 & & 458 & 0.19 \\
\hline C-310691 & GLOC-8_19-21 & 1.16 & 0.22 & 0.41 & 0.03 & 0.23 & 5 & & 473 & 0.19 \\
\hline C-310687 & GLOC-8_21-23 & 1.13 & 0.23 & 0.4 & 0.04 & 0.23 & 6 & & 506 & 0.2 \\
\hline C-310699 & GLOC-8_23-25 & 1.12 & 0.4 & 0.24 & 0.09 & 0.25 & 9 & & 409 & 0.29 \\
\hline C-310694 & GLOC-8_25-27 & 1.2 & 0.25 & 0.42 & 0.02 & 0.24 & 4 & & 483 & 0.19 \\
\hline C-310683 & GLOC-8_27-29 & 1.2 & 0.24 & 0.44 & 0.03 & 0.24 & 4 & & 528 & 0.19 \\
\hline C-310689 & GLOC-8_29-31 & 1.2 & 0.23 & 0.43 & 0.01 & 0.21 & 3 & & 487 & 0.19 \\
\hline
\end{tabular}


Table 1-7. Core sediment sample analyses for GLOC-8, Grand Lake O' the Cherokees at confluence of Spring and Neosho Rivers. Analyses by ICP-AES/MS after four-acid digestion, except for forms of carbon.-Continued [ICP-AES/MS, inductively coupled plasma-atomic emission spectroscopy/mass spectroscopy; cm, centimeter; \%, percent; ppm, parts per million]

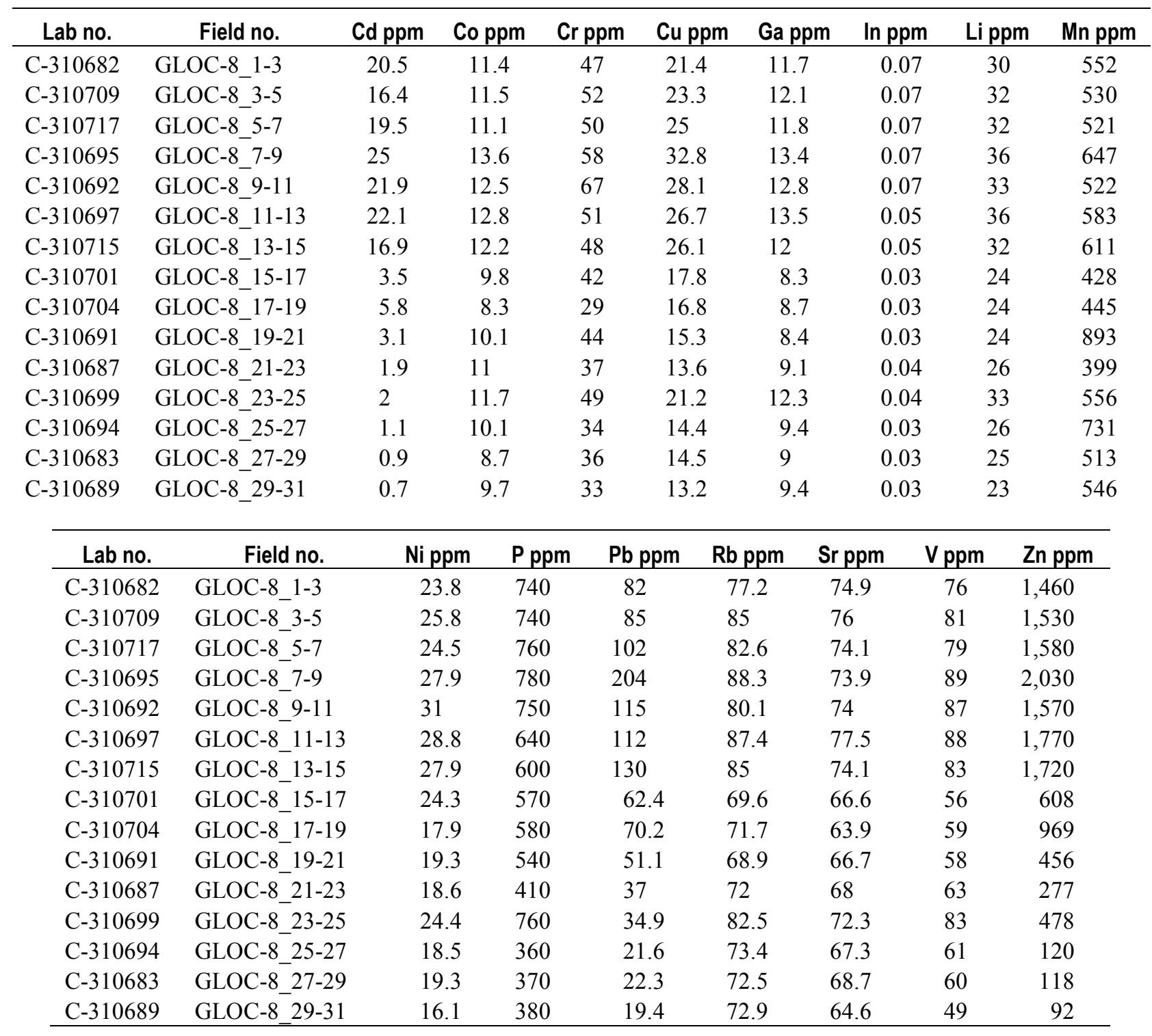




\section{Appendix 2. Data Quality Control and Quality Assessment}

\section{Sources of Geochemical Variation and Methods for Assuring Data Quality}

There are several potential sources and levels of variation in geochemical data-for instance, between-site variation, within-site variation, sample inhomogeneity, and analytical variation. A complete analysis of variation (ANOVA) sampling design generally shows that the primary variation in geochemical data is that found between individual samples at different and widely spaced sites (between-site variation). This variation is due to differences in sample parent material, local geology, mineralization processes (Rose and others, 1979), and possible anthropogenic influences. This variation provides areal geochemical contrasts and is the basis upon which geochemical exploration programs operate.

The next level of geochemical variation is known as within-site variation. This variation can be reduced by compositing several subsamples within the immediate area of sample collection, resulting in a more representative sample of the entire site. Variation is also found within any single sample due to the heterogeneity of the sampled material. This sample variation can be reduced by good sample preparation procedures (Fey and others, 2009). A process of crushing, grinding, mixing, and splitting the sample typically creates a very fine homogenous powder from the original heterogeneous material. All of the sample preparation processes were performed by USGS personnel in either Oklahoma City or Denver. Laboratory analytical procedures also can be sources of variation in the geochemical data. These sources include differences in analysts, dissolution procedures, analytical instruments, instrument calibration errors, and instrument drift. The combined variation due to sample preparation, aliquot size, and analytical procedures (commonly called analytical variation) can be assessed by using standard reference materials, analytical duplicates, and procedure blanks (Dux, 1986)

\section{Quality Control Samples}

The SGS Minerals Services contract laboratory analyzed quality control samples along with the field samples. The SGS laboratories are ISO 17025 accredited, certified by the International Organization for Standardization (ISO). A standard reference material (SRM) was run for every 20 samples; this material was the Canadian soil standard CCRMP SO-3 (Canadian Certified Reference Materials Project: $h t t p: / / w w w . n r c a n . g c . c a / s m m-m m s / t e c t-t e c h / c c r m p / c e r-c e r / s o-2-e n g . h t m)$. Laboratory personnel also processed and analyzed about one out of every 20 samples twice as analytical duplicates. Procedure blanks, which are solutions of the acid reagents carried through the entire process, were also analyzed at a rate of one for every 20 samples. In this study, the data for these laboratory internal quality control samples were requested from the contract laboratory so that the analytical variation could be assessed.

In addition to the SGS internal laboratory quality-control samples, the USGS submitted additional quality control samples as blind samples. These included sample splits for analytical duplicates (for precision assessment), three National Institute of Standards and Technology (NIST) standards (NIST-2709, NIST-2711, and NIST-8704), and a suite of USGS-prepared standard reference materials (SAR-L, SAR-M, DGPM-1, and GSP-QC) ${ }^{1}$ (for precision and accuracy assessment). These blind quality control samples were submitted to SGS Minerals Services at a rate of ten percent.

\footnotetext{
${ }^{1}$ SAR-L and SAR-M: sediment, Animas River watershed, Colo., low and moderate levels of contaminant constituents, respectively; DGPM-1: disseminated gold ore, Pinson Mine, Nev.; GSP-QC: granodiorite, Silver Plume, Colo.
} 


\section{Quality Assurance/Quality Control Measurement}

A quality management system for a geochemical survey includes both quality assurance (QA) and quality control (QC) elements. The QA focus is mainly in the analytical laboratory environment. Under the QA umbrella, the components of standard operating procedures, instrument logs, training records, data acceptance/rejection criteria, and lab audits are covered (Dux, 1986). The QA element is not easily measured. However, the QC element provides measures of the accuracy and precision of geochemical data produced by an analytical method. The precision of an analytical method can be measured by the percent relative standard deviation (percent RSD) of data for a number of runs of a particular sample or standard; it is calculated by dividing the standard deviation (SD) by the mean and multiplying by 100 . This most common version of the SD is defined as the square root of the quantity \{"sum of squares of deviations of individual results from the mean, divided by one less than the number of results in the set"' (Dux, 1986):

$$
S D=\sqrt{\sum_{i=1}^{n}\left(X_{i}-\bar{X}\right)^{2} / n-1}
$$

This precision was calculated for each element, for each SRM. The resulting eight precision values were then pooled together to derive an overall RSD for each element, using the following relation:

$S D_{\text {pooled }}=\sqrt{ }\left\{\left(n_{1} S D_{1}^{2}+n_{2} S D_{2}^{2}+n_{3} S D_{3}^{2}+n_{4} S D_{4}^{2}+n_{5} S D_{5}{ }^{2}+n_{6} S D_{6}{ }^{2}+n_{7} S D_{7}{ }^{2}+n_{8} S D_{8}{ }^{2}\right) /\left(n_{1}+n_{2}+n_{3}+n_{4}+n_{5}+n_{6}+n_{7}+n_{8}\right)\right\}$

Where $n_{1 \ldots 8}=$ number of pairs for a particular element, and $S D_{1 \ldots 8}=$ individual standard deviation calculated for each SRM and element. The precision as represented by the percent RSD calculated from this method is shown in column 8 of table $2-1$. 
Table 2-1. Summary statistics for assessing analytical precision for carbonate carbon, total carbon, and 26 elements by ICP-AES/MS. Percent RSD, mean of relative percent differences, and pooled standard deviation are three separate measurements of analytical precision. (Click to see Excel file.)

[ICP-AES/MS, inductively coupled plasma-atomic emission spectroscopy/mass spectroscopy; RPD, relative percent differences; RSD, relative standard deviation; SRMS, standard reference materials; \%, percent; ppm, parts per million]

\begin{tabular}{|c|c|c|c|c|c|c|c|c|c|}
\hline Element & Unit & $\begin{array}{l}\text { Pairs } \\
\text { (k) }\end{array}$ & Min & Max & Mean & $\begin{array}{l}\text { Standard } \\
\text { deviation } \\
\text { based on } \\
\text { duplicates }\end{array}$ & $\begin{array}{c}\text { Percent } \\
\text { RSD } \\
\text { based on } \\
\text { duplicate } \\
\text { pairs } \\
\end{array}$ & $\begin{array}{l}\text { Mean of } \\
\text { RPD } \\
\text { between } \\
\text { pairs }\end{array}$ & $\begin{array}{c}\text { Percent } \\
\text { RSD } \\
\text { based on } \\
\text { SRMS } \\
\text { (pooled) }\end{array}$ \\
\hline Carbonate & & & & & & & & & \\
\hline $\mathrm{C}$ & $\%$ & 22 & 0.003 & 1.47 & 0.03 & 0.0067 & 2.00 & 20.0 & 14.0 \\
\hline Total C & $\%$ & 25 & 0.27 & 1.55 & 0.90 & 0.0179 & 1.99 & 2.21 & 4.56 \\
\hline $\mathrm{Al}$ & $\%$ & 25 & 2.94 & 6.16 & 4.56 & 0.0780 & 1.71 & 1.90 & 2.61 \\
\hline $\mathrm{Ca}$ & $\%$ & 25 & 0.18 & 0.79 & 0.37 & 0.0087 & 2.36 & 2.70 & 2.38 \\
\hline $\mathrm{Fe}$ & $\%$ & 25 & 1.39 & 2.64 & 1.96 & 0.0352 & 1.79 & 2.02 & 2.88 \\
\hline $\mathrm{K}$ & $\%$ & 25 & 0.77 & 1.57 & 1.26 & 0.0220 & 1.75 & 1.81 & 3.13 \\
\hline $\mathrm{Mg}$ & $\%$ & 25 & 0.17 & 0.51 & 0.31 & 0.0071 & 2.25 & 2.39 & 2.65 \\
\hline $\mathrm{Na}$ & $\%$ & 25 & 0.22 & 0.68 & 0.43 & 0.0088 & 2.03 & 2.29 & 3.59 \\
\hline $\mathrm{S}$ & $\%$ & 23 & 0.01 & 0.06 & 0.04 & 0.0000 & 0.00 & 0.00 & 4.20 \\
\hline $\mathrm{Ti}$ & $\%$ & 25 & 0.16 & 0.26 & 0.22 & 0.0132 & 6.12 & 6.64 & 5.18 \\
\hline As & ppm & 25 & 3.0 & 9.0 & 5.59 & 0.616 & 11.0 & 7.04 & 9.20 \\
\hline $\mathrm{Ba}$ & ppm & 25 & 299 & 527 & 432 & 8.71 & 2.02 & 2.18 & 1.88 \\
\hline $\mathrm{Bi}$ & ppm & 20 & 0.15 & 0.39 & 0.22 & 0.010 & 4.46 & 5.60 & 15.5 \\
\hline $\mathrm{Cd}$ & ppm & 25 & 0.2 & 24.4 & 4.00 & 0.317 & 7.92 & 9.78 & 19.0 \\
\hline $\mathrm{Co}$ & ppm & 25 & 7.0 & 14.3 & 10.0 & 0.370 & 3.69 & 3.82 & 11.6 \\
\hline $\mathrm{Cr}$ & ppm & 25 & 32 & 59 & 45.2 & 2.63 & 5.83 & 5.46 & 7.66 \\
\hline $\mathrm{Cu}$ & ppm & 25 & 12.3 & 40 & 18.3 & 0.932 & 5.09 & 5.52 & 6.96 \\
\hline $\mathrm{Ga}$ & ppm & 25 & 6.92 & 14.6 & 10.6 & 0.283 & 2.68 & 2.98 & 8.77 \\
\hline In & ppm & 25 & 0.03 & 0.07 & 0.04 & 0.003 & 8.03 & 3.69 & 13.5 \\
\hline $\mathrm{Li}$ & ppm & 25 & 19 & 36 & 26.3 & 0.693 & 2.63 & 3.08 & 3.53 \\
\hline $\mathrm{Mn}$ & ppm & 25 & 323 & 980 & 543 & 15.5 & 2.86 & 2.83 & 4.39 \\
\hline $\mathrm{Ni}$ & ppm & 25 & 14 & 32.6 & 22.0 & 1.26 & 5.70 & 5.19 & 9.94 \\
\hline $\mathrm{P}$ & ppm & 25 & 230 & 930 & 503 & 12.6 & 2.52 & 2.45 & 2.69 \\
\hline $\mathrm{Pb}$ & ppm & 25 & 15 & 248 & 52.7 & 2.58 & 4.89 & 3.99 & 6.00 \\
\hline $\mathrm{Rb}$ & ppm & 25 & 50.1 & 100 & 75.1 & 2.18 & 2.91 & 2.80 & 6.52 \\
\hline $\mathrm{Sr}$ & ppm & 25 & 37.4 & 116 & 74.4 & 1.43 & 1.93 & 2.39 & 1.92 \\
\hline $\mathrm{V}$ & ppm & 25 & 46 & 91 & 67.4 & 1.21 & 1.79 & 1.59 & 2.64 \\
\hline $\mathrm{Zn}$ & ppm & 25 & 48 & 3,500 & 586 & 32.0 & 5.47 & 3.10 & 3.67 \\
\hline
\end{tabular}


A second way to assess the precision of a technique is to calculate the average of the relative percent differences (RPDs) between pairs of duplicate measurements: samples that were split in the laboratory after field collection and then processed and analyzed as two separate samples. In this study, there were 25 pairs of duplicate measurements for most elements. The version of precision thus calculated is:

$$
\text { Precision } \left.=\left\{\text { Average of } \sum\left(\text { absolute value }\left(X_{1}-X_{2}\right) /\left(X_{1}+X_{2}\right)\right) / 2\right)\right\} * 100
$$

where $X_{1}$ and $X_{2}$ are the measurement values of each duplicate pair. This precision is shown in column 9 of table $2-1$.

Another way to estimate precision from analytical duplicate pairs is to calculate the standard deviation as the square root of the quantity s sum of squares of the difference between the duplicate results $(\mathrm{R})$, divided by two times the number of sets of duplicate samples\} (Dux, 1986).

$$
S D_{\text {dupe }}=\sqrt{\sum R^{2} / 2 k}
$$

The percent RSD is then again calculated by dividing the standard deviation $\left(\mathrm{SD}_{\text {dupe }}\right)$ by the mean and multiplying by 100 . This third estimate for precision in this study is shown in column 10 of table $2-1$.

The accuracy of an analytical method is measured by the percent recovery, which is calculated by dividing the mean concentration of replicate analyses by the target value of the standard reference material used and multiplying by 100 . Target values for standard reference materials may consist of certified values or, when certified values are not available, informational values. The percent recovery derived from informational values is not as reliable as the percent recovery calculated from certified values, but it is still useful. In general, analytical determinations become less accurate and precise as data values approach the lower or upper reporting limits. Measurements of precision and accuracy are best when elemental concentrations fall within the middle of the determination range for a specified analytical method and element. Percent RSD and percent recovery values are more robust when calculated on mean values greater than five times the method's lower reporting limit.

Possible contamination during the analytical procedure is assessed through the use of procedure blanks. Blanks are defined based on the sample medium and analytical method and are processed concurrently with samples to determine whether contamination has occurred during the sample dissolution stages or whether cross-sample contamination has occurred in the analytical instrument during a sample run. Commonly, blanks are a set of all the reagents used in the sample processing and analysis procedure. Procedure blanks were prepared, analyzed, and results provided by SGS Minerals to the USGS. The blank results are shown in table 1-1; they show no contamination effects from reagents or the analytical procedures.

\section{Quality Assessment of Data}

Eight different reference materials were analyzed with the samples for the ICP-AES/MS method. Five of these materials have certified values (NIST 2709, NIST 2711, NIST 8704, USGS DGPM-1, CCRMP SO-3), and three are in-house USGS materials that have been submitted to the contract laboratory over a period of years but do not have certified values (USGS SAR-L, USGS SAR-M, USGS GSP-QC). No single certified reference material covers all of the elements analyzed; the use of several different certified SRMs allowed for all elements except bismuth (Bi) and lithium (Li) to have certified accuracy (percent recovery) assessments calculated. Comparison of the concentration values for bismuth 
and lithium for USGS SAR-L, SAR-M, and GSP-QC with their respective historical values allowed for noncertified percent recovery calculations to be made for those two elements.

\section{Precision Analysis}

As outlined above, precision was calculated using three different approaches. Analysis of 25 duplicate pairs yielded a percent RSD and a mean of relative percent differences for all elements. Multiple analyses of each reference material allowed for a calculation of a percent RSD for each. These RSDs were then pooled to produce a third overall measure of precision for the dataset. The three calculated precision values are plotted in figure $2-1$. In general, the precision values mostly plot at better than $<10$ percent by all three methods. Tables $2-2$ through $2-9$ include columns for the standard deviation and percent relative standard deviation for each respective reference material. These are the values used in the pooled standard deviation calculation discussed above. A brief description follows for those elements whose RSD calculations were above ten percent for one or more of the precision parameters: carbonate carbon, arsenic, bismuth, cadmium, cobalt, indium, and nickel.

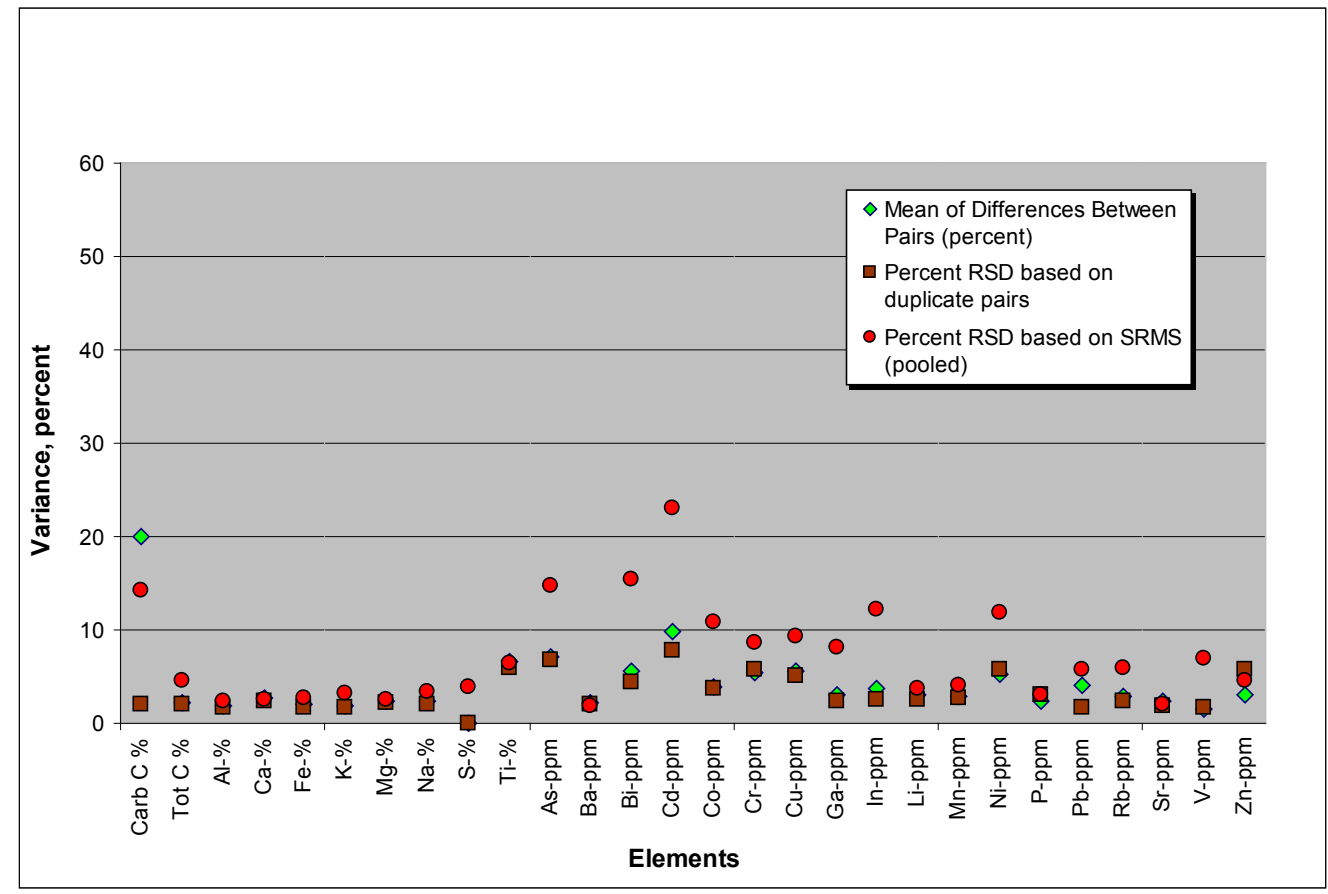

Figure 2-1. Precision plot for ICP-AES/MS and carbon analyses based on three estimates of variance. [ICP-AES/MS, inductively coupled plasma-atomic emission spectroscopy/mass spectroscopy; \%, percent; ppm, parts per million; RSD, relative standard deviation; SRMS, standard reference materials]

The high variability for carbonate carbon based on the mean of differences between pairs, 20 percent, is related to the weight contributed to the calculation from samples whose carbonate carbon contents are very low, near the detection limit. For example, the percent difference between duplicate analyses of 0.01 and 0.02 is 67 percent, whereas the percent difference between duplicate analyses of 1.15 and 1.13 is only 1.7 percent. Thus, the sample pairs with very low carbonate carbon tend to skew this calculation of the precision parameter. 
The pooled RSD for arsenic was 14.7 percent, but this value was skewed by the individual RSD for the reference material CCRMP SO-3, which was 29 percent. Discarding this one value resulted in a pooled RSD for arsenic of 8 percent.

The precision for bismuth based on the duplicate pairs and the mean of the RPDs is about 5 percent (table 2-1). The pooled RSD based on the eight reference materials is 15.5 percent. This greater value is influenced by those standards that had bismuth concentrations at less than $1 \mathrm{ppm}$. At this level, distributions of trace elements are much less homogeneous. The same situation and explanation applies to cadmium.

The pooled estimate for RSD for cobalt was 10.8 percent. A single outlier value for the SRM NIST 8704 of $5.1 \mathrm{ppm}$ versus a target of $13.6 \mathrm{ppm}$ resulted in this high RSD. Eliminating that outlier value results in a pooled RSD estimate for cobalt of 4.7 percent.

A single outlier value for the SRM NIST 8704 also influenced the pooled RSD estimate for indium. With the outlier the estimate is 12.2 percent. Removing the outlier $(0.03 \mathrm{ppm}$ versus a mean of $0.08 \mathrm{ppm}$ ) results in a pooled RSD estimate of 5.1 percent.

Accuracy Analysis

\section{SRM NIST 2709}

The SRM NIST 2709 was analyzed six times along with the samples. Table $2-2$ gives the percent RSD and percent recovery results for this standard, and figure 2-2 shows graphically the accuracy plot. Those elements that show " $\mathrm{n} / \mathrm{a}$ " in table 2-2 or have no symbol plotted on figure 2-2 do not have a certified value for comparison. All plotted elements except chromium and nickel fall within \pm 15 percent of the target values. The chromium recovery is low, 76 percent, due to the difficulty of the four-acid digestion to dissolve the refractory mineral phase in which chromium resides.

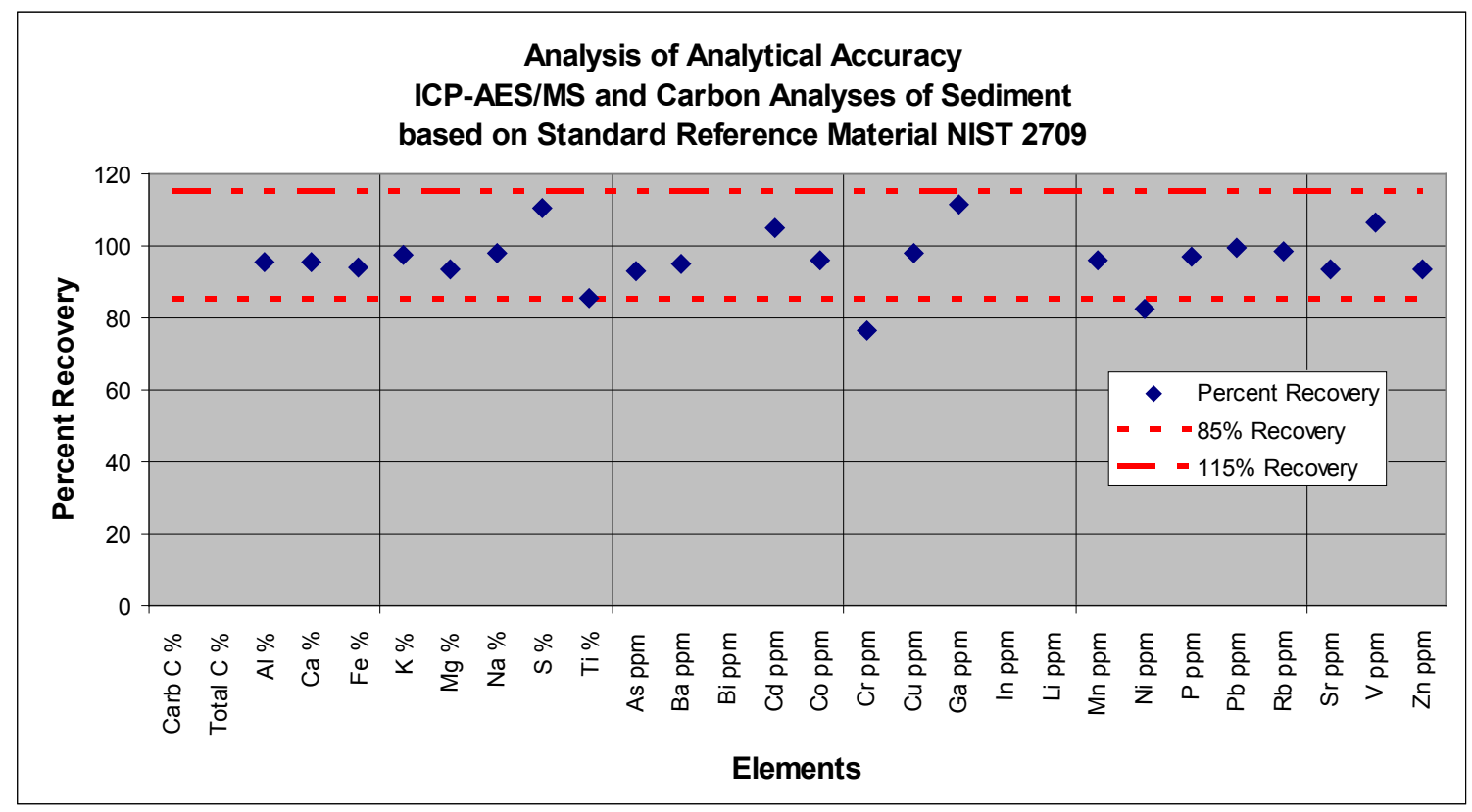

Figure 2-2. Accuracy plot for ICP-AES/MS and carbon analyses for standard reference material NIST 2709. [ICP-AES/MS, inductively coupled plasma-atomic emission spectroscopy/mass spectroscopy; NIST, National Institute of Standards and Technology; \%, percent; ppm, parts per million] 
Table 2-2. Summary statistics for assessing analytical variation and accuracy for the standard reference material NIST 2709 determined after a four-acid total digestion of sediment samples by the ICP-AES-MS package at SGS Minerals and for total and carbonate carbon. (Click to see Excel file.)

[NIST, National Institute of Standards and Technology; ICP-AES/MS, inductively coupled plasma-atomic emission spectroscopy/mass spectroscopy; RL, reporting limit; n, number of analyses of NIST 2709; RSD, relative standard deviation; $\%$, percent; ppm, parts per million; $\mathrm{n} / \mathrm{a}$, not applicable]

\begin{tabular}{llllccccc}
\hline \multicolumn{1}{c}{ Element } & Units & $\mathbf{R L}$ & $\mathbf{n}$ & $\begin{array}{c}\text { Target } \\
\text { value }\end{array}$ & Mean & $\begin{array}{c}\text { Standard } \\
\text { deviation }\end{array}$ & \% RSD & \% Recovery \\
\hline $\mathrm{Al}$ & $\%$ & 0.01 & 6 & 7.50 & 7.16 & 0.12 & 1.74 & 96 \\
$\mathrm{Ca}$ & $\%$ & 0.01 & 6 & 1.89 & 1.81 & 0.01 & 0.81 & 96 \\
$\mathrm{Fe}$ & $\%$ & 0.01 & 6 & 3.50 & 3.29 & 0.07 & 2.25 & 94 \\
$\mathrm{~K}$ & $\%$ & 0.01 & 6 & 2.03 & 1.98 & 0.04 & 2.24 & 97 \\
$\mathrm{Mg}$ & $\%$ & 0.01 & 6 & 1.51 & 1.41 & 0.03 & 1.88 & 94 \\
$\mathrm{Na}$ & $\%$ & 0.01 & 6 & 1.16 & 1.14 & 0.01 & 1.29 & 98 \\
$\mathrm{~S}$ & $\%$ & 0.01 & 6 & 0.062 & 0.10 & 0.00 & 4.15 & 110 \\
$\mathrm{Ti}$ & $\%$ & 0.01 & 6 & 0.34 & 0.29 & 0.01 & 2.58 & 85 \\
$\mathrm{As}$ & $\mathrm{ppm}$ & 1 & 6 & 17.7 & 16.5 & 0.84 & 5.07 & 93 \\
$\mathrm{Ba}$ & $\mathrm{ppm}$ & 5 & 6 & 968 & 921 & 14.1 & 1.5 & 95 \\
$\mathrm{Bi}$ & $\mathrm{ppm}$ & 0.04 & 6 & $\mathrm{n} / \mathrm{a}$ & 0.29 & 0.02 & 5.32 & $\mathrm{n} / \mathrm{a}$ \\
$\mathrm{Cd}$ & $\mathrm{ppm}$ & 0.1 & 6 & 0.38 & 0.40 & 0.00 & 0.00 & 105 \\
$\mathrm{Co}$ & $\mathrm{ppm}$ & 0.1 & 6 & 13.4 & 12.8 & 0.38 & 2.9 & 96 \\
$\mathrm{Cr}$ & $\mathrm{ppm}$ & 1 & 6 & 130 & 99.3 & 3.50 & 3.53 & 76 \\
$\mathrm{Cu}$ & $\mathrm{ppm}$ & 0.5 & 6 & 34.6 & 33.8 & 2.42 & 7.2 & 98 \\
$\mathrm{Ga}$ & $\mathrm{ppm}$ & 0.05 & 6 & 14 & 15.6 & 0.57 & 3.7 & 111 \\
$\mathrm{In}$ & $\mathrm{ppm}$ & 0.02 & 6 & $\mathrm{n} / \mathrm{a}$ & 0.05 & 0.00 & 7.9 & $\mathrm{n} / \mathrm{a}$ \\
$\mathrm{Li}$ & $\mathrm{ppm}$ & 1 & 6 & $\mathrm{n} / \mathrm{a}$ & 51 & 1.41 & 2.8 & $\mathrm{n} / \mathrm{a}$ \\
$\mathrm{Mn}$ & $\mathrm{ppm}$ & 5 & 6 & 538 & 516 & 13.3 & 2.6 & 96 \\
$\mathrm{Ni}$ & $\mathrm{ppm}$ & 0.5 & 6 & 88.0 & 72.5 & 1.86 & 2.6 & 82 \\
$\mathrm{P}$ & $\mathrm{ppm}$ & 50 & 6 & 0.062 & 602 & 29.3 & 4.9 & 99 \\
$\mathrm{~Pb}$ & $\mathrm{ppm}$ & 0.5 & 6 & 18.9 & 18.8 & 1.67 & 8.9 & 100 \\
$\mathrm{Rb}$ & $\mathrm{ppm}$ & 0.2 & 6 & $\mathrm{n} / \mathrm{a}$ & 94.4 & 3.16 & 3.3 & $\mathrm{n} / \mathrm{a}$ \\
$\mathrm{Sr}$ & $\mathrm{ppm}$ & 0.5 & 6 & 231 & 216 & 2.07 & 1.0 & 94 \\
$\mathrm{~V}$ & $\mathrm{ppm}$ & 1 & 6 & 112 & 120 & 2.51 & 2.1 & 107 \\
$\mathrm{Zn}$ & $\mathrm{ppm}$ & 1 & 6 & 106 & 99.3 & 3.50 & 3.5 & 94 \\
$\mathrm{Total} \mathrm{C}$ & $\%$ & 0.01 & 6 & $\mathrm{n} / \mathrm{a}$ & 1.16 & 0.03 & 2.8 & $\mathrm{n} / \mathrm{a}$ \\
$\mathrm{Carbonate} \mathrm{C}$ & $\%$ & 0.003 & 6 & $\mathrm{n} / \mathrm{a}$ & 0.25 & 0.00 & 1.62 & $\mathrm{n} / \mathrm{a}$ \\
\hline & & & & & & & & \\
\hline
\end{tabular}


The SRM NIST 2711 was analyzed six times along with the samples. Table $2-3$ gives the percent RSD and percent recovery results for this standard, and figure $2-3$ shows graphically the accuracy plot. Those elements that show " $\mathrm{n} / \mathrm{a}$ " in table 2-3 or have no symbol plotted on figure 2-3 do not have a certified value for comparison. All plotted elements except chromium and nickel fall within \pm 15 percent of the target values. The chromium recovery is low, 79 percent, due to the difficulty of the four-acid digestion to dissolve the refractory mineral phase in which chromium resides.

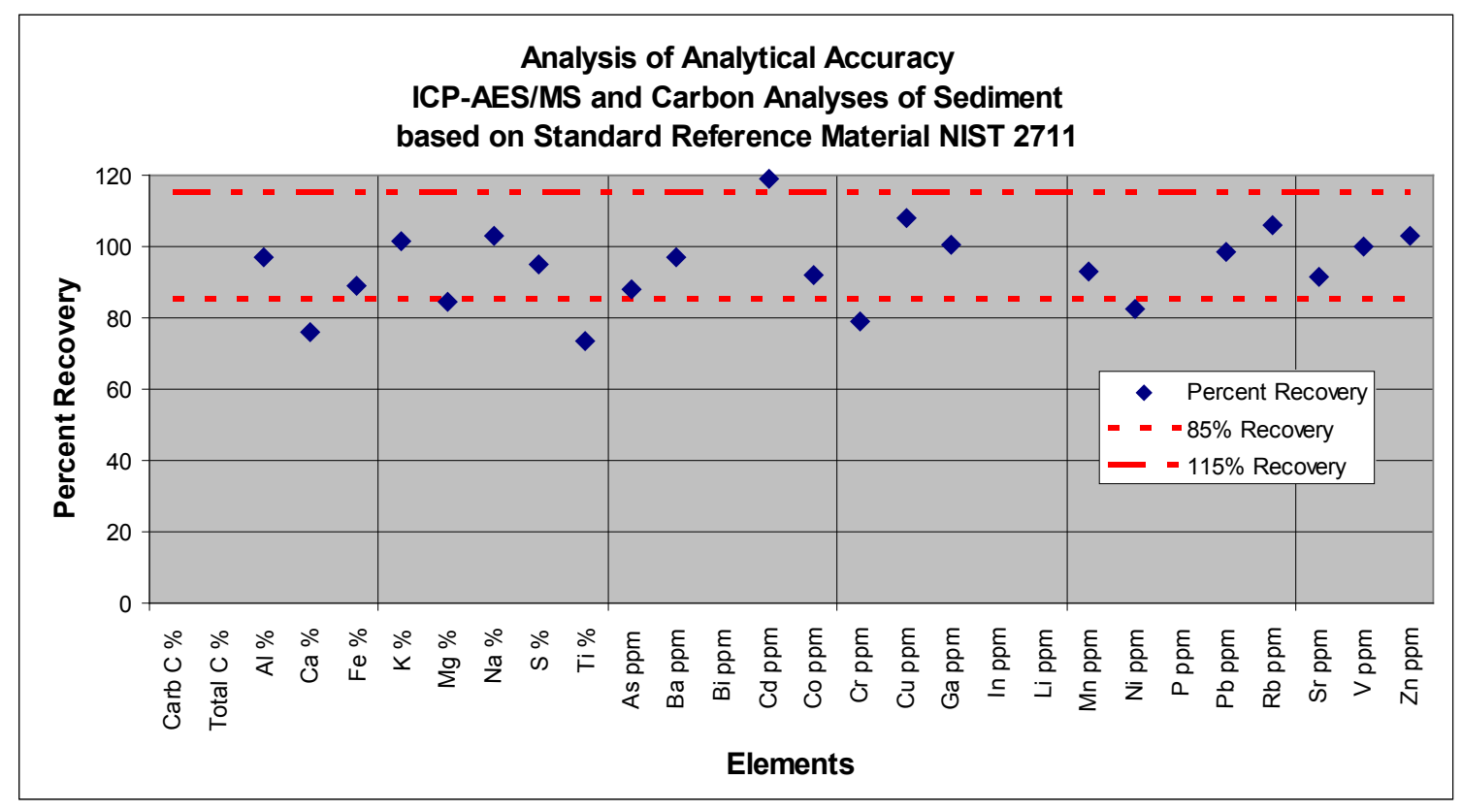

Figure 2-3. Accuracy plot for ICP-AES/MS and carbon analyses for standard reference material NIST 2711. [ICP-AES/MS, inductively coupled plasma-atomic emission spectroscopy/mass spectroscopy; NIST, National Institute of Standards and Technology; \%, percent; ppm, parts per million] 
Table 2-3. Summary statistics for assessing analytical variation and accuracy for the standard reference material NIST 2711 determined after a four-acid total digestion of sediment samples by the ICP-AES/MS package at SGS Minerals and for total and carbonate carbon. (Click to see Excel file.)

[NIST, National Institute of Standards and Technology; ICP-AES/MS, inductively coupled plasma-atomic emission spectroscopy/mass spectroscopy; RL, reporting limit ; n, number of analyses of NIST 2711; RSD, relative standard deviation; \%, percent; ppm, parts per million; n/a, not applicable]

\begin{tabular}{|c|c|c|c|c|c|c|c|c|}
\hline Element & Units & RL & $n$ & $\begin{array}{l}\text { Target } \\
\text { value }\end{array}$ & Mean & $\begin{array}{l}\text { Standard } \\
\text { deviation }\end{array}$ & $\%$ RSD & $\%$ Recovery \\
\hline $\mathrm{Al}$ & $\%$ & 0.01 & 6 & 6.53 & 6.34 & 0.18 & 2.87 & 97 \\
\hline $\mathrm{Ca}$ & $\%$ & 0.01 & 6 & 2.88 & 2.19 & 0.06 & 2.64 & 76 \\
\hline $\mathrm{Fe}$ & $\%$ & 0.01 & 6 & 2.89 & 2.57 & 0.06 & 2.43 & 89 \\
\hline $\mathrm{K}$ & $\%$ & 0.01 & 6 & 2.45 & 2.49 & 0.08 & 3.13 & 102 \\
\hline $\mathrm{Mg}$ & $\%$ & 0.01 & 6 & 1.05 & 0.89 & 0.03 & 3.26 & 84 \\
\hline $\mathrm{Na}$ & $\%$ & 0.01 & 6 & 1.14 & 1.17 & 0.03 & 2.61 & 103 \\
\hline S & $\%$ & 0.01 & 6 & 0.086 & 0.04 & 0.00 & 0.00 & 46 \\
\hline $\mathrm{Ti}$ & $\%$ & 0.01 & 6 & 0.306 & 0.23 & 0.01 & 3.72 & 74 \\
\hline As & ppm & 1 & 6 & 105 & 92.3 & 1.21 & 1.31 & 88 \\
\hline $\mathrm{Ba}$ & ppm & 5 & 6 & 726 & 703 & 7.52 & 1.07 & 97 \\
\hline $\mathrm{Bi}$ & ppm & 0.04 & 6 & $\mathrm{n} / \mathrm{a}$ & 2.72 & 0.04 & 1.46 & $\mathrm{n} / \mathrm{a}$ \\
\hline $\mathrm{Cd}$ & ppm & 0.1 & 6 & 41.7 & 49.7 & 2.51 & 5.06 & 119 \\
\hline $\mathrm{Co}$ & ppm & 0.1 & 6 & 10 & 9.18 & 0.32 & 3.47 & 92 \\
\hline $\mathrm{Cr}$ & ppm & 1 & 6 & 47 & 37.2 & 2.71 & 7.30 & 79 \\
\hline $\mathrm{Cu}$ & ppm & 0.5 & 6 & 114 & 123 & 5.38 & 4.37 & 108 \\
\hline $\mathrm{Ga}$ & ppm & 0.05 & 6 & 15 & 15.1 & 0.79 & 5.25 & 101 \\
\hline In & ppm & 0.02 & 6 & $\mathrm{n} / \mathrm{a}$ & 1.13 & 0.04 & 3.90 & $\mathrm{n} / \mathrm{a}$ \\
\hline $\mathrm{Li}$ & ppm & 1 & 6 & $\mathrm{n} / \mathrm{a}$ & 24.2 & 0.75 & 3.11 & $\mathrm{n} / \mathrm{a}$ \\
\hline $\mathrm{Mn}$ & ppm & 5 & 6 & 638 & 592 & 16.4 & 2.77 & 93 \\
\hline $\mathrm{Ni}$ & ppm & 0.5 & 6 & 20.6 & 17.0 & 0.60 & 3.56 & 82 \\
\hline $\mathrm{P}$ & ppm & 50 & 6 & 860 & 793 & 10.3 & 1.30 & 92 \\
\hline $\mathrm{Pb}$ & ppm & 0.5 & 6 & 1,162 & 1,142 & 61.8 & 5.41 & 98 \\
\hline $\mathrm{Rb}$ & ppm & 0.2 & 6 & $\mathrm{n} / \mathrm{a}$ & 116 & 4.63 & 3.98 & $\mathrm{n} / \mathrm{a}$ \\
\hline $\mathrm{Sr}$ & ppm & 0.5 & 6 & 245 & 225 & 3.27 & 1.46 & 92 \\
\hline $\mathrm{V}$ & ppm & 1 & 6 & 81.6 & 81.5 & 3.02 & 3.70 & 100 \\
\hline $\mathrm{Zn}$ & ppm & 1 & 6 & 350 & 361 & 12.3 & 3.42 & 103 \\
\hline Total C & $\%$ & 0.01 & 6 & $\mathrm{n} / \mathrm{a}$ & 1.55 & 0.06 & 3.81 & $\mathrm{n} / \mathrm{a}$ \\
\hline Carbonate C & $\%$ & 0.003 & 6 & $\mathrm{n} / \mathrm{a}$ & 0.34 & 0.01 & 1.59 & $\mathrm{n} / \mathrm{a}$ \\
\hline
\end{tabular}


The SRM NIST 8704 was analyzed six times along with the samples. Table $2-4$ gives the percent RSD and percent recovery results for this standard, and figure 2-4 shows graphically the accuracy plot. Those elements that show " $\mathrm{n} / \mathrm{a}$ " in table $2-4$ or have no symbol plotted on figure $2-4$ do not have a certified value for comparison. All plotted elements except titanium, arsenic, and chromium fall within \pm 15 percent of the target values. The recovery for titanium was only 43 percent, and the recovery for chromium was 81 percent; both of these elements can occur in mineral phases that are difficult to fully dissolve by the four-acid digestion procedure. The arsenic recovery, 74 percent, is related to the low precision and accuracy at low analytical levels (arsenic is present at less than 20 times the method reporting limit).

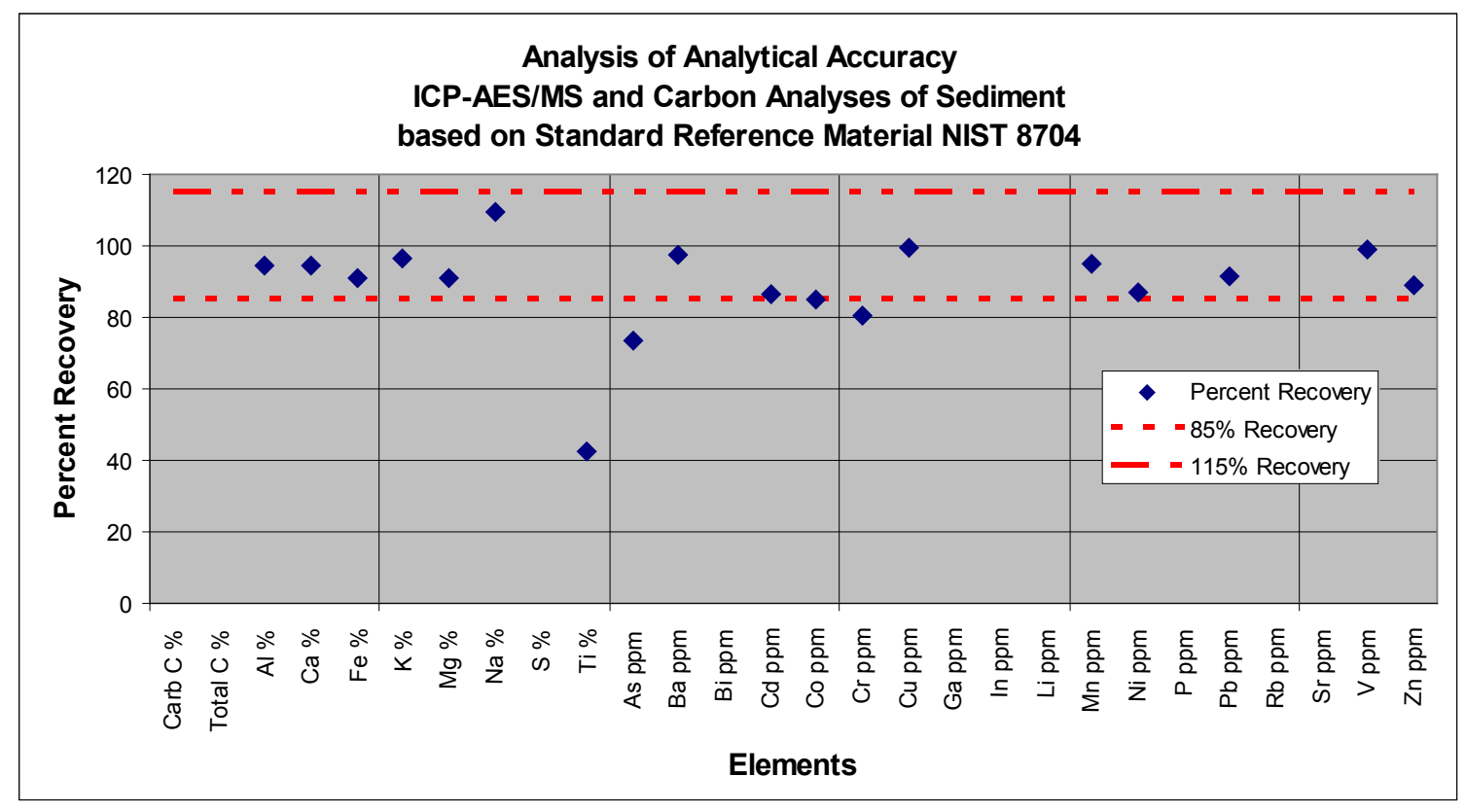

Figure 2-4. Accuracy plot for ICP-AES/MS and carbon analyses for standard reference material NIST 8704. [ICP-AES/MS, inductively coupled plasma-atomic emission spectroscopy/mass spectroscopy; NIST, National Institute of Standards and Technology; \%, percent; ppm, parts per million] 
Table 2-4. Summary statistics for assessing analytical variation and accuracy for the standard reference material NIST 8704 determined after a four-acid total digestion of sediment samples by the ICP-AES/MS package at SGS Minerals and for total and carbonate carbon. (Click to see Excel file.)

[NIST, National Institute of Standards and Technology; ICP-AES/MS, inductively coupled plasma-atomic emission spectroscopy/mass spectroscopy; RL, reporting limit; n, number of analyses of NIST 8704; RSD, relative standard deviation; $\%$, percent; ppm, parts per million; $\mathrm{n} / \mathrm{a}$, not applicable]

\begin{tabular}{llllcccrc}
\hline \multicolumn{1}{c}{ Element } & Units & $\mathbf{R L}$ & $\mathbf{n}$ & $\begin{array}{c}\text { Target } \\
\text { value }\end{array}$ & Mean & $\begin{array}{c}\text { Standard } \\
\text { deviation }\end{array}$ & \% RSD & \% Recovery \\
\hline $\mathrm{Al}$ & $\%$ & 0.01 & 6 & 6.1 & 5.77 & 0.09 & 1.6 & 95 \\
$\mathrm{Ca}$ & $\%$ & 0.01 & 6 & 2.64 & 2.49 & 0.05 & 2.0 & 94 \\
$\mathrm{Fe}$ & $\%$ & 0.01 & 6 & 3.97 & 3.61 & 0.07 & 1.9 & 91 \\
$\mathrm{~K}$ & $\%$ & 0.01 & 6 & 2 & 1.93 & 0.04 & 2.2 & 97 \\
$\mathrm{Mg}$ & $\%$ & 0.01 & 6 & 1.20 & 1.09 & 0.02 & 2.1 & 91 \\
$\mathrm{Na}$ & $\%$ & 0.01 & 6 & 0.553 & 0.61 & 0.01 & 1.7 & 109 \\
$\mathrm{~S}$ & $\%$ & 0.01 & 6 & $\mathrm{n} / \mathrm{a}$ & 0.37 & 0.02 & 4.3 & $\mathrm{n} / \mathrm{a}$ \\
$\mathrm{Ti}$ & $\%$ & 0.01 & 6 & 0.457 & 0.20 & 0.02 & 7.8 & 43 \\
$\mathrm{As}$ & $\mathrm{ppm}$ & 1 & 6 & 17.0 & 12.5 & 2.74 & 21.9 & 74 \\
$\mathrm{Ba}$ & $\mathrm{ppm}$ & 5 & 6 & 413 & 403 & 9.67 & 2.4 & 97 \\
$\mathrm{Bi}$ & $\mathrm{ppm}$ & 0.04 & 6 & $\mathrm{n} / \mathrm{a}$ & 1.92 & 0.53 & 27.7 & $\mathrm{n} / \mathrm{a}$ \\
$\mathrm{Cd}$ & $\mathrm{ppm}$ & 0.1 & 6 & 2.94 & 2.98 & 0.26 & 8.7 & 101 \\
$\mathrm{Co}$ & $\mathrm{ppm}$ & 0.1 & 6 & 13.6 & 2.55 & 1.08 & 42.3 & 85 \\
$\mathrm{Cr}$ & $\mathrm{ppm}$ & 1 & 6 & 122 & 11.6 & 3.18 & 27.5 & 81 \\
$\mathrm{Cu}$ & $\mathrm{ppm}$ & 0.5 & 6 & 87 & 98.5 & 2.51 & 2.5 & 100 \\
$\mathrm{Ga}$ & $\mathrm{ppm}$ & 0.05 & 6 & $\mathrm{n} / \mathrm{a}$ & 86.8 & 5.88 & 6.8 & $\mathrm{n} / \mathrm{a}$ \\
$\mathrm{In}$ & $\mathrm{ppm}$ & 0.02 & 6 & $\mathrm{n} / \mathrm{a}$ & 13.0 & 2.53 & 19.5 & $\mathrm{n} / \mathrm{a}$ \\
$\mathrm{Li}$ & $\mathrm{ppm}$ & 1 & 6 & $\mathrm{n} / \mathrm{a}$ & 0.08 & 0.03 & 31.9 & $\mathrm{n} / \mathrm{a}$ \\
$\mathrm{Mn}$ & $\mathrm{ppm}$ & 5 & 6 & 544 & 41.7 & 0.82 & 2.0 & 95 \\
$\mathrm{Ni}$ & $\mathrm{ppm}$ & 0.5 & 6 & 42.9 & 517 & 11.3 & 2.2 & 87 \\
$\mathrm{P}$ & $\mathrm{ppm}$ & 50 & 6 & $\mathrm{n} / \mathrm{a}$ & 37.3 & 1.82 & 4.9 & $\mathrm{n} / \mathrm{a}$ \\
$\mathrm{Pb}$ & $\mathrm{ppm}$ & 0.5 & 6 & 150 & 923 & 25.8 & 2.8 & 91 \\
$\mathrm{Rb}$ & $\mathrm{ppm}$ & 0.2 & 6 & $\mathrm{n} / \mathrm{a}$ & 137 & 9.19 & 6.7 & $\mathrm{n} / \mathrm{a}$ \\
$\mathrm{Sr}$ & $\mathrm{ppm}$ & 0.5 & 6 & $\mathrm{n} / \mathrm{a}$ & 92.9 & 11.2 & 12.0 & $\mathrm{n} / \mathrm{a}$ \\
$\mathrm{V}$ & $\mathrm{ppm}$ & 1 & 6 & 94.6 & 127 & 1.76 & 1.4 & 99 \\
$\mathrm{Zn}$ & $\mathrm{ppm}$ & 1 & 6 & 408 & 93.8 & 1.83 & 2.0 & 89 \\
$\mathrm{Total} \mathrm{C}$ & $\%$ & 0.01 & 0 & $\mathrm{n} / \mathrm{a}$ & $\mathrm{n} / \mathrm{a}$ & $\mathrm{n} / \mathrm{a}$ & $\mathrm{n} / \mathrm{a}$ & $\mathrm{n} / \mathrm{a}$ \\
$\mathrm{Carbonate} \mathrm{C}$ & $\%$ & 0.003 & 0 & $\mathrm{n} / \mathrm{a}$ & $\mathrm{n} / \mathrm{a}$ & $\mathrm{n} / \mathrm{a}$ & $\mathrm{n} / \mathrm{a}$ & $\mathrm{n} / \mathrm{a}$ \\
\hline & & & & & & & & \\
\hline
\end{tabular}




\section{SRM CCRMP SO-3}

The SRM CCRMP SO-3 was analyzed eight times along with the samples. Table 2-5 gives the percent RSD and percent recovery results for this standard, and figure 2-5 shows graphically the accuracy plot. Those elements that show " $\mathrm{n} / \mathrm{a}$ " in table $2-5$ or have no symbol plotted on figure $2-5$ do not have a certified value for comparison. All plotted elements except titanium, copper, and nickel fall within \pm 15 percent of the target values. The titanium recovery was 80 percent, probably due to difficulties in obtaining a complete decomposition of refractory titanium phases using the four-acid digestion. The low accuracy estimates for copper and nickel (82 and 72 percent, respectively) may be due to those elements' concentrations being near instrumental reporting limits.

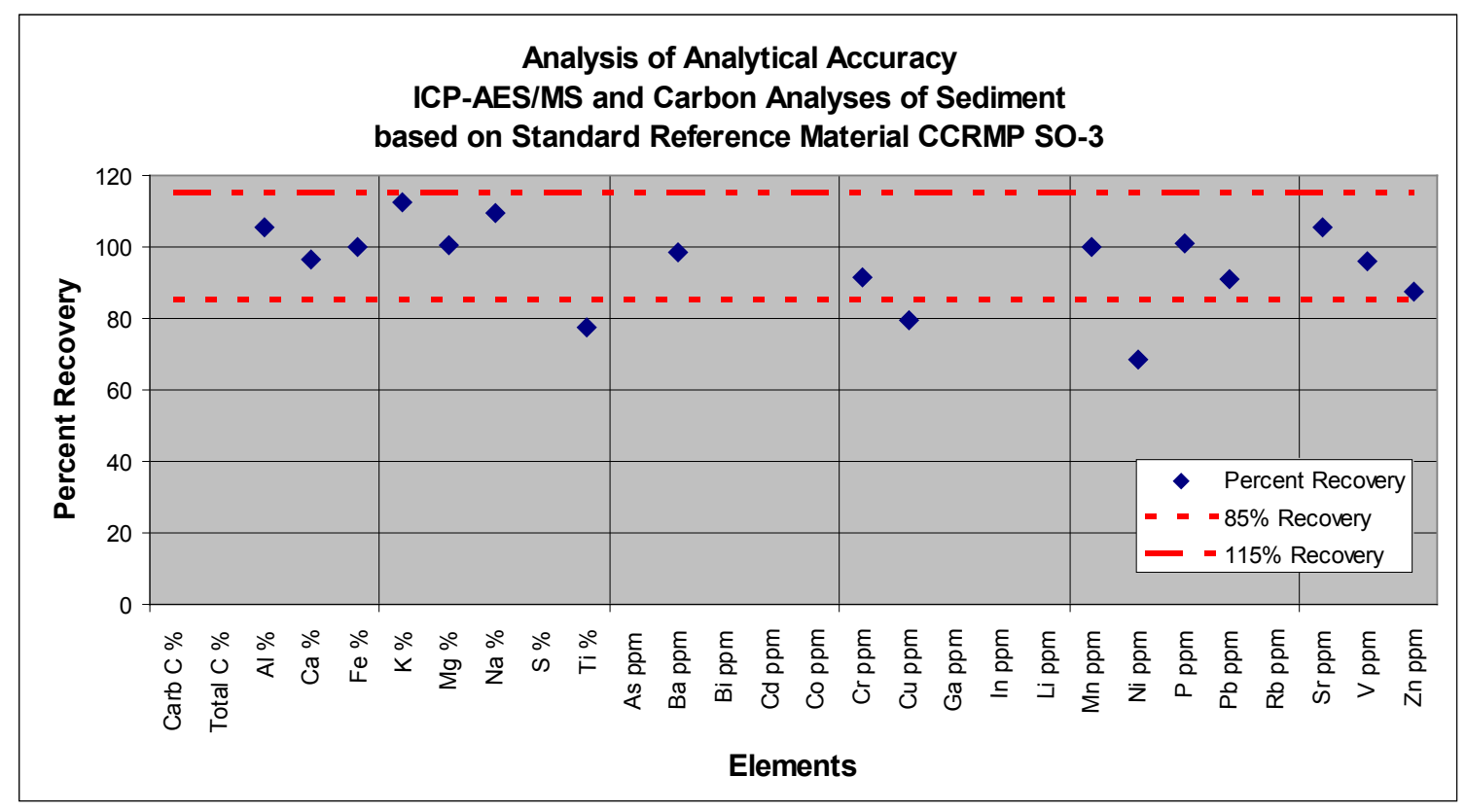

Figure 2-5. Accuracy plot for ICP-AES/MS and carbon analyses for standard reference material CCRMP SO-3. [ICP-AES/MS, inductively coupled plasma-atomic emission spectroscopy/mass spectroscopy; CCRMP, Canadian Certified Reference Materials Project; \%, percent; ppm, parts per million] 
Table 2-5. Summary statistics for assessing analytical variation and accuracy for the standard reference material CCRMP SO-3 determined after a four-acid total digestion of sediment samples by the ICP-AES/MS package at SGS Minerals and for total and carbonate carbon. (Click to see Excel file.)

[CCRMP, Canadian Certified Reference Materials Project; ICP-AES/MS, inductively coupled plasma-atomic emission spectroscopy/mass spectroscopy; RL, reporting limit; n, number of analyses of CCRMP SO-3; RSD, relative standard deviation; \%, percent; ppm, parts per million; $\mathrm{n} / \mathrm{a}$, not applicable]

\begin{tabular}{llllccccr}
\hline \multicolumn{1}{c}{ Element } & Units & $\mathbf{R L}$ & $\mathbf{n}$ & $\begin{array}{c}\text { Target } \\
\text { value }\end{array}$ & Mean & $\begin{array}{c}\text { Standard } \\
\text { deviation }\end{array}$ & \% RSD & \% Recovery \\
\hline $\mathrm{Al}$ & $\%$ & 0.01 & 8 & 3.06 & 3.21 & 0.06 & 1.9 & 105 \\
$\mathrm{Ca}$ & $\%$ & 0.01 & 8 & 14.6 & 14.1 & 0.32 & 2.29 & 97 \\
$\mathrm{Fe}$ & $\%$ & 0.01 & 8 & 1.51 & 1.51 & 0.02 & 1.12 & 100 \\
$\mathrm{~K}$ & $\%$ & 0.01 & 8 & 1.16 & 1.29 & 0.05 & 4.14 & 111 \\
$\mathrm{Mg}$ & $\%$ & 0.01 & 8 & 4.98 & 5.00 & 0.06 & 1.19 & 100 \\
$\mathrm{Na}$ & $\%$ & 0.01 & 8 & 0.74 & 0.80 & 0.02 & 3.02 & 108 \\
$\mathrm{~S}$ & $\%$ & 0.01 & 8 & $\mathrm{n} / \mathrm{a}$ & 0.02 & 0.00 & 0.00 & $\mathrm{n} / \mathrm{a}$ \\
$\mathrm{Ti}$ & $\%$ & 0.01 & 8 & 0.2 & 0.16 & 0.02 & 9.88 & 80 \\
$\mathrm{As}$ & $\mathrm{ppm}$ & 1 & 8 & $\mathrm{n} / \mathrm{a}$ & 2.00 & 0.58 & 28.9 & $\mathrm{n} / \mathrm{a}$ \\
$\mathrm{Ba}$ & $\mathrm{ppm}$ & 5 & 8 & 296 & 292 & 5.46 & 1.87 & 99 \\
$\mathrm{Bi}$ & $\mathrm{ppm}$ & 0.04 & 8 & $\mathrm{n} / \mathrm{a}$ & 0.08 & 0.01 & 15.5 & $\mathrm{n} / \mathrm{a}$ \\
$\mathrm{Cd}$ & $\mathrm{ppm}$ & 0.1 & 8 & $\mathrm{n} / \mathrm{a}$ & 0.14 & 0.05 & 37.6 & $\mathrm{n} / \mathrm{a}$ \\
$\mathrm{Co}$ & $\mathrm{ppm}$ & 0.1 & 8 & $\mathrm{n} / \mathrm{a}$ & 5.31 & 0.30 & 5.64 & $\mathrm{n} / \mathrm{a}$ \\
$\mathrm{Cr}$ & $\mathrm{ppm}$ & 1 & 8 & 26 & 24.0 & 2.96 & 12.3 & 92 \\
$\mathrm{Cu}$ & $\mathrm{ppm}$ & 0.5 & 8 & 17 & 13.9 & 2.29 & 16.5 & 82 \\
$\mathrm{Ga}$ & $\mathrm{ppm}$ & 0.05 & 8 & $\mathrm{n} / \mathrm{a}$ & 6.90 & 0.35 & 5.12 & $\mathrm{n} / \mathrm{a}$ \\
$\mathrm{In}$ & $\mathrm{ppm}$ & 0.02 & 8 & $\mathrm{n} / \mathrm{a}$ & 0.03 & 0.00 & 0.00 & $\mathrm{n} / \mathrm{a}$ \\
$\mathrm{Li}$ & $\mathrm{ppm}$ & 1 & 8 & $\mathrm{n} / \mathrm{a}$ & 12.6 & 0.52 & 4.10 & $\mathrm{n} / \mathrm{a}$ \\
$\mathrm{Mn}$ & $\mathrm{ppm}$ & 5 & 8 & 520 & 520 & 5.87 & 1.13 & 100 \\
$\mathrm{Ni}$ & $\mathrm{ppm}$ & 0.5 & 8 & 16 & 11.5 & 1.87 & 16.3 & 72 \\
$\mathrm{P}$ & $\mathrm{ppm}$ & 50 & 8 & 480 & 484 & 11.3 & 2.33 & 101 \\
$\mathrm{~Pb}$ & $\mathrm{ppm}$ & 0.5 & 8 & 14 & 12.9 & 0.62 & 4.85 & 92 \\
$\mathrm{Rb}$ & $\mathrm{ppm}$ & 0.2 & 8 & $\mathrm{n} / \mathrm{a}$ & 37.6 & 1.40 & 3.72 & $\mathrm{n} / \mathrm{a}$ \\
$\mathrm{Sr}$ & $\mathrm{ppm}$ & 0.5 & 8 & 217 & 227 & 4.66 & 2.05 & 105 \\
$\mathrm{~V}$ & $\mathrm{ppm}$ & 1 & 8 & 38 & 36.7 & 0.71 & 1.93 & 96 \\
$\mathrm{Zn}$ & $\mathrm{ppm}$ & 1 & 8 & 52 & 46.1 & 3.41 & 7.39 & 89 \\
$\mathrm{Total} \mathrm{C}$ & $\%$ & 0.01 & 8 & $\mathrm{n} / \mathrm{a}$ & 6.66 & 0.11 & 1.60 & $\mathrm{n} / \mathrm{a}$ \\
$\mathrm{Carbonate} \mathrm{C}$ & $\%$ & 0.003 & 0 & $\mathrm{n} / \mathrm{a}$ & $\mathrm{n} / \mathrm{a}$ & $\mathrm{n} / \mathrm{a}$ & $\mathrm{n} / \mathrm{a}$ & $\mathrm{n} / \mathrm{a}$ \\
\hline & & & & & & & &
\end{tabular}




\section{SRM USGS DGPM-1}

The SRM USGS DGPM-1 was analyzed four times along with the samples. Table $2-6$ gives the percent RSD and percent recovery results for this standard, and figure 2-6 shows graphically the accuracy plot. Those elements that show " $\mathrm{n} / \mathrm{a}$ " in table $2-6$ or have no symbol plotted on figure 2-6 do not have a certified value for comparison. All plotted elements except cadmium fall within \pm 15 percent of the target values. The cadmium recovery, 83 percent, is quite acceptable given that the concentration is only three times the analytical reporting limit.

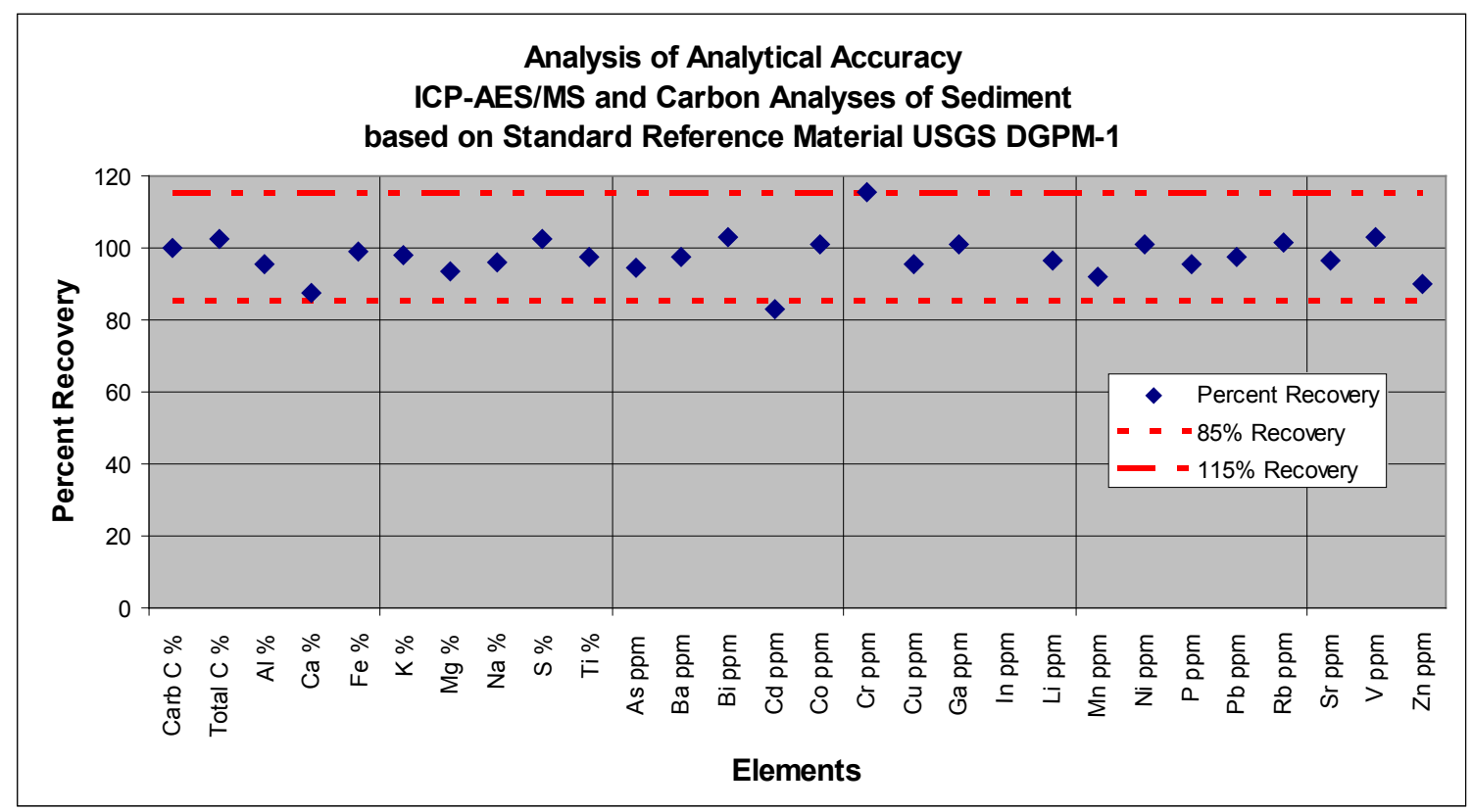

Figure 2-6. Accuracy plot for ICP-AES/MS and carbon analyses for standard reference material USGS DGPM-1. [ICP-AES/MS, inductively coupled plasma-atomic emission spectroscopy/mass spectroscopy; USGS, U.S. Geological Survey; DGPM, disseminated gold ore, Pinson Mine, Nev.; $\%$, percent; ppm, parts per million] 
Table 2-6. Summary statistics for assessing analytical variation and accuracy for the standard reference material USGS DGPM-1 determined after a four-acid total digestion of sediment samples by the ICP-AES/MS package at SGS Minerals and for total and carbonate carbon. (Click to see Excel file.)

[USGS, U.S. Geological Survey; DGPM, disseminated gold ore, Pinson Mine, Nev.; ICP-AES/MS, inductively coupled plasma-atomic emission spectroscopy/mass spectroscopy; RL, reporting limit; n, number of analyses of DGPM-1; RSD, relative standard deviation; \%, percent; ppm, parts per million; n/a, not applicable]

\begin{tabular}{llllccccr}
\hline \multicolumn{1}{c}{ Element } & Units & $\mathbf{R L}$ & $\mathbf{n}$ & $\begin{array}{l}\text { Target } \\
\text { value }\end{array}$ & Mean & $\begin{array}{c}\text { Standard } \\
\text { deviation }\end{array}$ & \% RSD & \% Recovery \\
\hline $\mathrm{Al}$ & $\%$ & 0.01 & 4 & 5.06 & 4.88 & 0.17 & 3.4 & 96 \\
$\mathrm{Ca}$ & $\%$ & 0.01 & 4 & 0.157 & 0.14 & 0.01 & 3.54 & 90 \\
$\mathrm{Fe}$ & $\%$ & 0.01 & 4 & 1.34 & 1.33 & 0.04 & 3.04 & 99 \\
$\mathrm{~K}$ & $\%$ & 0.01 & 4 & 2.27 & 2.24 & 0.07 & 2.99 & 99 \\
$\mathrm{Mg}$ & $\%$ & 0.01 & 4 & 0.337 & 0.32 & 0.01 & 1.81 & 95 \\
$\mathrm{Na}$ & $\%$ & 0.01 & 4 & 0.06 & 0.06 & 0.01 & 8.70 & 96 \\
$\mathrm{~S}$ & $\%$ & 0.01 & 4 & 0.363 & 0.37 & 0.01 & 2.57 & 103 \\
$\mathrm{Ti}$ & $\%$ & 0.01 & 4 & 0.266 & 0.26 & 0.01 & 3.14 & 98 \\
$\mathrm{As}$ & $\mathrm{ppm}$ & 1 & 4 & 180 & 172 & 1.29 & 0.75 & 96 \\
$\mathrm{Ba}$ & $\mathrm{ppm}$ & 5 & 4 & 1,326 & 1,293 & 20.6 & 1.60 & 97 \\
$\mathrm{Bi}$ & $\mathrm{ppm}$ & 0.04 & 4 & 0.114 & 0.12 & 0.02 & 18.9 & 103 \\
$\mathrm{Cd}$ & $\mathrm{ppm}$ & 0.1 & 4 & 0.33 & 0.28 & 0.05 & 18.2 & 83 \\
$\mathrm{Co}$ & $\mathrm{ppm}$ & 0.1 & 4 & 1.36 & 1.38 & 0.15 & 10.9 & 101 \\
$\mathrm{Cr}$ & $\mathrm{ppm}$ & 1 & 4 & 97 & 112 & 17.05 & 15.2 & 115 \\
$\mathrm{Cu}$ & $\mathrm{ppm}$ & 0.5 & 4 & 13.7 & 13.1 & 1.71 & 13.0 & 95 \\
$\mathrm{Ga}$ & $\mathrm{ppm}$ & 0.05 & 4 & 10.8 & 10.9 & 0.46 & 4.25 & 101 \\
$\mathrm{In}$ & $\mathrm{ppm}$ & 0.02 & 4 & $\mathrm{n} / \mathrm{a}$ & $<0.02$ & $\mathrm{n} / \mathrm{a}$ & $\mathrm{n} / \mathrm{a}$ & $\mathrm{n} / \mathrm{a}$ \\
$\mathrm{Li}$ & $\mathrm{ppm}$ & 1 & 4 & 39.6 & 38.2 & 0.96 & 2.50 & 97 \\
$\mathrm{Mn}$ & $\mathrm{ppm}$ & 5 & 4 & 28 & 25.7 & 2.87 & 11.2 & 92 \\
$\mathrm{Ni}$ & $\mathrm{ppm}$ & 0.5 & 4 & 11.4 & 11.5 & 3.56 & 31.0 & 101 \\
$\mathrm{P}$ & $\mathrm{ppm}$ & 50 & 4 & 418 & 400 & 8.16 & 2.04 & 96 \\
$\mathrm{~Pb}$ & $\mathrm{ppm}$ & 0.5 & 4 & 9.8 & 9.58 & 0.66 & 6.84 & 98 \\
$\mathrm{Rb}$ & $\mathrm{ppm}$ & 0.2 & 4 & 90 & 91.6 & 4.77 & 5.21 & 102 \\
$\mathrm{Sr}$ & $\mathrm{ppm}$ & 0.5 & 4 & 91.5 & 88.2 & 1.43 & 1.63 & 96 \\
$\mathrm{~V}$ & $\mathrm{ppm}$ & 1 & 4 & 106 & 109 & 2.16 & 1.98 & 103 \\
$\mathrm{Zn}$ & $\mathrm{ppm}$ & 1 & 4 & 24.4 & 22.0 & 1.15 & 5.25 & 90 \\
$\mathrm{Total} \mathrm{C}$ & $\%$ & 0.01 & 4 & 0.10 & 0.10 & 0.01 & 9.34 & 103 \\
$\mathrm{Carbonate} \mathrm{C}$ & $\%$ & 0.003 & 3 & 0.01 & 0.01 & 0.00 & 0.0 & 100 \\
\hline & & & & & & & &
\end{tabular}




\section{Reference Material USGS GSP-QC}

In contrast to the first five SRMs discussed above, the reference material USGS GSP-QC is not certified nor used outside of the U.S. Geological Survey. It is a material similar to the certified SRM GSP-1 (Silver Plume Granite) but was developed at a later time, and so it is slightly different in elemental concentrations. This material was developed in-house at the Denver USGS laboratories for inclusion with samples sent to the SGS Minerals laboratory. During the period of September 2004 to November 2008, this material was analyzed 360 times by the contract laboratory for the ICP-AES/MS package as blind samples and 120 times for carbon. The results were compiled, and the means derived were used as target values for the accuracy assessments of this material submitted in this report. As a consequence, target values are available for all elements in the ICP-AES/MS package and for total and carbonate carbon.

The noncertified USGS reference material GSP-QC was analyzed five times along with the study samples. Table 2-7 gives the percent RSD and percent recovery results for this standard, and figure 2-7 shows graphically the accuracy plot. The only element that plotted outside of the 15-percent window was nickel at 82 percent, probably due to its low concentration.

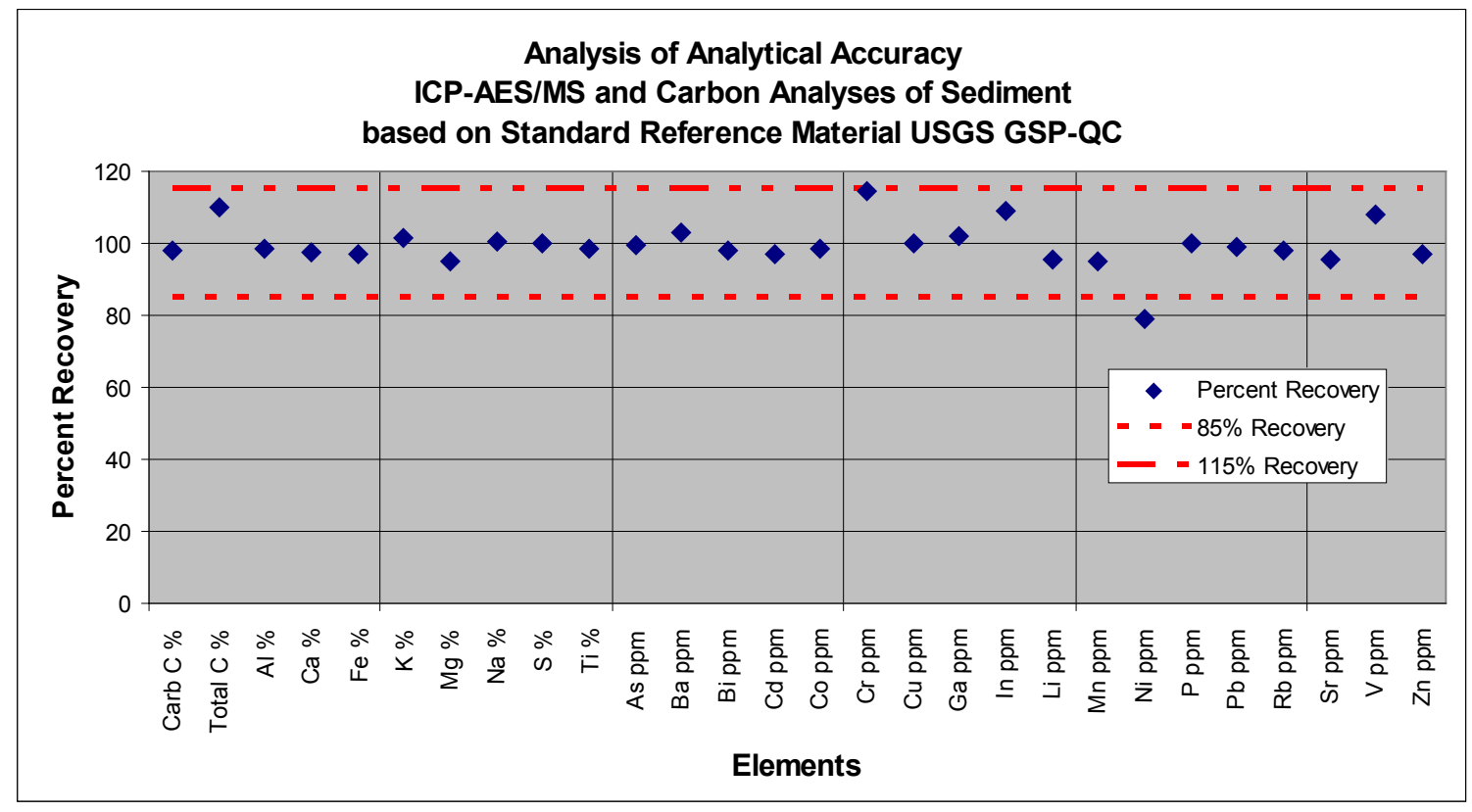

Figure 2-7. Accuracy plot for ICP-AES/MS and carbon analyses for reference material USGS GSP-QC. [ICP-AES/MS, inductively coupled plasma-atomic emission spectroscopy/mass spectroscopy; USGS, U.S. Geological Survey; GSP-QC, granodiorite, Silver Plume, Colo.; \%, percent; ppm, parts per million] 
Table 2-7. Summary statistics for assessing analytical variation and accuracy for the reference material USGS GSP-QC determined after a four-acid total digestion of sediment samples by the ICP-AES/MS package at SGS Minerals and for total and carbonate carbon. (Click to see Excel file.)

[USGS; U.S. Geological Survey; GSP-QC, granodiorite, Silver Plume, Colo.; ICP-AES/MS, inductively coupled plasmaatomic emission spectroscopy/mass spectroscopy; RL, reporting limit; n, number of analyses of GSP-QC; RSD, relative standard deviation; \%, percent; ppm, parts per million; n/a, not applicable]

\begin{tabular}{llllccccc}
\hline \multicolumn{1}{c}{ Element } & Units & RL & $\mathbf{n}$ & $\begin{array}{c}\text { Target } \\
\text { value }\end{array}$ & Mean & $\begin{array}{c}\text { Standard } \\
\text { deviation }\end{array}$ & \% RSD & \% Recovery \\
\hline $\mathrm{Al}$ & $\%$ & 0.01 & 5 & 7.57 & 7.48 & 0.27 & 3.58 & 99 \\
$\mathrm{Ca}$ & $\%$ & 0.01 & 5 & 1.5 & 1.47 & 0.05 & 3.55 & 98 \\
$\mathrm{Fe}$ & $\%$ & 0.01 & 5 & 2.77 & 2.70 & 0.13 & 4.84 & 97 \\
$\mathrm{~K}$ & $\%$ & 0.01 & 5 & 4.25 & 4.30 & 0.20 & 4.57 & 101 \\
$\mathrm{Mg}$ & $\%$ & 0.01 & 5 & 0.615 & 0.59 & 0.02 & 3.81 & 96 \\
$\mathrm{Na}$ & $\%$ & 0.01 & 5 & 1.87 & 1.88 & 0.08 & 4.00 & 101 \\
$\mathrm{~S}$ & $\%$ & 0.01 & 5 & 0.074 & 0.07 & 0.00 & 6.62 & 100 \\
$\mathrm{Ti}$ & $\%$ & 0.01 & 5 & 0.339 & 0.33 & 0.02 & 6.46 & 99 \\
$\mathrm{As}$ & $\mathrm{ppm}$ & 1 & 5 & 31.4 & 31.2 & 2.04 & 6.54 & 99 \\
$\mathrm{Ba}$ & $\mathrm{ppm}$ & 5 & 5 & 1,310 & 1,343 & 37.8 & 2.81 & 103 \\
$\mathrm{Bi}$ & $\mathrm{ppm}$ & 0.04 & 5 & 4.28 & 4.21 & 0.17 & 4.12 & 98 \\
$\mathrm{Cd}$ & $\mathrm{ppm}$ & 0.1 & 5 & 0.227 & 0.22 & 0.04 & 18.1 & 97 \\
$\mathrm{Co}$ & $\mathrm{ppm}$ & 0.1 & 5 & 6.3 & 6.22 & 0.18 & 2.95 & 99 \\
$\mathrm{Cr}$ & $\mathrm{ppm}$ & 1 & 5 & 16.6 & 18.6 & 2.48 & 13.3 & 112 \\
$\mathrm{Cu}$ & $\mathrm{ppm}$ & 0.5 & 5 & 31.3 & 31.3 & 2.52 & 8.06 & 100 \\
$\mathrm{Ga}$ & $\mathrm{ppm}$ & 0.05 & 5 & 22.2 & 22.6 & 0.84 & 3.74 & 102 \\
$\mathrm{In}$ & $\mathrm{ppm}$ & 0.02 & 5 & 0.044 & 0.05 & 0.00 & 9.13 & 108 \\
$\mathrm{Li}$ & $\mathrm{ppm}$ & 1 & 5 & 34 & 32.7 & 1.51 & 4.61 & 96 \\
$\mathrm{Mn}$ & $\mathrm{ppm}$ & 5 & 5 & 281 & 270 & 10.3 & 3.81 & 96 \\
$\mathrm{Ni}$ & $\mathrm{ppm}$ & 0.5 & 5 & 11.5 & 9.48 & 1.05 & 11.1 & 82 \\
$\mathrm{P}$ & $\mathrm{ppm}$ & 50 & 5 & 1,230 & 1,228 & 29.3 & 2.38 & 100 \\
$\mathrm{~Pb}$ & $\mathrm{ppm}$ & 0.5 & 5 & 40.4 & 40.1 & 1.32 & 3.29 & 99 \\
$\mathrm{Rb}$ & $\mathrm{ppm}$ & 0.2 & 5 & 228 & 224 & 14.9 & 6.66 & 98 \\
$\mathrm{Sr}$ & $\mathrm{ppm}$ & 0.5 & 5 & 226 & 218 & 8.59 & 3.95 & 96 \\
$\mathrm{~V}$ & $\mathrm{ppm}$ & 1 & 5 & 73.3 & 78.1 & 3.55 & 4.55 & 106 \\
$\mathrm{Zn}$ & $\mathrm{ppm}$ & 1 & 5 & 117 & 114 & 4.82 & 4.23 & 97 \\
$\mathrm{Total} \mathrm{C}$ & $\%$ & 0.01 & 5 & $\mathrm{n} / \mathrm{a}$ & 0.20 & 0.00 & 2.26 & $\mathrm{n} / \mathrm{a}$ \\
$\mathrm{Carbonate} \mathrm{C}$ & $\%$ & 0.003 & 5 & $\mathrm{n} / \mathrm{a}$ & 0.32 & 0.01 & 3.44 & $\mathrm{n} / \mathrm{a}$ \\
\hline & & & & & & & &
\end{tabular}




\section{Reference Material USGS SAR-L}

Like USGS GSP-QC, the reference material SAR-L is not certified nor used outside of the U.S. Geological Survey. It is a composite of contaminated sediment from the Animas River watershed in Colorado with low levels of contaminant constituents. This material was developed in-house at the Denver USGS laboratories for inclusion with samples sent to the SGS laboratory. During the period of September 2004 to November 2008, this material was analyzed 360 times by the SGS laboratory for the ICP-AES/MS package as blind samples and 150 times for carbon. The results were compiled, and the means derived were used as target values for the accuracy assessments of this material submitted in this report. As a consequence, target values are available for all elements in the ICP-AES/MS package and for total and carbonate carbon.

The noncertified USGS reference material SAR-L was analyzed seven times along with the study samples. Table 2-8 gives the percent RSD and percent recovery results for this standard, and figure $2-8$ shows graphically the accuracy plot. All of the elements plot within \pm 15 percent for percent recovery.

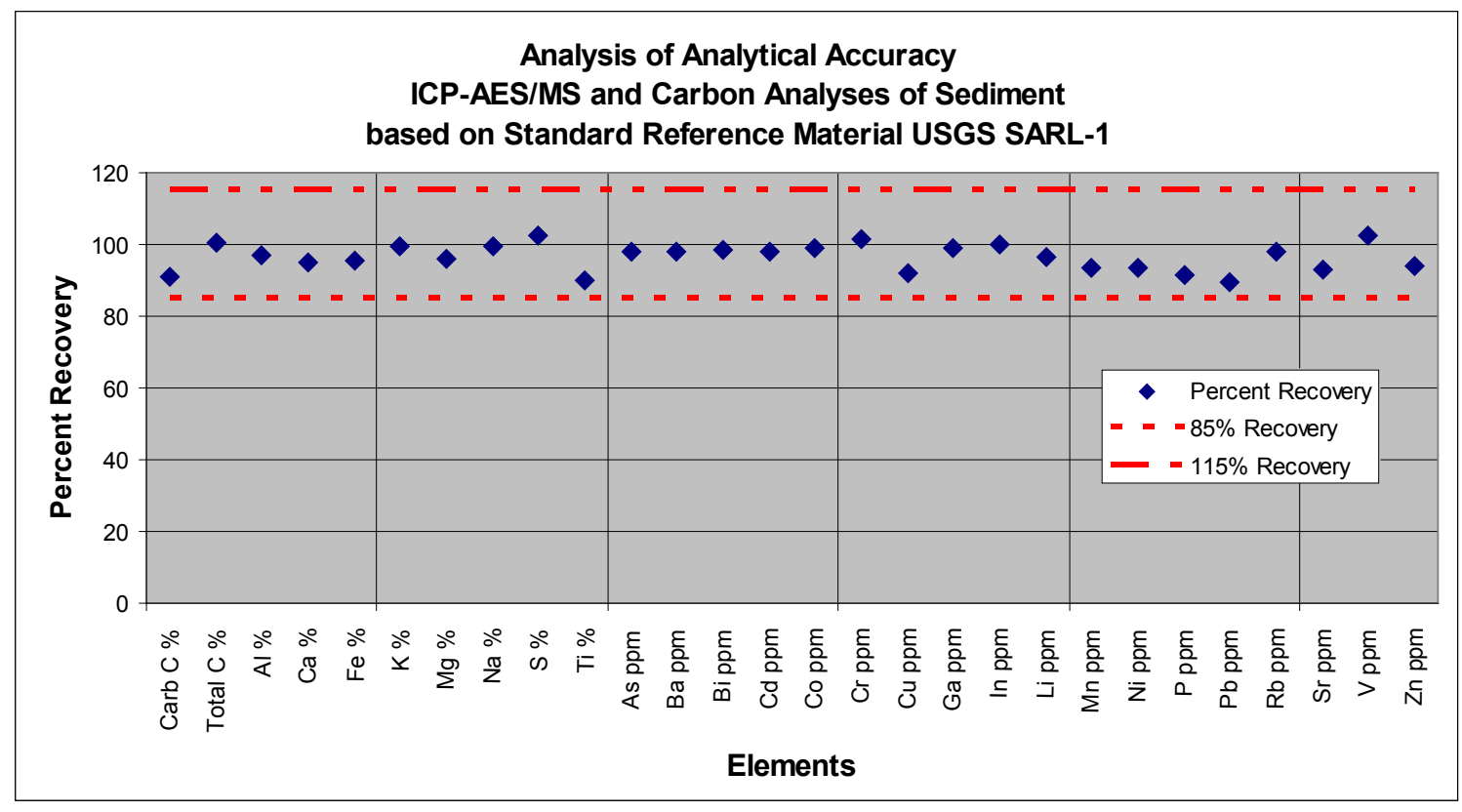

Figure 2-8. Accuracy plot for ICP-AES/MS and carbon analyses for reference material USGS SAR-L. [ICP-AES/MS, inductively coupled plasma-atomic emission spectroscopy/mass spectroscopy; USGS, U.S. Geological Survey; SAR-L, sediment, Animas River watershed, Colo., low levels of contaminants; \%, percent; ppm, parts per million] 
Table 2-8. Summary statistics for assessing analytical variation and accuracy for the reference material USGS SAR-L determined after a four-acid total digestion of sediment samples by the ICP-AES/MS package at SGS Minerals and for total and carbonate carbon. (Click to see Excel file.)

[USGS, U.S. Geological Survey; SAR-L, sediment, Animas River watershed, Colo., low levels of contaminants; ICPAES/MS, inductively coupled plasma-atomic emission spectroscopy/mass spectroscopy; RL, reporting limit; $n$, number of analyses of SAR-L; RSD, relative standard deviation; \%, percent; ppm, parts per million]

\begin{tabular}{llllccccc}
\hline \multicolumn{1}{c}{ Element } & Units & $\mathbf{R L}$ & $\mathbf{n}$ & $\begin{array}{c}\text { Target } \\
\text { value }\end{array}$ & Mean & $\begin{array}{c}\text { Standard } \\
\text { deviation }\end{array}$ & \% RSD & \% Recovery \\
\hline $\mathrm{Al}$ & $\%$ & 0.01 & 7 & 5.84 & 5.66 & 0.15 & 2.7 & 97 \\
$\mathrm{Ca}$ & $\%$ & 0.01 & 7 & 1.06 & 1.01 & 0.016 & 1.56 & 95 \\
$\mathrm{Fe}$ & $\%$ & 0.01 & 7 & 2.60 & 2.48 & 0.071 & 2.85 & 95 \\
$\mathrm{~K}$ & $\%$ & 0.01 & 7 & 3.02 & 3.01 & 0.084 & 2.78 & 100 \\
$\mathrm{Mg}$ & $\%$ & 0.01 & 7 & 0.54 & 0.514 & 0.014 & 2.72 & 96 \\
$\mathrm{Na}$ & $\%$ & 0.01 & 7 & 1.51 & 1.50 & 0.041 & 2.76 & 99 \\
$\mathrm{~S}$ & $\%$ & 0.01 & 7 & 0.08 & 0.080 & 0.000 & 0.00 & 103 \\
$\mathrm{Ti}$ & $\%$ & 0.01 & 7 & 0.23 & 0.207 & 0.0049 & 2.36 & 90 \\
$\mathrm{As}$ & $\mathrm{ppm}$ & 1 & 7 & 16.3 & 16.0 & 0.0 & 0.0 & 98 \\
$\mathrm{Ba}$ & $\mathrm{ppm}$ & 5 & 7 & 910 & 893 & 18.4 & 2.06 & 98 \\
$\mathrm{Bi}$ & $\mathrm{ppm}$ & 0.04 & 7 & 1.19 & 1.17 & 0.23 & 19.4 & 99 \\
$\mathrm{Cd}$ & $\mathrm{ppm}$ & 0.1 & 7 & 2.95 & 2.89 & 0.15 & 5.07 & 98 \\
$\mathrm{Co}$ & $\mathrm{ppm}$ & 0.1 & 7 & 7.14 & 7.09 & 0.27 & 3.77 & 99 \\
$\mathrm{Cr}$ & $\mathrm{ppm}$ & 1 & 7 & 96 & 97 & 3.9 & 4.01 & 101 \\
$\mathrm{Cu}$ & $\mathrm{ppm}$ & 0.5 & 7 & 386 & 356 & 14.8 & 4.16 & 92 \\
$\mathrm{Ga}$ & $\mathrm{ppm}$ & 0.05 & 7 & 16.5 & 16.4 & 0.72 & 4.39 & 99 \\
$\mathrm{In}$ & $\mathrm{ppm}$ & 0.02 & 7 & 0.30 & 0.30 & 0.01 & 3.83 & 100 \\
$\mathrm{Li}$ & $\mathrm{ppm}$ & 1 & 7 & 26.4 & 25 & 0.98 & 3.84 & 96 \\
$\mathrm{Mn}$ & $\mathrm{ppm}$ & 5 & 7 & 2,190 & 2,046 & 70.4 & 3.44 & 93 \\
$\mathrm{Ni}$ & $\mathrm{ppm}$ & 0.5 & 7 & 53 & 49.5 & 1.38 & 2.80 & 93 \\
$\mathrm{P}$ & $\mathrm{ppm}$ & 50 & 7 & 830 & 759 & 9.00 & 1.19 & 91 \\
$\mathrm{~Pb}$ & $\mathrm{ppm}$ & 0.5 & 7 & 589 & 527 & 22.5 & 4.27 & 89 \\
$\mathrm{Rb}$ & $\mathrm{ppm}$ & 0.2 & 7 & 140 & 137 & 6.61 & 4.82 & 98 \\
$\mathrm{Sr}$ & $\mathrm{ppm}$ & 0.5 & 7 & 156 & 145 & 2.89 & 1.99 & 93 \\
$\mathrm{~V}$ & $\mathrm{ppm}$ & 1 & 7 & 137 & 140 & 3.82 & 2.72 & 102 \\
$\mathrm{Zn}$ & $\mathrm{ppm}$ & 1 & 7 & 457 & 431 & 5.91 & 1.37 & 94 \\
$\mathrm{Total} \mathrm{C}$ & $\%$ & 0.01 & 7 & 1.06 & 1.07 & 0.01 & 0.89 & 101 \\
$\mathrm{Carbonate} \mathrm{C}$ & $\%$ & 0.003 & 7 & 0.11 & 0.01 & 0.0 & 0.0 & 91 \\
\hline & & & & & & & &
\end{tabular}




\section{Reference Material USGS SAR-M}

Like USGS GSP-QC and SAR-L, the reference material SAR-M is not certified nor used outside of the U.S. Geological Survey. It is a composite of contaminated sediment from the Animas River watershed in Colorado with moderate levels of contaminant constituents. This material was developed in-house at the Denver USGS laboratories for inclusion with samples sent to the SGS Minerals laboratory. During the period of September 2004 to November 2008, this material was analyzed 320 times by the contract laboratory for the ICP-AES/MS package as blind samples and 250 times for carbon. The results were compiled, and the means derived were used as target values for the accuracy assessments of this material submitted in this report. As a consequence, target values are available for all elements in the ICP-AES/MS package and for total and carbonate carbon.

The noncertified USGS reference material SAR-M was analyzed six times along with the study samples. Table 2-9 gives the percent RSD and percent recovery results for this standard, and figure 2-9 shows graphically the accuracy plot. All of the elements plot within \pm 15 percent for percent recovery, except for vanadium, which had a 170 percent recovery.

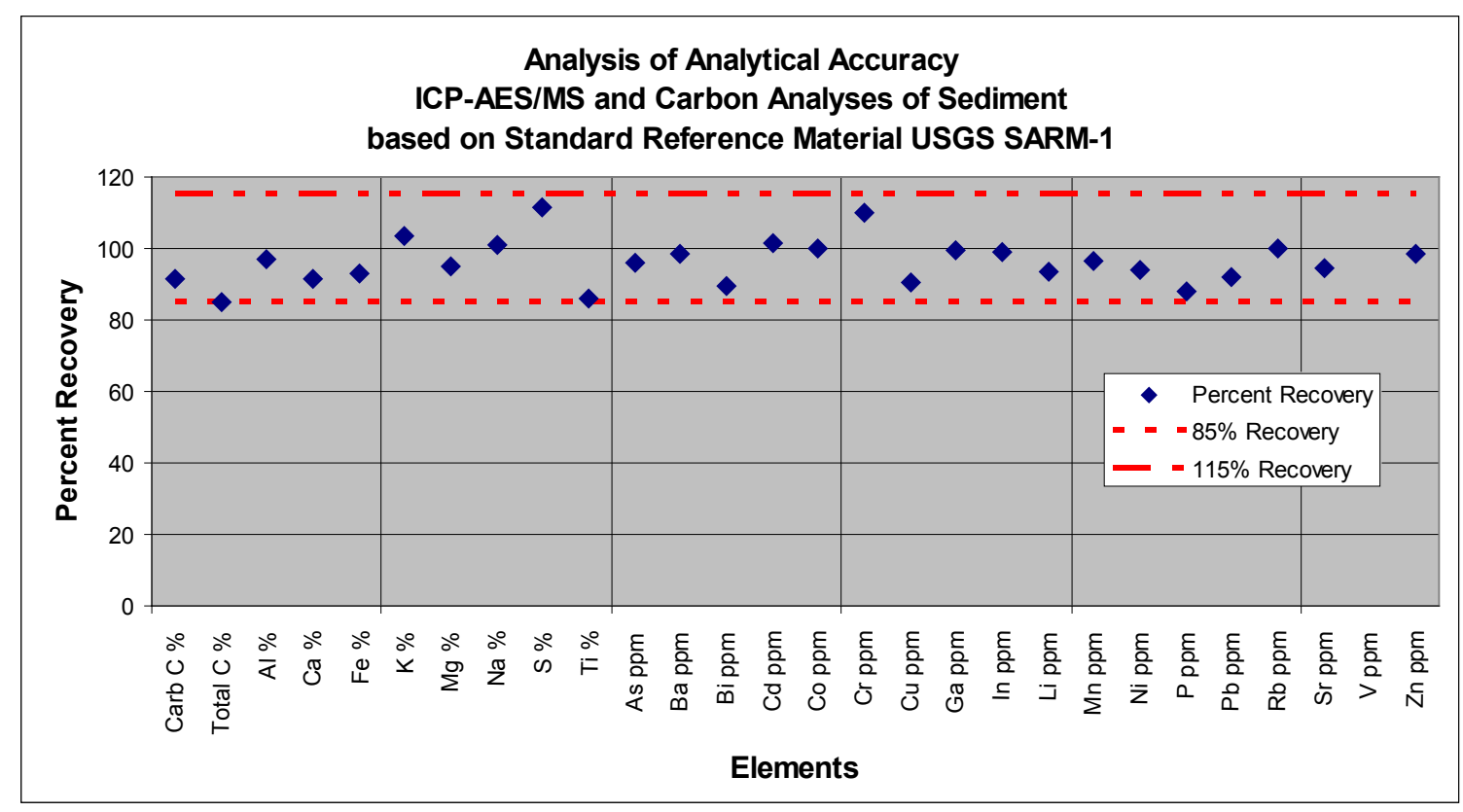

Figure 2-9. Accuracy plot for ICP-AES/MS and carbon analyses for reference material USGS SAR-M. [ICP-AES/MS, inductively coupled plasma-atomic emission spectroscopy/mass spectroscopy; USGS, U.S. Geological Survey; SAR-M, sediment, Animas River watershed, Colo., moderate levels of contaminants; \%, percent; ppm, parts per million] 
Table 2-9. Summary statistics for assessing analytical variation and accuracy for the reference material USGS SAR-M determined after a four-acid total digestion of sediment samples by the ICP-AES/MS package at SGS Minerals and for total and carbonate carbon. (Click to see Excel file.)

[USGS, U.S. Geological Survey; SAR-M, sediment, Animas River watershed, Colo., moderate levels of contaminants; ICPAES/MS, inductively coupled plasma-atomic emission spectroscopy/mass spectroscopy; RL,reporting limit; $n$, number of analyses of SAR-M; RSD, relative standard deviation; \%, percent; ppm, parts per million]

\begin{tabular}{llllccrrr}
\hline \multicolumn{1}{c}{ Element } & Units & $\mathbf{R L}$ & $\mathbf{n}$ & $\begin{array}{c}\text { Target } \\
\text { value }\end{array}$ & Mean & $\begin{array}{c}\text { Standard } \\
\text { deviation }\end{array}$ & \% RSD & \% Recovery \\
\hline $\mathrm{Al}$ & $\%$ & 0.01 & 6 & 6.13 & 5.94 & 0.10 & 1.7 & 97 \\
$\mathrm{Ca}$ & $\%$ & 0.01 & 6 & 0.587 & 0.55 & 0.02 & 3.75 & 93 \\
$\mathrm{Fe}$ & $\%$ & 0.01 & 6 & 3.1 & 2.92 & 0.09 & 3.14 & 94 \\
$\mathrm{~K}$ & $\%$ & 0.01 & 6 & 2.88 & 2.97 & 0.09 & 3.20 & 103 \\
$\mathrm{Mg}$ & $\%$ & 0.01 & 6 & 0.49 & 0.47 & 0.01 & 3.01 & 96 \\
$\mathrm{Na}$ & $\%$ & 0.01 & 6 & 1.16 & 1.17 & 0.02 & 1.67 & 101 \\
$\mathrm{~S}$ & $\%$ & 0.01 & 6 & 0.118 & 0.13 & 0.01 & 6.63 & 110 \\
$\mathrm{Ti}$ & $\%$ & 0.01 & 6 & 0.272 & 0.24 & 0.02 & 8.40 & 88 \\
$\mathrm{As}$ & $\mathrm{ppm}$ & 1 & 6 & 38.8 & 37.5 & 1.09 & 2.91 & 97 \\
$\mathrm{Ba}$ & $\mathrm{ppm}$ & 5 & 6 & 801 & 790 & 8.82 & 1.12 & 99 \\
$\mathrm{Bi}$ & $\mathrm{ppm}$ & 0.04 & 6 & 1.94 & 1.77 & 0.16 & 9.05 & 91 \\
$\mathrm{Cd}$ & $\mathrm{ppm}$ & 0.1 & 6 & 5.27 & 5.34 & 0.10 & 1.88 & 101 \\
$\mathrm{Co}$ & $\mathrm{ppm}$ & 0.1 & 6 & 10.7 & 10.7 & 0.28 & 2.59 & 100 \\
$\mathrm{Cr}$ & $\mathrm{ppm}$ & 1 & 6 & 79.7 & 86.6 & 4.15 & 4.79 & 109 \\
$\mathrm{Cu}$ & $\mathrm{ppm}$ & 0.5 & 6 & 331 & 304. & 15.9 & 5.23 & 92 \\
$\mathrm{Ga}$ & $\mathrm{ppm}$ & 0.05 & 6 & 16.8 & 16.7 & 0.95 & 5.70 & 99 \\
$\mathrm{In}$ & $\mathrm{ppm}$ & 0.02 & 6 & 1.08 & 1.07 & 0.04 & 3.35 & 99 \\
$\mathrm{Li}$ & $\mathrm{ppm}$ & 1 & 6 & 27.4 & 25.9 & 1.29 & 4.96 & 95 \\
$\mathrm{Mn}$ & $\mathrm{ppm}$ & 5 & 6 & 5,220 & 5,068 & 152 & 3.00 & 97 \\
$\mathrm{Ni}$ & $\mathrm{ppm}$ & 0.5 & 6 & 41.5 & 39.3 & 1.37 & 3.48 & 95 \\
$\mathrm{P}$ & $\mathrm{ppm}$ & 50 & 6 & 775 & 696 & 37.3 & 5.35 & 90 \\
$\mathrm{~Pb}$ & $\mathrm{ppm}$ & 0.5 & 6 & 982 & 915 & 42.4 & 4.64 & 93 \\
$\mathrm{Rb}$ & $\mathrm{ppm}$ & 0.2 & 6 & 146 & 146 & 6.04 & 4.14 & 100 \\
$\mathrm{Sr}$ & $\mathrm{ppm}$ & 0.5 & 6 & 151 & 144 & 3.32 & 2.30 & 95 \\
$\mathrm{~V}$ & $\mathrm{ppm}$ & 1 & 6 & 37.2 & 63.5 & 11.6 & 18.3 & 171 \\
$\mathrm{Zn}$ & $\mathrm{ppm}$ & 1 & 6 & 930 & 919 & 24.3 & 2.64 & 99 \\
$\mathrm{Total} \mathrm{C}$ & $\%$ & 0.01 & 6 & 0.35 & 0.30 & 0.03 & 9.46 & 87 \\
$\mathrm{Carbonate} \mathrm{C}$ & $\%$ & 0.003 & 6 & 0.13 & 0.13 & 0.02 & 15.4 & 100 \\
\hline & & & & & & & &
\end{tabular}

